\title{
SODIC-CALCIC FAMILY OF ALTERATION IN PORPHYRY SYSTEMS OF ARIZONA AND ADJACENT NEW MEXICO
}

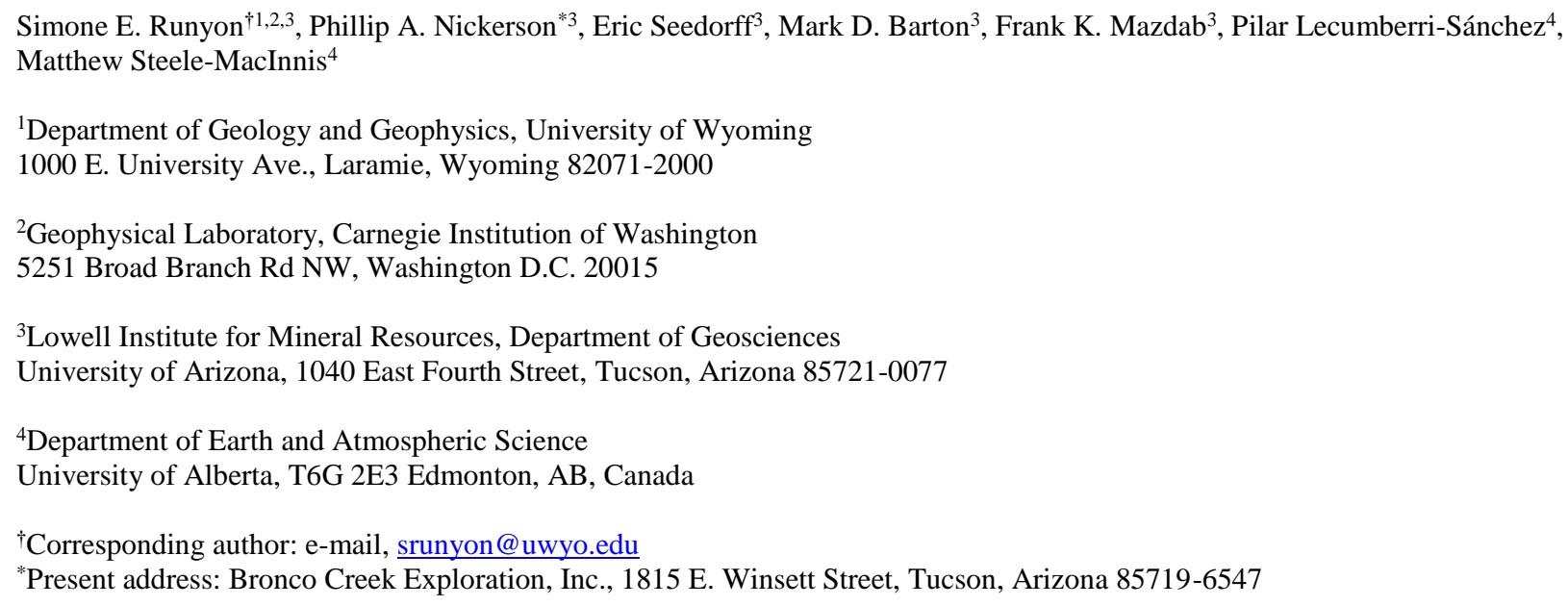


Abstract

Sodic-calcic alteration has affected numerous districts with Laramide porphyry systems

23 across Arizona and New Mexico. Previously undocumented Na-Ca alteration has been identified

24 at Charleston, Sycamore Canyon, Silver Bell, and the Ninetysix Hills in Arizona and the Central

25 mining district in New Mexico. These new occurrences are compared to sodic-calcic alteration at

26 the Sierrita-Esperanza deposit (Pima district), Ajo mining district, Tea Cup pluton (Kelvin-

27 Riverside district), and the Eagle Pass dike swarm in Arizona.

28 Spatial positions, crosscutting relationships, and mineral assemblages and compositions

29 allow for interpretation of the geochemical conditions of formation and implications for

30 associated hydrothermal processes. Diopside- or andradite-grossular solid solution $\left(\operatorname{Ad}_{68}-\mathrm{Ad}_{72}\right)$ -

31 stable assemblages representative of calcic alteration typically occur in deep and/or distal

32 positions but are less commonly exposed. The sodic-calcic and sodic alteration types, however,

33 occur more proximal to the porphyry orebody. Sodic-calcic assemblages containing Na-

34 plagioclase $\left(\mathrm{An}_{10}-\mathrm{An}_{33}\right)-\mathrm{Ca}-\mathrm{amphibole} \pm$ epidote are focused along granite cupolas near the

35 base of orebodies, and these grade into shallower sodic assemblages containing albite (An $00^{-}$

36 An 09 ) - epidote - chlorite. Mineral composition and fluid inclusion data suggest that $\mathrm{Na}-\mathrm{Ca}$

37 plagioclase-bearing assemblages form at higher temperatures $\left(360-470^{\circ} \mathrm{C}+\right)$ than later, lower

38 temperature albite - epidote assemblages $\left(>250^{\circ} \mathrm{C}\right)$. Calculated $\delta \mathrm{D}$ isotopic compositions of

39 fluids in equilibrium with $\mathrm{Na}-\mathrm{Ca}$ alteration minerals span a broad range ( -46 to $-1 \%$ ) and are

40 consistently less negative than magmatic fluids. Where members of the Na-Ca family of

41 alteration assemblages are present in porphyry systems, many lines of evidence — including

42 isotopic compositions of minerals and the geologic alteration zoning patterns - are consistent

43 with an origin by incursion of saline external fluids.

44 Where Na-Ca alteration is present, it is best developed at relatively deep levels of 
45 porphyry systems. Several Laramide systems that are well exposed at comparably deep levels

46 lack Na-Ca alteration, probably because sources of saline fluid were absent or hydrologic

47 conditions were unfavorable for the incursion of saline external fluids. Though similar in

48 temperatures, isotopic compositions, mineral assemblages, and zoning patterns, Na-Ca alteration

49 in Laramide systems is volumetrically smaller than in Jurassic systems documented in the

50 western United States, probably because saline external fluids were much less abundant during

51 the Laramide after a tectonically-driven excursion in paleoclimate from arid to humid conditions.

\section{Introduction}

53 Large volumes of sodic-calcic $(\mathrm{Na}-\mathrm{Ca})$ alteration are spatially and genetically associated

54 with iron oxide copper-gold (IOCG) systems, commonly focused along major faults and on the

55 flanks of intrusions that commonly lack porphyry textures and lack quartz veins and potassic

56 alteration, with compelling evidence for an external brine source for fluids at many deposits

57 (Williams et al., 2005; Barton, 2014). Porphyry systems, in contrast, contain broad patterns of

58 magmatic-hydrothermal alteration with potassic alteration and quartz veins and overlying

59 sericitic alteration, which generally are centered on small intrusions of porphyry, and there is a

60 first-order relationship in metal ratios and alteration mineralogy to the composition of the

61 associated porphyry intrusions (e.g., Gustafson, 1978; Burnham, 1979; Hedenquist and

62 Lowenstern, 1994; Seedorff et al., 2005a; Sillitoe, 2010). External fluids of varying origins and

63 salinities are also involved in hydrothermal alteration in many porphyry systems (Taylor, 1974,

64 1979; Osatenko and Jones, 1976; Bowman et al., 1987; Dilles et al., 1995; Seedorff et al., 2008).

65 Many tilted and dismembered porphyry systems in the Laramide arc have exposed root zones, a

66 few of which have reported Na-Ca alteration (Barton et al., 2005, 2007; Maher, 2008; Seedorff et

67 al., 2008). Where previously documented in porphyry systems, $\mathrm{Na}-\mathrm{Ca}$ alteration is commonly

68 deep or distal to the mineralizing porphyry intrusions or focused along the margins of earlier 
69 phases of a batholith, whereas variably developed iron oxide-rich alteration in porphyry districts

70 commonly is distal to and at shallower levels than the porphyry intrusions (Carten, 1986; Dilles

71 and Einaudi, 1992; Dilles et al., 2000; Barton et al., 2005; Runyon et al., 2015).

72 When developed broadly synchronous with formation of porphyry ores, Na-Ca alteration

73 typically postdates potassic alteration in any given cycle (Dilles et al., 1995; Seedorff et al.,

74 2008). Na-Ca alteration can significantly postdate porphyry mineralization and may have no

75 genetic relationship to a porphyry system (e.g., Cox et al., 2006; Nickerson et al., 2010). Na-Ca

76 alteration in these Laramide systems rarely affects $>1$ area percent of exposed altered rocks. Na-

77 Ca alteration is most voluminous in districts with evaporite-bearing Paleozoic strata, suggesting

78 that connate fluids derived from older sedimentary rocks and evaporites are major factors in the

79 formation of Na-Ca alteration around Laramide porphyry systems.

80 This study documents Na-Ca alteration in porphyry systems of Arizona and New Mexico,

81 with new geologic mapping, petrography, mineral analyses, hydrogen isotope analyses, and

82 whole-rock analyses. Previously documented occurrences of Na-Ca alteration provide context

83 for continued work at Sierrita-Esperanza and a basis of comparison for new work at Ajo,

84 Charleston, Sycamore Canyon, Silver Bell, and the Ninetysix Hills in Arizona and in the Central

85 mining district in New Mexico. These results are used to assess processes forming $\mathrm{Na}-\mathrm{Ca}$

86 alteration, are considered in the context of the broader Laramide porphyry systems, and are

87 compared with other Na-Ca alteration occurrences.

\section{Na-Ca Family of Alteration}

$89 \mathrm{Na}-\mathrm{Ca}$ alteration is characterized by the addition of $\mathrm{Ca} \pm \mathrm{Na}$, depletion of $\mathrm{K}$, and

90 common loss of Si (Barton et al., 1991; Battles and Barton, 1995; Barton, 2014). Na-Ca

91 alteration occurs in a wide range of host rocks. Though they may share certain minerals in

92 common with other alteration types (e.g., propylitic, intermediate argillic, and sericitic), the types 
93 of reactions and gains and losses of components are distinctive (e.g., Seedorff et al., 2005a).

\section{Distinction from propylitic alteration}

95 Minerals documented in $\mathrm{Na}-\mathrm{Ca}$ assemblages within this study are relatively common in

96 many forms of alteration. We emphasize the necessity of understanding protolith composition

97 and whole-rock analyses to distinguish $\mathrm{Na}-\mathrm{Ca}$ alteration from propylitic or sericitic alteration

98 (e.g., Titley, 1982; Agemar et al., 1999). Propylitic assemblages share some similarities with Na-

99 Ca alteration $\left(200-450^{\circ} \mathrm{C}, \delta \mathrm{D}-40\right.$ to $-70 \%$ ) and are interpreted to form either from the

100 circulation of dilute, external fluids (Sheppard et al., 1971; Sheppard and Gustafson, 1976;

101 Taylor, 1979; Bowman et al., 1987; Norman et al., 1991), from the mixing of meteoric and 102 magmatic fluids (e.g., Gustafson and Hunt, 1975), or in rare cases from the mixture of seawater 103 and magmatic fluids (e.g., Orovan et al., 2018).

Propylitic assemblages, as traditionally defined, are produced by volatile addition and do not involve major elemental addition or loss (Hemley and Jones, 1964; Meyer and Hemley, 1967, p. 175; Rose and Burt, 1979, p. 204; Seedorff, 1991, p. 379-383; Reed, 1997, p. 310-312; Muntean and Einaudi, 2000; Parry et al., 2002; Seedorff et al., 2005a). Though propylitic assemblages may contain minerals commonly found in sodic alteration (e.g., chlorite, epidote), proximal propylitic assemblages are generally K-feldspar stable. Hydrothermal mineral assemblages and whole-rock data show that elements (outside of certain volatiles) are not gained or lost during propylitic alteration (e.g., Norman et al., 1991; Dilles and Einaudi, 1992; Pirajno, 2009; Djouka-Fonkwé et al., 2012). Na-Ca alteration requires the addition of $\mathrm{Ca}$ and/or $\mathrm{Na}$, and the loss of $\mathrm{K}$, as documented by mineral assemblages (e.g., the common replacement of original K-feldspar by Na-plagioclase) and whole-rock analyses in this study. The presence of selected minerals that occur in $\mathrm{Na}-\mathrm{Ca}$ alteration alone are not indicative of $\mathrm{Na}-\mathrm{Ca}$ alteration; bulk chemical changes characterize the presence of $\mathrm{Na}-\mathrm{Ca}$ alteration. 


\section{Geologic Context}

Anorogenic granites (1.45-1.40 Ga) intruded the Pinal terrane $(\sim 1.65 \mathrm{Ga})$ under much of the study area (Anderson, 1989; Meijer, 2014). Proterozoic sedimentary rocks overly these metamorphic and intrusive units and are disconformably overlain by 1-2 km of Paleozoic strata, dominated by carbonate units that commonly contain evaporitic units (Shride, 1967; Beus, 1989; Wrucke, 1989; Bright et al., 2014). Laramide magmatism began in the Late Cretaceous ( 85 Ma) 123 and ended in the Eocene ( $45 \mathrm{Ma}$ ), with porphyry copper deposits mostly formed between 65 124 and $55 \mathrm{Ma}$ in southeastern Arizona and western New Mexico (Dickinson, 1989; Titley and 125 Anthony, 1989; Leveille and Stegen, 2012). Cretaceous volcanic rocks are commonly preserved 126 across southeastern Arizona, and Cretaceous sedimentary rocks in southern Arizona contain 127 evidence of deposition during a wet paleoclimate (e.g., Fort Crittenden Formation; Hayes, 1970; 128 Dettman, 1994).

129 Extension of the Laramide arc commenced in the Oligocene (Coney and Reynolds, 1977; 130 Dickinson, 1991, 2002; Nickerson et al., 2010; Nickerson and Seedorff, 2016). By the Miocene, 131 the average elevation of the southern Basin and Range province dropped, the climate became 132 more arid, and in Arizona thick evaporitic sequences developed within extensional basins 133 (Peirce, 1976; Eberly and Stanley, 1978). Extension and normal faulting dismembered many 134 porphyry copper deposits across Arizona (e.g., Lowell, 1968; Stavast et al., 2008; Nickerson and 135 Seedorff, 2016).

\section{Methods}

Alteration assemblages were mapped at a 1:6000 scale using a modified version of the 138 Anaconda method (Brimhall et al., 2006). Samples were analyzed on a Cameca SX100 electron 139 microprobe at the Michael J. Drake Electron Microprobe Laboratory at the University of 140 Arizona. Ostensibly unaltered hornblende and plagioclase analyzed for Al-in-hornblende 
141 thermobarometry were chosen based on spatial relationships and textures. Temperatures were

142 calculated using the Holland and Blundy (1994) method $\left( \pm 40^{\circ} \mathrm{C}\right)$. These temperatures were used

143 to calculate pressures ( \pm 0.6 kbar) using the method of Anderson and Smith (1995) and then

144 converted to depths using $1 \mathrm{~kb}=3.6 \mathrm{~km}$.

145 Fluid inclusions were analyzed in the context of petrographically identified assemblages

146 of coeval inclusions, using the textural criteria described by Goldstein and Reynolds (1994) to

147 classify assemblages in terms of timing relationships. For this, we carried out detailed

148 petrographic analysis of inclusions hosted primarily in epidote, as well as some inclusions hosted

149 in quartz. Microthermometry was conducted using a USGS-type heating/freezing stage mounted

150 on an Olympus BX53 microscope. Temperature in the stage was calibrated according to the

151 triple point of $\mathrm{CO}_{2}\left(-56.6{ }^{\circ} \mathrm{C}\right)$, the triple point of $\mathrm{H}_{2} \mathrm{O}\left(0.0^{\circ} \mathrm{C}\right)$, and the critical point of $\mathrm{H}_{2} \mathrm{O}$

$152\left(374.1^{\circ} \mathrm{C}\right)$ using synthetic fluid-inclusion standards. Precision and accuracy of the temperature

153 measurements are estimated to be $\pm 0.1^{\circ} \mathrm{C}$ at subzero temperatures and $\pm 0.5^{\circ} \mathrm{C}$ for temperatures

$154>100^{\circ} \mathrm{C}$. Salinities and pressure corrections were calculated using the program HoKIEFLINCS-

$155 \mathrm{H}_{2} \mathrm{O}-\mathrm{NACL}$ (Steele-MacInnis et al., 2012a).

156 Laser ablation ICP-MS analysis was conducted using a Thermo Element2 sector field

157 inductively coupled plasma mass spectrometer (ICPMS) connected to a Cetac $213 \mathrm{~nm}$ Nd-YAG

158 laser ablation system at the Lowell Institute for Mineral Resources. The NIST glass SRM 610

159 (Pearce et al., 1997) was used as the external standard and was analyzed to bracket every 10

160 analyses. Analyses consist of 40 seconds of background followed by 40 seconds of mineral

161 ablation at a $20-\mathrm{Hz}$ pulse rate using a 50-micron spot size. The data were processed using SILLS

162 software (Guillong et al., 2008). Raw counts-per-second data were converted to concentrations

163 using $\mathrm{SiO}_{2}$ concentration from EPMA analysis as the internal standard. Whole-rock data were 
164 processed by ALS Geochemistry using ICPMS and Inductively Coupled Plasma - Atomic 165 Emission Spectroscopy. Approximately 20-100g of material were provided for each sample.

166 Samples for isotope analysis were prepared by the Environmental Isotope Laboratory at 167 the University of Arizona. Hydrogen isotope compositions were measured on a Thermo Electron 168 Delta V continuous-flow gas-ratio mass spectrometer. Samples were combusted at $1375^{\circ} \mathrm{C}$ using 169 a ThermoQuest Finnigan Thermal combustion elemental analyzer coupled to the mass 170 spectrometer. Standardization is based on a linear calibration curve obtained by measuring three 171 materials: NIST SRM 8540 (-65.7\%o), IAEA CH7 (-110.3\%o), and an Environmental Isotope 172 Laboratory in-house standard benzoic acid (-87.6\%) in each set of analyses. Two-sigma 173 precision is better than \pm 2.5 per mil on the basis of repeated internal standards.

174 U-Pb age date samples were crushed and separated, with zircon grains mounted, 175 polished, and imaged with cathodoluminescence. U-Pb ages on igneous zircon were obtained by 176 laser ablation-inductively coupled plasma-mass spectrometry method at the University of 177 Arizona LaserChron Laboratory (Gehrels et al., 2008). Igneous zircon rims were analyzed to 178 obtain a robust age population for each sample (20-35 analyses).

\section{Sodic-Calcic Alteration in Laramide Porphyry Systems}

Tea Cup system, Kelvin-Riverside district, Arizona

The Tea Cup system is located in the Kelvin-Riverside district $\sim 96 \mathrm{~km}$ north-northwest

182 of Tucson (Schmidt, 1971; Zelinski, 1973; Corn and Ahern, 1994; Fig. 1). The Kelvin-Riverside 183 district contains the composite $\sim 72$ to $\sim 70$ Ma Tea Cup pluton (Barton et al., 2005; Seedorff et 184 al., 2005b; Nickerson et al., 2010). Each phase of the pluton developed a center of potassic 185 alteration. Deep-seated coarse muscovite alteration is present in western exposures of the system 186 in the youngest, two-mica granite phase.

187 Na-Ca alteration is developed 2-4 km outboard of the potassic alteration, from 6-8 $\mathrm{km}$ 
188

paleodepth (Table 1). Na-Ca alteration formed 3-mm to 2-cm wide veins at general density of 14 veins per meter. In areas of quartz leaching, local pockets of andradite-grossular solid solutionbearing $\mathrm{Na}-\mathrm{Ca}$ altered rocks are exposed over small areas $\left(\leq 0.01 \mathrm{~km}^{2}\right.$; Barton et al., 2005; Seedorff et al., 2008). Iron oxide-rich alteration is structurally higher, ranging from 2-4 km paleodepth (Nickerson et al., 2010). Na-Ca alteration may predate potassic alteration associated with the later intrusive phases of the system.

Ninetysix Hills, Arizona

The Ninetysix Hills are located 85 km north-northwest of Tucson (Fig. 1). The Box-O Ranch granodiorite may correlate to a U-Pb zircon date on a foliated granitoid that yielded an age of $75.8 \pm 2.3 \mathrm{Ma}$, though there may be multiple stocks within the dated unit (Yeend et al., 1977; Skotnicki, 1999; Spencer et al., 2003). The Box-O Ranch granodiorite is not associated with any currently known porphyry-style mineralization.

$\mathrm{Na}-\mathrm{Ca}$ alteration is exposed east and structurally shallower than the younger biotitemuscovite quartz monzonite (Bradfish, 1979; Skotnicki, 1999). Pervasive epidote-altered rocks formed along the western margins of the Box-O Ranch granodiorite (Bradfish, 1979). Albite epidote - chlorite veins with thin ( 1-3 mm) albite envelopes are present in eastern exposures of the Box-O Ranch granodiorite; veins are sparse (1-3 veins $/ \mathrm{m}$ ) and developed locally in zones of $\leq 300 \mathrm{~m}^{2}$ (Table 1). Minor calcite in the center of veins may postdate the epidote-albite 206 formation or may be an accessory mineral in the Na-Ca assemblage. Fractures filled with 207 hematite and minor secondary copper minerals cut younger Tertiary granite units in the 208 Ninetysix Hills (Skotnicki, 1999).

209 Central mining district, New Mexico 210 The Central mining district, located $20 \mathrm{~km}$ northeast of Silver City, New Mexico, is host 211 to a variety of mineral deposits (Jones et al., 1967; Hernon and Jones, 1968; Einaudi, 1982; 
212 Thoman et al., 2006; Fig. 1). The district contains several Laramide intrusive centers, including

213 the Hanover-Fierro granodiorite at the Continental mine (Hillesland et al., 1995; Duke, 2001).

214 The Hanover-Fierro stock intruded Paleozoic and Mesozoic sedimentary units, including the gypsum-bearing Yeso Formation, at 58.48 \pm 0.94 Ma (Jones et al., 1967; Mizer et al., 2015).

$\mathrm{Na}-\mathrm{Ca}$ alteration was documented early in the history of the Central mining district at the 217 Copper Flat stock (Lasky, 1936; Hernon and Jones, 1968). Albite - chlorite - epidote - calcite \pm 218 quartz wall-rock alteration was overprinted by minor sericite (Lasky, 1936). Localized Na-Ca 219 alteration assemblages are also present in the Hanover-Fierro stock as veins within the stock near intrusive contacts with Paleozoic sedimentary rocks. Na-Ca alteration along the western lobe of the Hanover-Fierro granodiorite formed sparse (1-2 veins/m) veins 3 to $8 \mathrm{~mm}$ wide (Table 1$)$. The Bessemer iron cuts and Jim Faire pit are magnetite- or hematite-dominated copper-bearing skarn or replacement bodies located in Paleozoic carbonate host rocks near the edge of the Hanover-Fierro stock.

Silver Bell system, Arizona

Silver Bell is located $56 \mathrm{~km}$ northwest of Tucson in the southern Silver Bell Mountains (Fig. 1). The Silver Bell mine contains quartz monzonitic stocks and associated $\sim 65 \mathrm{Ma}$ monzonite porphyry dikes intruding Paleozoic sedimentary rocks and Mesozoic sedimentary and volcanic strata (Richard and Courtright, 1966; Graybeal, 1982; Einaudi, 1982; Lopez and Titley, 1995; Mizer, 2018). Potassic alteration centered on quartz monzonite stocks was overprinted by weak sericitic alteration and peripheral propylitic alteration.

Near the contact of quartz monzonite porphyries with Paleozoic sedimentary rocks, quartz monzonite dikes are locally altered to hornblende - plagioclase - apatite with minor garnet 234 (Agenbroad, 1962). Na-plagioclase - diopside - actinolite overprinted weak potassic alteration 235 and was cut by an albite - epidote - chlorite \pm actinolite assemblage in the quartz monzonite 
stock and quartz monzonite to diorite porphyry dikes (Graybeal, 1982; Table 1).

Sierrita system, Pima district, Arizona

Sierrita-Esperanza is located $\sim 40 \mathrm{~km}$ southwest of Tucson on the eastern side of the Sierrita Mountains (Fig. 1). Porphyry mineralization at Sierrita-Esperanza is related to phases of the 64- to 58-Ma Ruby Star granodiorite, a composite pluton that intruded Proterozoic metamorphic and granitic rocks, Paleozoic sedimentary rocks, and Mesozoic sedimentary and volcanic rocks (Barter and Kelly, 1982; Einaudi, 1982; Jansen, 1982; West and Aiken, 1982; Herrmann, 2001; Aiken and Baugh, 2007; Stavast et al., 2008). The Sierrita porphyry system has been dismembered by normal faults and tilted $50-60^{\circ} \mathrm{S}$, exposing Laramide paleodepths of $\sim 1$ to $12 \mathrm{~km}$ (Stavast et al., 2007, 2008).

Na-Ca alteration accounts for $\sim 15 \%$ of altered rock exposed in the roots of the Sierrita 247 porphyry system (Cooper, 1960; Stavast, 2006). Na-Ca alteration is asymmetrically developed 248 along the eastern margin of the Ruby Star granodiorite where it intruded into evaporite-bearing 249 Paleozoic sedimentary rocks but is not developed on the western margin where it intruded an 250 older Cretaceous intrusion (Stavast, 2006; Stavast et al., 2007; Seedorff et al., 2008). Na-Ca 251 alteration associated with quartz leaching is exposed in deep $(4-8 \mathrm{~km})$, peripheral exposures that 252 grade into Ca-K veins (epidote - K-feldspar veins) towards the pit (Haynes and Titley, 1980; 253 West and Aiken, 1982; Preece and Beane, 1982; Stavast et al., 2008; Table 1). Na-Ca alteration 254 at Sierrita formed in multiple events after the emplacement of distinct phases of the Ruby Star 255 granodiorite, postdating potassic alteration in any given cycle (Stavast et al., 2007, 2008). 256 Sycamore Canyon system, Arizona

Sycamore Canyon is located $\sim 36 \mathrm{~km}$ southeast of Tucson, in the northwestern Santa Rita Mountains (Fig. 1). The 74-Ma Sycamore Canyon stock is composed of a quartz diorite, granodiorite, and quartz monzonite phases (Drewes, 1971; Runyon, 2017). Equigranular phases 
in the northwest and porphyritic phases to the southeast suggest that the system may be exposed at different levels, from deeper in the northwest to shallower in southeastern exposures, supported by tilting of local Paleozoic and Cretaceous sedimentary and volcanic strata $40-85^{\circ}$ to the east-southeast. Al-in-hornblende thermobarometry on the diorite yields a range of depths of emplacement; we interpret that the emplacement depth of the top of the diorite body is likely represented by the shallowest themobarometric result of $\sim 5.8 \pm 1.5 \mathrm{~km}$ (Runyon, 2017).

$\mathrm{Na}-\mathrm{Ca}$ alteration at Sycamore Canyon developed associated with albite - epidote chlorite veins that crosscut the stock (Fig. 2L-N). Minor calcite may be part of the $\mathrm{Na}-\mathrm{Ca}$ assemblage or may postdate the albite-epidote veins, as late calcite veins are common in the stock. Veins strike northwest $\left(281-350^{\circ}\right)$ and dip moderately $\left(49-69^{\circ}\right)$ northeast or strike northeast $\left(008-032^{\circ}\right)$ and dip moderately $\left(33-40^{\circ}\right)$ southeast. Veins are commonly $5 \mathrm{~mm}$ to 2.5 $\mathrm{cm}$ thick, abundances range from 1-5/m, and are reported over $\sim 1 \mathrm{~km}$ extent. Rare epidote veins with albite envelopes were apparently reopened and filled with coarse muscovite associated with late stage magmatic-hydrothermal alteration (Table 1).

\section{Charleston system, Arizona}

A Laramide pluton is exposed $15 \mathrm{~km}$ southwest of Tombstone, near the town of 276 Charleston (Fig. 1). Originally mapped as Schieffelin Granodiorite (Butler et al., 1938; Gilluly, 277 1945; Moore, 1993), this pluton has been more recently referred to as the quartz monzonite of 278 Brunckow Hill (Pearthree et al., 2006; Ferguson et al., 2009). Rare outcrops of a medium279 grained diorite are exposed close to the intrusive contact with Cretaceous andesite lava flows. A 280 fine- to medium-grained quartz monzonite appears to have intruded the $76 \mathrm{Ma}$ dioritic phase 281 (Runyon, 2017). This age suggests that the Brunckow Hill intrusion is a discrete intrusive phase 282 from the Schieffelin Granodiorite (U-Pb zircon 73.3 \pm 0.9 Ma; Mizer, 2018). The Brunckow 283 stock is not associated with any known porphyry-style mineralization. 
Albite - chlorite \pm tremolite veins cut the dioritic and quartz monzonitic phases of the Brunckow Hill intrusion within $\sim 1 \mathrm{~km}$ of the intrusive contact with the overlying Cretaceous volcanic units. Albite - chlorite \pm tremolite veins are sparse $(\sim 2 \mathrm{~mm}$ to $1 \mathrm{~cm}$ thick, from $1-3$ veins/m), comprising <1 area percent of an exposure. These veins display a range of orientations; the majority strike NE-SW $\left(030-066^{\circ}\right)$ and dip moderately to steeply north or south $\left(50-84^{\circ}\right)$. NaCa alteration observed at Charleston is dominated by albite veins \pm tremolite - actinolite envelopes and were overprinted by chlorite \pm minor calcite (Table 1).

\section{Mid-Cenozoic Examples}

Eagle Pass system, Klondyke district, Arizona

The 26.5-Ma Eagle Pass system is located in the Klondyke mining district $\sim 100 \mathrm{~km}$ northeast of Tucson on the western side of the Pinaleño Mountains (Davis and Hardy, 1981; Arca et al., 2010; Nickerson, 2012; Fig. 1). Potassic alteration developed in the dike swarm, extended into adjacent Proterozoic units, and predated Na-Ca alteration. Quartz-destructive NaCa alteration at Eagle Pass developed 3-6 km outboard from the potassic alteration and within a zone $\sim 1 \mathrm{~km}$ from and parallel to the Eagle Pass fault (Table 1). A zone of $\mathrm{Na}-\mathrm{Ca}$ alteration (chlorite - albite - hematite) is present in the footwall adjacent to the Eagle Pass fault. This intense sodic alteration along the fault zone may be a younger, extension-related alteration event. Mid-Cenozoic andesite lava flows in the hanging wall of the Eagle Pass fault are mostly unaltered but host sporadic specular hematite veins.

Ajo mining district, Arizona

The Ajo district is located in the Little Ajo Mountains, $200 \mathrm{~km}$ west of Tucson (Gilluly, 1942, 1946; Hagstrum et al., 1987; Cox et al., 2006; Wilkinson et al., 2010; Fig. 1). The porphyry copper system at the New Cornelia mine is related to the 68- to 69-Ma New Cornelia pluton (Runyon, 2017). West of the New Cornelia stock, in the footwall of the Gibson Arroyo 
309

310

fault, the 23.7-Ma Cardigan Peak pluton intruded Precambrian host rocks (Hagstrum et al., 1987; Cox et al., 2006). Sodic-calcic alteration overprinted the Cardigan Peak pluton in the footwall of the Gibson Arroyo fault. Sodic alteration also overprinted the porphyry copper system associated with the New Cornelia pluton in the hanging wall of the Gibson Arroyo fault and is documented here for comparison with porphyry-related systems (Cox and Ohta, 1984; Hagstrum et al., 1987; Cox et al., 2006; Table 1). There is no known porphyry-style mineralization associated with the Cardigan Peak intrusion. Nearby $\mathrm{Cu}$-rich specular hematite veins with chlorite envelopes cut mid-Cenozoic strata of the Locomotive Fanglomerate and commonly exploit mid-Cenozoic normal faults.

\section{Whole-Rock Analyses}

Whole-rock analyses were performed on least-altered and altered rock pairs to quantify mineralogic interpretations of elemental gains and losses (e.g., Meyer and Hemley, 1967) in order to gain insight into hydrothermal processes, which were calculated using the isocon method of Grant (1986; Table 2; Fig. 3A-C), following up on analogous work on sodic-calcic alteration in the Yerington district by Carten (1986) and Dilles et al. (1995). For the hydrothermal products studied and analyzed here, veins are volumetrically unimportant relative to adjacent wall-rock alteration, and the veins that are present exhibit textural evidence for an important replacement component. No whole-rock analyses were conducted solely of vein material. Least-altered samples were identified on the basis of preservation of igneous biotite \pm hornblende and twinning in feldspars, and lack of identifiable alteration minerals and lowertemperature, secondary minerals (e.g., chlorite and epidote).

All Na-Ca altered rocks analyzed show a gain of $\mathrm{Na}, \mathrm{Ca}$, or both and a loss of $\mathrm{K}$. Albite epidote - chlorite assemblages represented either a gain in $\mathrm{Na}$ (Charleston), increase in $\mathrm{Na}$ and $\mathrm{Ca}$ (Sycamore Canyon and Tea Cup), or Ca addition compared to unaltered host rock (Kelvin- 
Riverside and the Ninetysix Hills: Table 2). Oligoclase - andesine \pm actinolite \pm epidote assemblages from Sierrita represent increased Ca content, negligible change in Na, and loss of K. Sodic-calcic alteration either loses or conserves $\mathrm{Mg}$ and changes in Fe content are less consistent (Fig. 3A; Table 2). Rare earth element contents of Na-Ca altered rocks are not significantly different than those of unaltered host: highest $\Sigma$ REE contents are found in andradite-grossular solid solution-stable assemblages from Kelvin-Riverside, and the lowest $\Sigma$ REE contents are found in albite - epidote - chlorite wall-rock replacement from Sycamore Canyon.

$\mathrm{Na}-\mathrm{Ca}$ altered rocks from the Ajo mining district documented increased Na, no significant change of $\mathrm{Ca}$, and a loss of $\mathrm{K}$ (Cox et al., 2006). Estimation of major-element contents of samples from Eagle Pass suggested increased contents of $\mathrm{Na}$ and $\mathrm{Ca}$ and decreased $\mathrm{K}$ contents in albite - epidote - chlorite altered samples (Nickerson, 2012). Na-Ca alteration from Laramide systems shows more consistent gains in Ca relative to $\mathrm{Na}$, whereas the Cenozoic Na$\mathrm{Ca}$ alteration appears to show a more consistent gain in $\mathrm{Na}$.

\section{Mineral Compositions}

Three common Na-Ca assemblages were observed: 1) albite - epidote - chlorite \pm volumetrically minor actinolite assemblages that generally are rutile-stable, 2) oligoclase andesine - actinolite \pm epidote assemblages that generally are titanite-stable, and 3) diopside- or andradite-grossular solid solution-bearing oligoclase - andesine \pm actinolite \pm epidote assemblages that are generally titanite-stable. These assemblages span the $\mathrm{Na}, \mathrm{Na}-\mathrm{Ca}$, and $\mathrm{Ca}$ families of alteration as determined by whole-rock analyses: results are organized by hydrothermal mineral assemblage.

\section{Feldspars}

Hydrothermal feldspars in Na-Ca alteration formed inner or outer envelopes on veins, rarely formed within vein centerlines, and replaced original feldspars in wall-rock replacement. 
356 Plagioclase in plagioclase - epidote \pm chlorite veins and wall-rock replacement is Na-dominant

(Anoo to $\mathrm{An}_{14}$ : Charleston, Sycamore Canyon, and Ninetysix Hills; Fig. 4A; Table 3).

Plagioclase from plagioclase - Ca-amphibole \pm epidote \pm andradite-grossular solid solution \pm Capyroxene assemblages ranges from oligoclase to andesine in composition ( $\mathrm{An}_{10}$ to $\mathrm{An}_{37}$; Fig. 4A). Hydrothermal albite from albite - epidote - chlorite assemblages at Silver Bell, Sierrita, and the Central mining district contains lower $\mathrm{Sr}$ and Fe than hydrothermal oligoclase - andesine from Na-plagioclase - actinolite - epidote assemblages (Fig. 4A-B). Mid-Cenozoic examples of Na-Ca alteration contain Na-rich hydrothermal feldspars (Table 1 and 3).

\section{Chain silicates}

Many occurrences of albite - epidote - chlorite veins and wall-rock alteration lack hydrothermal amphibole and pyroxene. Albite - epidote veins with albite envelopes from Sycamore Canyon are an exception, as they contain volumetrically minor hydrothermal tschermakite to magnesiohornblende. Where observed, hydrothermal amphiboles and pyroxene replaced original mafic minerals and formed in vein centerlines and inner and outer envelopes. Ca-bearing amphibole and pyroxene from oligoclase - andesine \pm epidote assemblages include actinolite, tremolite, and diopside (Table 4, 5; Fig. 5A-B). Actinolite from Na-Ca alteration contains minor $\mathrm{Na}(0.09-0.2$ apfu) and 0.05 to 0.32 apfu $\mathrm{F}$ (Table 4; Fig. 5C). Amphibole in albite - chlorite - epidote assemblages has higher Mg\# than amphibole in oligoclase-andesinediopside assemblages in the Central mining district (Fig. 5A).

Garnet

Garnet formed veinlets and replaced igneous feldspars at Tea Cup in oligoclase - garnet epidote altered Ruin Granite (Table 5). Garnet compositions are andradite-rich $\left(\mathrm{Ad}_{68}-\mathrm{Ad}_{72}\right)$ and plot close to the andradite-grossular binary with only minor manganese (0.16-0.18 apfu) and titanium (0.06-0.08 apfu) contents. 


\section{Epidote-group minerals}

Epidote is observed in most $\mathrm{Na}-\mathrm{Ca}$ assemblages but was not present in oligoclase -

382 andesine - diopside - actinolite assemblages from Silver Bell and the Central mining district

383 (Table 6). Epidote-group minerals span a range of compositions, with minor Mn (0.01-0.04 apfu)

384 and relatively modest V contents (Fig. 6A-B). Epidote from albite - epidote - chlorite

385 assemblages has the greatest range in $\mathrm{V}$ contents and $\mathrm{Sr} / \mathrm{Ca}$ ratios (Fig. 6B). Epidote from $\mathrm{Na}-\mathrm{Ca}$

386 alteration contains a range of rare earth element contents (Table 6). Epidote in andradite-

387 grossular solid solution - oligoclase - epidote assemblages from Kelvin-Riverside are the most

388 enriched in $\mathrm{R}$ REE, and epidote in albite - epidote - chlorite veins from Sycamore Canyon has the 389 lowest $\Sigma$ REE (Table 6).

390 Oxides

$\mathrm{Na}-\mathrm{Ca}$ alteration hosted in magnetite-titanite stable intrusive bodies is generally weakly to pervasively magnetite-destructive. Hematite formed rare, $\sim 30 \mu \mathrm{m}$ to $2 \mathrm{~mm}$ specularite blades in albite - epidote - chlorite assemblages and replaced igneous magnetite in vein envelopes (e.g., Charleston, Sycamore Canyon, and Ninetysix Hills). Oligoclase - andesine - actinolite \pm diopside assemblages may be magnetite-destructive (e.g., Silver Bell and Tea Cup at KelvinRiverside) to magnetite-stable (e.g., Sierrita and Central mining district). Iron oxide-rich bodies are dominated by specular hematite in the Ninetysix Hills and the Kelvin-Riverside district, contain magnetite and hematite in the Central mining district (e.g., Jim Faire and Bessemer iron cuts), and are dominated by magnetite near Sierrita. Hematite-stable assemblages were observed in mid-Cenozoic Na-Ca alteration at Eagle Pass and Ajo.

\section{Sheet silicates}

Chlorite, commonly clinochlore with varying $\mathrm{Fe}$ content, is common in $\mathrm{Na}-\mathrm{Ca}$ assemblages (Runyon, 2017). Clinochlore appears to have formed in equilibrium with some 


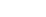

404 albite - epidote - chlorite assemblages and postdated certain $\mathrm{Na}-\mathrm{Ca}$ assemblages, observed as rims on actinolite or diopside. Fine-grained fluorian muscovite replaced minor amounts $(<20$ vol\%) of plagioclase along albite - epidote veins with albite - (relict) K-feldspar envelopes from the Ninetysix Hills. Apatite and titanite

Apatite is stable in all observed assemblages. Apatite commonly occurred with actinolite or diopside and dispersed as small grains in vein envelopes. Apatite is fluorine-bearing (0.4-1.0 $a p f u \mathrm{~F}$ ) and Cl-poor (commonly bdl-0.01 apfu Cl; Table 7). Albite - epidote - chlorite 412 assemblages are commonly rutile-stable, whereas oligoclase - andesine - actinolite assemblages 413 are commonly titanite-stable.

\section{Fluid Inclusions}

All fluid inclusions described here were determined to be either secondary (Goldstein and Reynolds, 1994) or of uncertain origin; no unequivocally primary inclusions were identified. Fluid inclusion assemblages were identified and characterized in both epidote and volumetrically minor quartz. Fluid inclusions from $\mathrm{Na}-\mathrm{Ca}$ alteration across all districts are dominated by highdensity, two-phase (liquid + vapor) or, less commonly, three-phase (liquid + vapor + daughter crystal) inclusions (Table 8; Fig. 7). Homogenization temperatures were pressure-corrected to 1600 bar ( $6 \mathrm{~km}$ paleodepth) based on previous structural reconstructions and thermobarometric data. Fluid inclusions from albite - epidote assemblages from the Ninetysix Hills yield estimated trapping temperatures of $250-290^{\circ} \mathrm{C}$, fluid inclusions in albite - epidote - tschermakite veins from Sycamore Canyon yield estimated trapping temperatures of $365^{\circ} \mathrm{C}+$, and fluid inclusions in oligoclase - actinolite - epidote assemblages from Sierrita yield estimated trapping temperatures between $360-470^{\circ} \mathrm{C}+$. Fluid inclusions in epidote and andradite-grossular solid solution in $\mathrm{Na}-\mathrm{Ca}$ altered Ruin granite from Kelvin-Riverside rarely froze at $-190^{\circ} \mathrm{C}$. 


\section{Hydrogen Isotopes}

Hydrogen isotopes were measured in epidote, chlorite, and amphibole from $\mathrm{Na}-\mathrm{Ca}$

assemblages (Table 9). Igneous biotite from across the districts yielded $\delta \mathrm{D}$ values between -59 to $-78 \%$. Epidote from albite - epidote - chlorite assemblages yielded $\delta \mathrm{D}$ values from -90 to $-74 \%$.

432 Compositions of minerals from oligoclase - andesine - epidote - actinolite assemblages range 433 from -74 to $-101 \%$ for epidote and -88 to $-95 \%$ for amphibole. Hydrogen isotopic composition 434 of epidote from a Na-plagioclase - andradite-grossular solid solution - epidote assemblage 435 yielded $-82 \%$. Late chlorite overprinting $\mathrm{Na}-\mathrm{Ca}$ alteration yielded the lowest $\delta \mathrm{D}$ values, from -95 436 to $-106 \%$. In each district, $\delta \mathrm{D}$ values of $\mathrm{Na}-\mathrm{Ca}$ minerals are consistently more negative than 437 those of igneous minerals.

447 stabilities and reflect pressure-corrected fluid inclusion trapping temperatures, though of 448 uncertain or secondary origin. Calculated $\delta \mathrm{D}$ values for fluids in equilibrium with chlorite and 449 epidote in albite - epidote - chlorite assemblages from Charleston and Silver Bell range from -39 450 to $-12 \%$. Calculated $\delta \mathrm{D}$ values for fluids in equilibrium with chlorite, epidote, and actinolite 451 from andesine - oligoclase - epidote - actinolite assemblages from Sierrita and Silver Bell range equilibrium with alteration assemblages using the fractionation equation of Chacko et al. (1999) for epidote and that of Suzuoki and Epstein (1976) for amphibole, chlorite, and biotite (Table 9). For the method of Suzuoki and Epstein (1976), $\delta D$ values of fluids in equilibrium with minerals were calculated using $\mathrm{Mg} / \mathrm{Fe}$ ratios estimated from electron microprobe composition data and temperatures estimated from mineral assemblages: $200^{\circ} \mathrm{C}$ for albite - epidote - chlorite alteration, $300^{\circ}$ for albite - actinolite \pm epidote assemblages, $400^{\circ} \mathrm{C}$ for oligoclase - andesine actinolite assemblages and $450^{\circ} \mathrm{C}$ for $\mathrm{Na}-\mathrm{Ca}$-plagioclase \pm andradite-grossular solid solution \pm diopside assemblages (Table 9). These temperatures fall within the lower range of the mineral from andesine - oligoclase - epidote - actinolite assemblages from Siemita and Silver Bell range 
from -39 to $-23 \%$. Calculated $\delta \mathrm{D}$ values for fluids in equilibrium with epidote from oligoclase andradite-grossular solid solution - epidote assemblages from Kelvin-Riverside yielded -46\%. Calculated fluids in equilibrium with Na-Ca minerals have distinctly less negative $\delta \mathrm{D}$ values than those in equilibrium with igneous minerals.

Calculated $\delta \mathrm{D}$ values for fluids in equilibrium with Mid-Cenozoic Na-Ca alteration minerals from Ajo show similar patterns: albite - epidote - chlorite assemblages yield -11 to $+12 \%$ and andesine - oligoclase - actinolite - epidote assemblages yield -27 to $-24 \%$.

\section{Discussion}

Whole-rock, mineral assemblage, and mineral composition zoning

In this study, albite - epidote \pm chlorite assemblages are commonly the shallowest form of $\mathrm{Na}-\mathrm{Ca}$ alteration but can extend to $\sim 8 \mathrm{~km}$ paleodepth (Kelvin-Riverside; Nickerson et al., 2010), may develop over a large $(\sim 3 \mathrm{~km})$ vertical distance, are more common and spatially extensive than other $\mathrm{Na}-\mathrm{Ca}$ assemblages, and may represent $\mathrm{Na}$ addition (Charleston), $\mathrm{Na}+\mathrm{Ca}$ addition (Sycamore Canyon), or Ca addition (Ninetysix Hills and Kelvin-Riverside). Oligoclase - andesine - actinolite \pm epidote assemblages range from distal to proximal in porphyry systems and formed at $\sim 4 \mathrm{~km}$ paleodepth from 360 to $470^{\circ} \mathrm{C}+$ at Sierrita (Stavast et al., 2008). Diopsideor andradite-bearing assemblages are commonly deep $\left(\sim 6-8 \mathrm{~km},>400^{\circ} \mathrm{C}\right.$; Kelvin-Riverside, Nickerson et al., 2010) and locally developed. In detail, these patterns are more complicated. Overlapping assemblages may reflect thermal collapse, structural dismemberment superimposing 471 alteration, and/or overprinting intrusions within a district.

$472 \quad$ Alteration assemblages in this study represent similar elemental changes but contain 473 fewer Ca-rich phases than Na-Ca alteration documented in previous studies (e.g., Dilles et al., 474 1995; Seedorff et al., 2005a, 2008). The fewer Ca-rich phases in Na-Ca alteration in Laramide 475 systems may result from fluids with higher Na activity or the external saline fluids may have 
contained lower $\mathrm{Ca}$, potentially a result of a less Ca-rich evaporitic unit or a scarcity of carbonates. Recirculation of magmatic fluids into the roots of a porphyry system would result in Ca-poor fluids, which may be partially responsible for small volumes of $\mathrm{Na}-\mathrm{Ca}$ alteration in the Laramide systems, but these fluids, even after formation of potassic alteration, would likely be quartz-saturated (e.g., Giggenbach, 1997; Seedorff et al., 2005, 2008; Sillitoe, 2010; Kouzmanov and Pokrovski, 2016).

$\mathrm{Na}-\mathrm{Ca}$ alteration assemblages in this study may represent differences in temperature and/or pressure (e.g., Carten, 1986; Dilles et al., 1992, 1995). Fluid inclusions in this study are similar in temperature and salinity to late, overprinting fluids in IOCG systems (Oreskes and Einaudi, 1992; Chen et al., 2010; Torresi et al., 2012). These fluid inclusions, likely superimposed on $\mathrm{Na}-\mathrm{Ca}$ forming fluids, broadly support lower temperature formation for albite epidote assemblages and higher temperatures for oligoclase - actinolite \pm epidote assemblages.

\section{Geochemical environments and fluid evolution}

Districts in this study fit the general evolution of $\mathrm{Na}-\mathrm{Ca}$ fluids, with $\mathrm{Na}-\mathrm{Ca}$ rich fluids drawn towards a porphyry system, fixing $\mathrm{Na}+\mathrm{Ca}$ and putting $\mathrm{Si}+\mathrm{K}$ into solution along a warming path, as silica solubility increases with increasing temperature and $\mathrm{NaCl}$ fluid content (Fig. 8B; Carten, 1986; Dilles et al., 1995; Barton and Johnson, 1996). In deep Na-Ca alteration at Sierrita and Kelvin-Riverside, quartz is leached from host rock and whole-rock analyses of $494 \mathrm{Na}-\mathrm{Ca}$ alteration show a loss of $\mathrm{SiO}_{2}$ (Fig. 2C-E, J-K; 3A). Magmatic-hydrothermal fluids may 495 intersect retrograde temperature-dependent quartz solubility at low pressures, but timing and 496 spatial relationships and $\mathrm{Na}-\mathrm{Ca}$ dominant cation loads suggest that the $\mathrm{Na}-\mathrm{Ca}$ forming fluids are 497 not sourced from a hydrous magma (Akinfiev and Diamond, 2009; Steele-MacInnis et al., 498 2012b). Na-Ca fluids reach a 'turning point' of maximum temperature and begin outflow / 499 upflow and cooling (e.g., Cathles, 1977, 1990; Hanson, 1996; Fournier, 1999). At lower 
temperatures and with low $\mathrm{a}_{\mathrm{K}+\mathrm{H}+}$, the fluids become acidic (e.g., Dilles et al., 1995; Kreiner and Barton, 2017). Na-Ca fluids in Laramide systems put Fe into solution at higher temperatures and commonly precipitate Fe oxide-rich mineralization at lower temperatures $\left(<400^{\circ} \mathrm{C}\right.$; Sierrita and Tea Cup). These patterns likely represent the evolution of a high-Cl fluid capable of transporting significant $\mathrm{Fe}$ at high temperatures.

\section{Na-Ca forming fluids}

Fluid inclusions analyzed were of secondary or uncertain origin, so their significance 507 must be viewed cautiously and their relationship to Na-Ca forming fluids is unclear. Estimated 508 trapping temperatures range from $250-290{ }^{\circ} \mathrm{C}$ for albite - epidote assemblages to $360-470{ }^{\circ} \mathrm{C}$ for 509 oligoclase - actinolite - epidote assemblages. These temperatures are broadly consistent with 510 mineral equilibria estimates (Table 8). In geothermal settings, epidote is stable to $170{ }^{\circ} \mathrm{C}$ (Liou et 511 al., 1985) and is a common phase between $200-250{ }^{\circ} \mathrm{C}$ (Seki, 1972), and actinolite represents 512 minimum temperatures of $280-340{ }^{\circ} \mathrm{C}$ (Reyes, 1990). Temperatures from fluid inclusions are 513 consistent with phase equilibrium constraints, though they may represent minimum temperatures. 514 Fluid inclusion salinities range up to $\sim 15 \mathrm{wt} \% \mathrm{NaCl}$ (Table 8), which would be fairly 515 typical of basinal fluids (Yardley, 2005). Fluid inclusions in andradite at Tea Cup in Kelvin516 Riverside rarely froze at $-190^{\circ} \mathrm{C}$ : this may indicate low eutectic temperatures resulting from high 517 contents of $\mathrm{CaCl}_{2}$ in fluid inclusions (e.g., Baumgartner and Bakker, 2009) and/or salinities of 25 518 to $35 \mathrm{wt} \%$ equivalent (Bodnar et al., 2014). High $\mathrm{CaCl}_{2}$ contents are atypical of magmatic519 hydrothermal fluids in porphyry systems (Bodnar et al., 2014) but are typical of basinal fluids 520 (Yardley, 2005). Isotopic $\delta \mathrm{D}$ values of Na-Ca minerals are consistently more negative than those 521 of igneous minerals, and calculated fluids in equilibrium with $\mathrm{Na}-\mathrm{Ca}$ minerals have less negative $522 \delta \mathrm{D}$ values than those in equilibrium with igneous minerals (Table 9 ); $\delta \mathrm{D}$-enriched fluid sources 523 suggest $\mathrm{Na}-\mathrm{Ca}$ alteration forms from non-magmatic fluids in Laramide porphyry systems. 
524

6

7525

8

Mass balance alone does not preclude the involvement of recirculated magmatic hydrothermal fluids in the formation of the Na-Ca alteration. Albitization in W-Sn deposits results from magmatic-hydrothermal fluids with high $\mathrm{Na} / \mathrm{K}$ ratios following potassic alteration (e.g., Heinrich, 1990). Na-Ca alteration in this study is distinct in that it commonly forms beneath ore zones, postdates porphyry mineralization, and has distinct $\delta \mathrm{D}$ compositions from magmatic-hydrothermal fluids. System-scale zoning patterns, mass balance, temporal relationships, and hydrogen isotopic compositions of $\mathrm{Na}-\mathrm{Ca}$ alteration minerals show distinct compositions from magmatic signatures, suggesting that $\mathrm{Na}-\mathrm{Ca}$ alteration formed from the circulation of saline, non-magmatic fluids (Fig. 9).

Evaporitic brines are a commonly proposed fluid source for $\mathrm{Na}-\mathrm{Ca}$ alteration along the Jurassic arc in the western United States (e.g., Battles and Barton, 1995; Dilles et al., 1992, 1995; Seedorff et al., 2008). Paleozoic sedimentary \pm evaporite units present near Laramide intrusions, such as gypsum ( \pm anhydrite) beds in the Colina Limestone (Bulter, 1971), minor gypsum ( \pm anhydrite) beds in the Epitaph Formation (Butler, 1971; Blakey and Knepp, 1989), and gypsumand halite-dominated beds in the Supai Formation (Rauzi, 2000), may have provided fluids for $\mathrm{Na}-\mathrm{Ca}$ alteration formation. The most extensive Laramide $\mathrm{Na}-\mathrm{Ca}$ alteration occurs adjacent to Paleozoic sedimentary sections that commonly contain evaporitic units (e.g., Sierrita, Silver Bell, and Sycamore Canyon; Wilson, 1962; Peirce and Gerrard, 1966; Stavast et al., 2008).

Arizona's relatively wet paleoclimate during development of the Laramide arc likely 543 resulted in dilute groundwater (Hayes, 1970; Dettman, 1994), the circulation of which commonly forms propylitic alteration (Sheppard et al., 1971; Sheppard and Gustafson, 1976; Taylor, 1979; Bowman et al., 1987) that is well documented in Laramide porphyry systems (e.g., Christmas, Koski and Cook, 1982; Silver Bell, Graybeal, 1982). Calculated $\delta$ D values of Na-Ca-forming 
547 fluids are similar to $\delta \mathrm{D}$ values of basinal brines or connate fluids sourced from nearby Paleozoic sedimentary strata (Sheppard, 1986). The paleogeography and tectonics of southwestern North America changed in the Cretaceous and early Cenozoic (e.g., Dickinson, 1989, 2004), resulting in shifts in the paleoclimate from hot and arid in the Jurassic to hot and humid in the Laramide (Peirce, 1976; Eberly and Stanley, 1978; Dettman, 1994). This shift in paleoclimate likely resulted in a decrease in the availability of saline fluids and weaker development of $\mathrm{Na}-\mathrm{Ca}$ alteration during the Laramide than during the Jurassic.

\section{Timing of sodic-calcic alteration}

Crosscutting relationships indicate that $\mathrm{Na}-\mathrm{Ca}$ alteration formed broadly synchronous with but after potassic alteration in Laramide plutons (e.g., Sierrita, Silver Bell, and Tea Cup), with magma providing energy for thermal convection (e.g., Hanson et al., 1993; Dilles et al., 1995). Na-Ca forming fluids circulated into the system following the initial expulsion of magmatic-hydrothermal fluids and postdating the peak thermal gradients. Duration of $\mathrm{Na}-\mathrm{Ca}$ alteration may be limited by 1) the time required for cooling of a pluton, in which case the timescale is directly related to the dimensions of a given intrusion or 2) the rate of thermal relaxation along an extensional fault, in which case long-lived convection systems may be established if fluid flow represents a thermal flux that is less than the local geothermal gradient.

\section{$\mathrm{Na}$-Ca alteration in porphyry systems in Arizona and globally}

Other Laramide porphyry copper systems that have reported associated $\mathrm{Na}-\mathrm{Ca}$ alteration 566 include early albite replacement of plagioclase at Bagdad (Anderson et al., 1955), Christmas 567 (Koski and Cook, 1982), Lakeshore/Tohono (Huyck, 1990), Miami (Ransome, 1919), Santa Rita 568 (Leveille and Stegen, 2012), and Twin Buttes (Leveille and Stegen, 2012). Albite - epidote \pm 569 specularite or magnetite veins are observed in Laramide stocks at Lakeshore/Tohono, Christmas, Dos Pobres, Lone Star, Tyrone, and Morenci (Leveille and Stegen, 2012). Na-Ca alteration and 
571 Fe oxide-rich mineralization are relatively common in the Laramide of central and southern Mexico (e.g., Zurcher, 2002). Na-Ca alteration has been documented in Triassic to Eocene porphyry systems at Battle Mountain, Yerington, Pine Grove, Royston, Lights Creek, Cuddy Mountain, Pebble, Copper Mountain-Ingerbelle, and Island Copper porphyry systems (Dilles et al., 1995; Barton et al., 2011; Gregory, 2017; King, 2017). Examples of Na-Ca alteration in western North America span from Triassic to Miocene; variation in host rock and age suggests that $\mathrm{Na}-\mathrm{Ca}$ alteration forms readily in many different environments. We might expect more reports of $\mathrm{Na}-\mathrm{Ca}$ alteration in porphyry systems where deeper portions of porphyry systems were emplaced near coeval or older evaporite occurrences or near saline basinal fluids.

\section{Implications for Exploration}

All porphyry systems emplaced in the upper crust might be variably composite, with essential magmatic-hydrothermal fluids dominating early advective stages of fluid flow and distal regions altered by dominantly external fluids as magmatic bodies crystallize (e.g., Seedorff et al., 2005a, 2008). In the case of Laramide porphyry systems, external fluids could be basinal waters, formation waters, or surface fluids that undergo subsequent compositional changes as they interact with wall rocks. Na-Ca alteration should form wherever heat sources are present in sedimentary-volcanic sections containing saline fluids, so long as sufficient permeability is available. Where $\mathrm{Na}-\mathrm{Ca}$ alteration is present in porphyry districts, one cannot assume that $\mathrm{Na}-\mathrm{Ca}$ alteration necessarily formed contemporaneously with magmatic-hydrothermal portions of the system (Hagstrum et al., 1987; Cox et al., 2006; Runyon, 2017) or with late emplacement of 591 porphyry dikes as opposed to earlier phases of a batholith (e.g., Runyon et al., 2015). Where 592 alteration generated by external fluids forms broadly concurrent with products of magmatic593 hydrothermal alteration, as in many of the Laramide examples described here, the spatial distribution of distal hydrothermal alteration can be used as a vector toward the center of the 
system. Origins of distal alteration types at each porphyry system must be judged on their geologic and geochemical merits, and each system should be explored accordingly.

\section{Conclusions}

$\mathrm{Na}-\mathrm{Ca}$ alteration is newly documented at Ninetysix Hills, Silver Bell, Sycamore Canyon, and Charleston, and better documented at the Ajo, Sierrita, Central mining district, and Tea Cup systems. These systems range in age from Laramide through Miocene and contain a variety of $\mathrm{Na}-\mathrm{Ca}$ alteration styles. Where $\mathrm{Na}-\mathrm{Ca}$ alteration is present, albite $\left(\mathrm{An}_{00}-\mathrm{An}_{09}\right)-$ epidote chlorite alteration is commonly proximal to distal to the porphyry orebody, forms shallower and at lower temperatures than Na-plagioclase $\left(\mathrm{An}_{10}-\mathrm{An}_{33}\right)$ - Ca-amphibole \pm epidote alteration within a given district. Less common diopside- or andradite-grossular solid solution-stable assemblages are typically deep and/or distal.

The magmatic-hydrothermal portions of porphyry systems (e.g., typified by potassic and 607 sericitic types of alteration) exhibit differences in alteration mineralogy and metal ratios that 608 have a first-order correlation to compositions of mineralizing intrusions; the alteration patterns of 609 the magmatic-hydrothermal portions of porphyry systems point downward toward the apices of 610 mineralizing intrusions; and the isotopic evidence points toward a source dominated by 611 hydrothermal fluids of magmatic origin (e.g., Seedorff et al., 2005a). Where present, the 612 alteration patterns of $\mathrm{Na}-\mathrm{Ca}$ alteration types, as best illustrated for the Jurassic arc in the 613 Yerington district and for the Laramide arc in the Pima district (Sierrita), point outward toward 614 preexisting evaporitic source beds or outward and upward toward contemporaneous saline 615 surface waters. Moreover, calculated $\delta \mathrm{D}$ isotopic compositions of fluids in equilibrium with Na616 Ca alteration minerals are consistently less negative than magmatic fluids and span a broad range 617 (-46 to -1\%o). Spatial, temporal, mass balance, and isotopic evidence indicates that $\mathrm{Na}-\mathrm{Ca}$ 618 alteration formed by convective flow of non-magmatic, saline external fluids, including after 
7

8

each major cycle of expulsion of magmatic-hydrothermal fluids from mineralizing porphyry intrusions.

Nonetheless, $\mathrm{Na}-\mathrm{Ca}$ alteration appears to be absent in certain districts, even where midCenozoic extension has afforded exposures to deep paleodepths (e.g., Ray and Globe-Miami, Arizona). The lack of Na-Ca alteration in these districts may be due to adverse hydrologic conditions preventing the incursion of saline fluids into a porphyry system or to a general absence of external saline fluids, with long-lived expulsion of magmatic-hydrothermal fluids creating late-stage alteration deep in the root zones of the systems (e.g., Seedorff et al., 2008; Runyon, 2017). Except for the Laramide Sierrita system and the partial superposition of Miocene sodic-calcic alteration on the Laramide Ajo porphyry system, districts with $\mathrm{Na}-\mathrm{Ca}$ alteration contain minor volumes of $\mathrm{Na}-\mathrm{Ca}$ alteration, rarely achieving 1 area percent of exposed altered rocks (e.g., Cox et al., 2006; Stavast et al., 2008). Laramide external fluids were volumetrically and/or compositionally distinct from external fluids available along the Jurassic arc across southwestern North America, probably due to a tectonically-driven shift in paleoclimate from arid in the Jurassic to humid in the Laramide, followed by a return to arid by the mid-Cenozoic. The anomalously strong development of Na-Ca alteration during the Laramide asymmetrically on the deep eastern flank at Sierrita can be attributed to proximity to a preexisting evaporite beds (Stavast et al, 2008), whereas at Ajo intense $\mathrm{Na}-\mathrm{Ca}$ alteration was made possible by a return to arid conditions by Miocene time when nearby evaporite basins were forming (Cox et al., 2006).

To some degree, all hydrothermal systems have both external and inherent magmatichydrothermal features, although the degree to which the external fluids transport metals is not always recognized (Barton and Johnson, 1996). Multiple factors influence the development, intensity, and geometry of $\mathrm{Na}-\mathrm{Ca}$ alteration associated with Laramide systems in Arizona, 
including wall-rock composition, external fluid composition, amount of fluids available, and the amount of heat available to circulate fluids. Each scenario should have distinct stable isotopic signatures and position and ages relative to the porphyry system. Such variations on the theme of incursion of external fluids should be considered in evaluating the potential role of nonmagmatic fluids in any specific porphyry deposit or prospect.

\section{Acknowledgments}

We greatly appreciate comments from David Cooke, Mark Reed, and an anonymous reviewer. RA support came from industry gifts in support of the Lowell Program in Economic Geology. Additional support was provided by the Geological Society of America and the Society of Economic Geologists. We appreciate assistance, access, helpful discussion, and samples from the following individuals and organizations: Kevin Byrne, Aryn Hoge, Adam Gorecki, Jerome Lambiotte, Cody-John Davis, William J. A. Stavast, Tyler L. Vandruff, Erik Flesch, Eric Jensen, J.D. Mizer, Ken Domanik, Chris Brus, Lucia Profeta, Carson Richardson, Brad Johnson, Freeport McMoRan, and ASARCO. The Lowell Institute for Mineral Resources provided support for LA-ICP-MS analyses.

\section{References}

Agemar, T., Worner, G., and Heumann, A., 1999, Stable isotopes and amphibole chemistry on hydrothermally altered granitoids in the North Chilean Precordillera: A limited role for meteoric water?: Contributions to Mineralogy and Petrology, v. 136, p. 331-344.

Agenbroad, L.D., 1962, The geology of the Atlas mine area, Pima County, Arizona: Unpublished M.S. thesis, Tucson, University of Arizona, $39 \mathrm{p}$.

Aiken, D.M., and Baugh, G.A., 2007, The Sierrita copper-molybdenum deposit: An updated report Pima Mining District, Pima County, AZ: in, Graybeal, F., ed., Porphyry copper systems of southern Arizona, Arizona Geological Society, Ores and Orogenesis Symposium, Tucson, Arizona, Guidebook No. 8, p. 1-46.

Akinfiev, N.N., and Diamond, L.W., 2009, A simple predictive model of quartz solubility in water-salt- $\mathrm{CO}_{2}$ systems at temperatures up to $1000^{\circ} \mathrm{C}$ and pressures up to $1000 \mathrm{MPa}$ : Geochimicae et Cosmochimica Acta, v. 73, p. 1597-1608.

Anderson, C.A., Scholz, E.A., and Strobell, J.D., Jr., 1955, Geology and ore deposits of the Bagdad area, Yavapai County Arizona: U.S. Geological Survey Professional Paper 278, 103 p. 
Anderson, J.L., 1989, Proterozoic anorogenic granites of the southwestern United States: Arizona Geological Society Digest 17, p. 485-514.

Anderson, J.L., and Smith, D.R., 1995, The effects of temperature and fo2 on the Al-inhornblende barometer: American Mineralogist, v. 80, p. 549-559.

Arca, M.S., Kapp, P., and Johnson, R.A., 2010, Cenozoic crustal extension in southeastern Arizona and implications for models of core-complex development: Tectonophysics, v. 488, p. 174-190.

Barter, C.F., and Kelly, J.L., 1982, Geology of the Twin Buttes mineral deposit, Pima mining district, Pima County, Arizona, in Titley, S.R., ed., Advances in geology of the porphyry copper deposits, southwestern North America: Tucson, University of Arizona Press, p. 353374.

Barton, M.D., 2014, Iron oxide(-Cu-Au-REE-P-Ag-U-Co) systems, in Scott, S.D., ed., Ore Deposits, 2nd Edition, Treatise on Geochemistry, Volume 13: Oxford, Elsevier, p. 515-541.

Barton, M.D., and Johnson, D.A., 1996, Evaporitic-source model for igneous-related Fe oxide(REE-Cu-Au-U) mineralization: Geology, v. 24, p. 259-262.

Barton, M.D., Ilchik, R.P., and Marikos, M.A., 1991, Metasomatism, in Kerrick, D.M., ed., Contact metamorphism: Mineralogical Society of America Reviews in Mineralogy, v. 26, p. 321-350.

Barton, M.D., Brown, J.G., Haxel, G.B., Hayes, T.S., Jensen, E.P., Johnson, D.A., Kamilli, R.J., Long, K.R., Maher, D.J., and Seedorff, E., 2005, Center for Mineral Resources: U.S. Geological Survey-University of Arizona, Department of Geosciences Porphyry Copper Deposit Life Cycles Field Conference, Southeastern Arizona, May 21-22, 2002: U.S. Geological Survey Scientific Investigations Report 2005-5020, 50 p.

Barton, M. D., Seedorff, E., Maher, D. J., Stavast, W. J. A., Kamilli, R. J., Hayes, T., Long, K., Haxel, G. and Cook, S., 2007, Laramide porphyry copper systems and superimposed Tertiary extension: A life cycle approach to the Globe-Superior-Ray area: Guide Book No. 4 for Arizona Geological Association Ores \& Orogenesis Symposium, Tucson, AZ, Arizona Geological Society, $61 \mathrm{p}$.

Barton, M.D., Girardi, J.D., Kreiner, D.C., Seedorff, E., Zurcher, L., Dilles, J.H., Haxel, G.B., and Johnson, D.A., 2011, Jurassic igneous-related metallogeny of southwestern North America, in Steininger, R.C., and Pennell, W.M., eds., Great Basin evolution and metallogeny: Geological Society of Nevada, Symposium, Reno/Sparks, May 2010, Proceedings, v. 1, p. 373-396.

Battles, D.A., and Barton, M.D., 1995, Arc-related sodic hydrothermal alteration in the western United States: Geology, v. 23, p. 913-916.

Baumgartner, M., and Bakker, R.J., 2009, $\mathrm{CaCl}_{2}$-hydrate nucleation in synthetic fluid inclusions: Chemical Geology, v. 265, p. 335-344.

Beus, S.S., 1989, Devonian and Mississippian geology of Arizona: Arizona Geological Society Digest 17, p. 485-514.

Blakey, R.C., and Knepp, R., 1989, Pennsylvanian and Permian geology of Arizona: Arizona Geological Society Digest 17, p. 485-514.

Bodnar, R. J., Lecumberri-Sanchez, P., Moncada, D., Steele-MacInnis, M., 2014. Fluid inclusions in hydrothermal ore deposits, in Scott, S.D., eds., Treatise on Geochemistry, Second Edition, v. 13: Elsevier, Oxford, p. 119-142.

Bowman, J.R., Parry, W.T., Kropp, W.P., and Kruer, S.A., 1987, Chemical and isotopic evolution of hydrothermal solutions at Bingham, Utah: Economic Geology, v. 82, no. 2, p. 
395-428.

Bradfish, L.J., 1979, Petrogenesis of the Tea Cup granodiorite, Pinal County, Arizona: Unpublished M. S. thesis, Tucson, University of Arizona, 160 p.

Bright, R.M., Amato, J.M., Denyszyn, S.W., and Ernst, R.E., 2014, U-Pb geochronology of 1.1 Ga diabase in the southwestern United States: Testing models for the origin of a postGrenville large igneous province: Lithosphere, v. 6; no. 3, p. 135-156.

Brimhall, G.H, Dilles, J.H., and Proffett, J.M., Jr., 2006, The role of geologic mapping in mineral exploration, in Doggett, M.D., and Parry, J.R., eds., Wealth creation in the minerals industry: Integrating, science, business, and education: Society of Economic Geologists Special Publication 12, p. 221-241.

Burnham, C.W., 1979, Magmas and hydrothermal fluids, in Barnes, H.L., ed., Geochemistry of hydrothermal ore deposits, 2nd Edition: New York, John Wiley and Sons, p. 71-136.

Butler, B.S., Wilson, E.D., and Rasor, C.A., 1938, Geology and ore deposits of the Tombstone district, Arizona: Arizona Bureau of Mines Geological Series no. 10, Bulletin 143, 114 p.

Butler, W. C., 1971, Permian sedimentary environments in southeastern Arizona: Arizona Geological Society Digest 9, p. 71-93.

Carten, R.B., 1986, Sodium-calcium metasomatism: Chemical, temporal, and spatial relationships at the Yerington, Nevada, porphyry copper deposit: Economic Geology, v. 81, p. 1495-1519.

Cathles, L.M., 1977, An analysis of the cooling of intrusives by ground-water convection which includes boiling: Economic Geology, v. 72, p. 804-826.

Cathles, L.M., 1990, Scales and effects of fluid flow in the upper crust: Science, v. 248, p. 323329.

Chacko, T., Riciputi, R., Cole, R.D., and Horita, J., 1999, A new technique for determining equilibrium hydrogen isotope fractionation factors using the ion microprobe: Application to the epidote-water system: Geochimica et Cosmochimica Acta, v. 63, p. 1-10.

Chen, H., Clark, A.H., and Kyser, T.K., 2010, The Marcona magnetite deposit, Ica, south-central Peru: A product of hydrous, iron oxide-rich melts?: Economic Geology, v. 105, p. 1441-1456. Coney, P.J., and Reynolds, S.J., 1977, Cordilleran Benioff zones: Nature, v. 270, p. 403-406. Cooper, J.R., 1960, Some geologic features of the Pima mining district, Pima County, Arizona: U.S. Geological Survey Bulletin 1112-C, scale 1:31,680, 103 p.

Corn, R.M., and Ahern, R., 1994, Structural rotation and structural cover at the Kelvin porphyry copper prospect, Pinal County, Arizona, in Miller, M., ed., A geologic tour of the Ray copper deposit and the Kelvin copper prospect, Pinal County, AZ: Arizona Geological Society Spring 1994 Field Trip Guidebook, 16 April 1994, p. 31-42.

Cox, D.P., and Ohta, E., 1984, Maps showing rock types, hydrothermal alteration, and distribution of fluid inclusions in the Cornelia pluton, Ajo mining district, Pima County, Arizona: U.S. Geological Survey Open-File Report 84-388, map scale 1:24,000, 8 p.

Cox, D.P., Force, E.R., Wilkinson, W.H., More, S.W., Rivera, H.S., and Wooden, J.L., 2006, The Ajo mining district, Pima County, Arizona-Evidence for middle Cenozoic detachment faulting, plutonism, volcanism, and hydrothermal alteration: U.S. Geological Survey Professional Paper 1733, map scale 1:24,000, 46 p.

Davis, G.H., and Hardy, J.J., 1981, The Eagle Pass detachment, southeastern Arizona: Product of mid-Miocene listric(?) normal faulting in the southern Basin and Range: Geological Society of America Bulletin, Part I, v. 92, p. 749-762.

Dettman, D., 1994, Stable isotope studies of fresh-water bivalves (Unionidae) and Ostracodes 
(Podocopida): Implications for Late Cretaceous / Paleogene and Early Holocene paleoclimatology and paleohydrology of North America: Unpublished Ph.D. thesis, Ann Arbor, University of Michigan, $215 \mathrm{p}$.

Dickinson, W.R., 1989, Tectonic setting of Arizona through geologic time: Arizona Geological Society Digest 17, p. 1-16.

Dickinson, W.R., 1991, Tectonic setting of faulted Mid-Cenozoic strata associated with the Catalina core complex in southern Arizona: Geological Society of America Special Paper 264, $106 \mathrm{p}$.

Dickinson, W.R., 2002, The Basin and Range province as a composite extensional domain: International Geology Review, v. 44, p. 1-38.

Dickinson, W.R., 2004, Evolution of the North American Cordillera: Annual Review of Earth and Planetary Sciences, v. 32, p. 13-45.

Dilles, J.H., and Einaudi, M.T., 1992, Wall-rock alteration and hydrothermal flow paths about the Ann-Mason porphyry copper deposit, Nevada - A 6-km vertical reconstruction: Economic Geology, v. 87, p. 1963-2001.

Dilles, J.H., Solomon, G.C., Taylor, H.P., Jr., and Einaudi, M.T., 1992, Oxygen and hydrogen isotope characteristics of hydrothermal alteration at the Ann-Mason porphyry copper deposit, Yerington, Nevada: Economic Geology, v. 87, p. 44-63.

Dilles, J. H., Farmer, G. L., and Field, C. W., 1995, Sodium-calcium alteration by non-magmatic saline fluids in porphyry copper deposits: Results from Yerington, Nevada, in Thompson, J. F. H., ed., Magmas, fluids, and ore deposits: Mineralogical Association of Canada Short Course, v. 23, p. 309-338.

Dilles, J.H., Einaudi, M.T., Proffett, J.M., Jr., and Barton, M.D., 2000, Overview of the Yerington porphyry copper district: Magmatic to nonmagmatic sources of hydrothermal fluids, their flow paths, alteration effects on rocks, and $\mathrm{Cu}-\mathrm{Mo}-\mathrm{Fe}-\mathrm{Au}$ ores: Society of Economic Geologists Guidebook Series, v. 32, p. 55-66.

Djouka-Fonkwé, M.L., Kyser, K., Clark, A.H., Urqueta, E., Oates, C.J., Ihlenfeld, C., 2012, Recognizing propylitic alteration associated with porphyry $\mathrm{Cu}-\mathrm{Mo}$ deposits in lower greenschist facies metamorphic terrain of the Collahuasi District, Northern Chile implications of petrographic and carbon isotope relationships: Economic Geology, v. 107, p. 1457-1478.

Drewes, H.D., 1971, Geologic map of the Sahuarita quadrangle, southeast of Tucson, Pima County, Arizona: U.S. Geological Survey Miscellaneous Geologic Investigations Map I-163, scale $1: 48,000$.

Duke, J.C., 2001, Supergene copper enrichment at Hanover Mountain, New Mexico: Unpublished Ph.D. thesis, Tucson, University of Arizona, $128 \mathrm{p}$.

Eberly, L.D., and Stanley, T.B., Jr., 1978, Cenozoic stratigraphy and geologic history of southwestern Arizona: Geological Society of America Bulletin, v. 89, p. 921-940.

Einaudi, M.T., 1982, Description of skarns associated with porphyry copper plutons, in Titley, S.R., ed., Advances in geology of the porphyry copper deposits, southwestern North America: Tucson, University of Arizona Press, p. 139-183.

Ferguson, C.A., Johnson, B.J., Pearthtree, P.A., Spencer, J.E., Shipman, T.C., and Cook, J.P, 2009, Geologic map of the Helvetia 7 1/2' quadrangle, Pima County, Arizona: Arizona Geological Survey Open-File Report 09-06, scale 1:24,000.

Fournier, R.O., 1999, Hydrothermal processes related to movement of fluid from plastic into brittle rock in the magmatic-epithermal environment: Economic Geology, v. 94, p. 1193- 
1211.

Gehrels, G.E., Valencia, V., and Ruiz, J., 2008, Enhanced precision, accuracy, efficiency, and spatial resolution of U-Pb ages by laser ablation-multicollector-inductively coupled plasmamass spectrometry: Geochemistry, Geophysics, Geosystems, v.9, doi:10.1029/2007GC001805.

Giggenbach, W.F., 1997, The origin and evolution of fluids in magmatic-hydrothermal systems, in Barnes, H.L., eds., Geochemistry of hydrothermal ore deposits, $3^{\text {rd }}$ ed.: New York, John Wiley and Sons, p. 737-796.

Gilluly, J., 1942, The mineralization of the Ajo copper district, Arizona: Economic Geology, v. 37, p. 247-309.

Gilluly, J., 1945, Emplacement of the Uncle Sam Porphyry, Tombstone district, Arizona: American Journal of Science, v. 243, p. 643-666.

Gilluly, J., 1946, The Ajo mining district, Arizona: U. S. Geological Survey Professional Paper 209, 112 p.

Goldstein, R.H., and Reynolds, T.J., 1994, Systematics of fluid inclusions in diagenetic minerals: SEPM (Society for Sedimentary Geology) Short Course 31, 199 p.

Grant, J.A., 1986, The isocon diagram: A simple solution to Gresen's equation for metasomatic alteration: Economic Geology, v. 112, p. 1976-1982.

Graybeal, F.T., 1982, Geology of the El Tiro area: Silver Bell mining district, Pima County, Arizona, in Titley, S.R., ed., Advances in geology of the porphyry copper deposits, southwestern North America: Tucson, University of Arizona Press, p. 487-507.

Gregory, M.J., 2017, A fluid inclusion and stable isotope study of the Pebble porphyry coppergold-molybdenum deposit, Alaska: Ore Geology Reviews, v. 80, p. 1279-1303.

Guillong, M., Meier, D.L., Allan, M.M., Heinrich, C.A., and Yardley, B.W.D., 2008, Appendix A6: SILLS: A MATLAB-based program for the reduction of laser ablation ICP-MS data of homogeneous materials and inclusions, in Sylvester, P.J., ed., Laser ablation ICP-MS in the earth sciences: Current practices and outstanding issues: Mineralogical Association of Canada Short Course, v. 40, p. 328-333.

Gustafson, L.B., 1978, Some major factors of porphyry copper genesis: Economic Geology, v 73, p. 600-607.

Gustafson, L.B., and Hunt, J.P., 1975, The porphyry copper deposit at El Salvador, Chile: Economic Geology, v. 70, p. 857-912.

Hagstrum, J.T., Cox, D.P., and Miller, R.J., 1987, Structural reinterpretation of the Ajo mining district, Pima County, Arizona, based on paleomagnetic and geochronologic studies: Economic Geology, v. 82, p. 1348-1361.

Hanson, R.B., 1996, Hydrodynamics of magmatic and meteoric fluids in the vicinity of granitic intrusions: Transactions of the Royal Society of Edinburgh, Earth Sciences, v. 87, p. 251-259.

Hanson, R.B., Sorensen, S.S., Barton, M.D., and Fiske, R.S., 1993, Long-term evolution of fluidrock interactions in magmatic arcs: Evidence from the Ritter Range pendant, Sierra Nevada, California, and numerical modeling: Journal of Petrology, v. 34, p. 23-62.

Hayes, P.T., 1970, Cretaceous Paleogeography of southeastern Arizona and adjacent areas: U.S. Geological Survey Professional Paper 658-B, 45 p.

Haynes, F.M., and Titley, S.R., 1980, The evolution of fracture-related permeability within the Ruby Star granodiorite, Sierrita porphyry copper deposit, Pima County, Arizona: Economic Geology, v. 75, p. 673-683.

Hedenquist, J.W., and Lowenstern, J.B., 1994, The role of magmas in the formation of 
hydrothermal ore deposits: Nature, v. 370, p. 519-527.

Heinrich, C.A., 1990, The chemistry of hydrothermal tin(-tungsten) ore deposition: Economic Geology, v. 85, p. 457-481.

Hemley, J.J., and Jones, W.R., 1964, Chemical aspects of hydrothermal alteration with emphasis on hydrogen metasomatism: Economic Geology, v. 59, p. 538-569.

Hernon, R.M., and Jones, W.R., 1968, Ore deposits of the Central mining district, Grant County, New Mexico, in Ridge, J.D., ed., Ore deposits of the United States, 1933-1967 (Graton-Sales Volume): New York, American Institute of Mining Metallurgy Petroleum Engineers, v. 2, p. 1211-1237.

Herrmann, M.A., 2001, Episodic magmatism and hydrothermal activity, Pima mining district, Arizona: Unpublished M. S. thesis, Tucson, University of Arizona, 44 p.

Hillesland, L.L., Hawkins, R.B., and Worthington, W.T., 1995, The geology and mineralization of the Continental mine area, Grant County, New Mexico: Arizona Geological Society Digest 20, p. 473-483.

Holland, T.J.B., and Blundy, J.D., 1994, Non-ideal interactions in calcic amphiboles and their bearing on amphibole-plagioclase thermometry: Contributions to Mineralogy and Petrology, v. 116, p. $433-447$.

Huyck, H.L.O., 1990, The Lakeshore porphyry copper deposit, Pinal County, Arizona: Geologic setting and physical controls of mineralization: Economic Geology, v. 83, p. 77-86.

Jansen, L.J., 1982, Stratigraphy and structure of the Mission copper deposit, Pima mining district, Pima County, Arizona, in Titley, S.R., ed., Advances in geology of the porphyry copper deposits, southwestern North America: Tucson, University of Arizona Press, p. 467474.

Jones, W.R., Hernon, R.M., and Moore, S.L., 1967, General geology of Santa Rita quadrangle, Grant County, New Mexico: U.S. Geological Survey Professional Paper 555, 144 p.

King, C.A., 2017, Igneous petrology, geochronology, alteration, and mineralization associated with Eocene hydrothermal systems in the Battle Mountain district, Nevada: Unpublished Ph.D. thesis, Tucson, University of Arizona, 707 p.

Koski, R.A., and Cook, D.S., 1982, Geology of the Christmas porphyry copper deposit, Gila County, Arizona, in Titley, S.R., ed., Advances in geology of the porphyry copper deposits, southwestern North America: Tucson, University of Arizona Press, p. 353-374.

Kouzmanov, K., and Pokrovski, G.S., 2016, Hydrothermal controls on metal distribution in porphyry $\mathrm{Cu}(-\mathrm{Mo}-\mathrm{Au})$ systems: Society of Economic Geologists Special Publication 16, p. 573-618.

Kreiner, D.C., and Barton, M.D., 2017, Sulfur-poor intense acid hydrothermal alteration: A distinctive hydrothermal environment: Ore Geology Reviews, v. 88, p. 174-187.

Lasky, S.G., 1936, Geology and ore deposits of the Bayard area, Central mining district, New Mexico: U.S. Geological Survey Bulletin 870, 144 p.

Leveille, R.A., and Stegen, R.J., 2012, The southwestern North America porphyry copper province: Society of Economic Geologists Special Publication 16, p. 361-401.

Liou, J.G., Seki, Y., Guillemette, R.N., and Sakai, H., 1985, Compositions and parageneses of secondary minerals in the Onikobe geothermal system, Japan: Chemical Geology, v. 49, p. 120.

Lopez, J.A., and Titley, S.R., 1995, Outcrop and capping characteristics of the supergene sulfide enrichment at North Silver Bell, Pima County, Arizona: Arizona Geological Digest 20, p. 424-435. 
Lowell, J.D., 1968, Geology of the Kalamazoo orebody, San Manuel district, Arizona: Economic Geology, v. 63, p. 645-654.

Maher, D.J., 2008, Reconstruction of middle Mid-Cenozoic extension and Laramide porphyry copper systems, east-central Arizona: Unpublished Ph. D. thesis, University of Arizona, 328 p.

Meijer, A., 2014, The Pinal Schist of southern Arizona: A Paleoproterozoic forearc complex with evidence of spreading ridge-trench interaction at ca. $1.65 \mathrm{Ga}$ and a Proterozoic arc obduction event: Geological Society of America Bulletin, v. 126, no. 9/10, p. 1145-1163.

Meyer, C., and Hemley, J.J., 1967, Wall rock alteration, in Barnes, H.L., ed., Geochemistry of hydrothermal ore deposits: New York, Holt, Rinehart, and Winston, p. 166-235.

Mizer, J.D., 2018, Early Laramide magmatism in southern Arizona; U-Pb geochronology of key igneous units and implications for the timing of regional porphyry copper mineralization: Unpublished Ph.D. thesis, Tucson, University of Arizona, 619 p.

Mizer, J.D., Barton, M D., and Stegen, R.J., 2015, U-Pb geochronology of Laramide magmatism related to $\mathrm{Cu}-, \mathrm{Zn}$-, and Fe- mineralized systems, Central mining district, New Mexico, in Pennell, W.M., and Garside, L.J., eds., New concepts and discoveries, Geological Society of Nevada, Symposium, Reno/Sparks, May 2015, Proceedings, v. 2, p. 1109-1129.

Moore, R.B., 1993, Geologic map of the Tombstone volcanic center, Cochise County, Arizona: U.S. Geological Survey Miscellaneous Investigations Series Map I-2420, scale 1:50,000.

Muntean, J.L., Einaudi, M.T., 2000, Porphyry gold deposits of the Refugio District, Maricunga Belt, Northern Chile: Economic Geology, v. 95, p. 1445-1472.

Nickerson, P.A., 2012, Post-mineral normal faulting in Arizona porphyry systems: Unpublished $\mathrm{Ph} . \mathrm{D}$. thesis, Tucson, University of Arizona, $310 \mathrm{p}$.

Nickerson, P.A., and Seedorff, E., 2016, Dismembered porphyry systems near Wickenburg, Arizona: District-scale reconstruction with an arc-scale context: Economic Geology, v. 111, no. 2, p. 447-466.

Nickerson, P. A., Barton, M. D., and Seedorff, E., 2010, Characterization and reconstruction of multiple copper-bearing hydrothermal systems in the Tea Cup porphyry system, Pinal County, Arizona: Society of Economic Geologists Special Publication 15, p. 299-316.

Norman, D.K., Parry, W.T., and Bowman, J.R., 1991, Petrology and geochemistry of propylitic alteration at Southwest Tintic, Utah: Economic Geology, v. 86, p. 13-28.

Oreskes, N., and Einaudi, M.T., 1992, Origin of hydrothermal fluids at Olympic Dam: Preliminary results from fluid inclusions and stable isotopes: Economic Geology, v. 87, p. 6490.

Orovan, E.A., Cooke, D.R., Harris, A.C., Ackerman, B., and Lawlis, E., 2018, Geology and isotope geochemistry of the Wainaulo Cu-Au porphyry deposit, Namosi District, Fiji: Economic Geology, v. 113, p. 133-161.

Osatenko, M.J., and Jones, M.B., 1976, Valley Copper: Canadian Institute of Mining and Metallurgy Special Volume 15, p. 130-143.

Parry, W.T., Jasumback, M., and Wilson, P.N., 2002, Clay mineralogy of phyllic and intermediate argillic alteration at Bingham, Utah: Economic Geology, v. 97, p. 221-239.

Pearce, N.J.G., Perkins, W.T., Westgate, J.A., Gorton, M.P., Jackson, S.E., Neal, C.R., and Chemery, S.P., 1997, A compilation of new and published major and trace element data for NIST SRM 610 and NIST SRM 612 glass reference materials: Geostandards NewsletterJournal of Geostandards and Geoanalysis, v. 21, no. 1, p. 115-144.

Pearthree, P.A., Ferguson, C.A., and Demsey, K.A., 2006, Geologic map of the Lewis Springs 7 
1/2' quadrangle, Cochise County, Arizona: Arizona Geological Survey Digital Geologic Map 51 (DGM-51), scale 1:24,000, text 11 p.

Peirce, H.W., 1976, Tectonic significance of Basin and Range thick evaporite deposits: Arizona Geological Society Digest 10, p. 325-339.

Peirce, H.W., and Gerrard, T.A., 1966, Evaporite deposits of the Permian Holbrook basin, Arizona, in Second symposium on salt, v. 1, Geology, geochemistry, mining: Cleveland, Ohio, Northern Ohio Geological Society, p. 1-10.

Pirajno, F., 2009, Hydrothermal processes associated with meteorite impacts: Hydrothermal processes and mineral systems, Belin, Springer, $1250 \mathrm{p}$.

Preece, R.K., III, and Beane, R.E., 1982, Contrasting evolutions of hydrothermal alteration in quartz monzonite and quartz diorite wall rocks at the Sierrita porphyry copper deposit,

Arizona: Economic Geology, v. 77, p. 1621-1641.

Ransome, F.L., 1919, The copper deposits of Ray and Miami, Arizona: U.S. Geological Survey Professional Paper 115, 192 p.

Rauzi, S.L., 2000, Permian salt in the Holbrook Basin, Arizona: Arizona Geological Survey Open-File Report 00-03, 20 p.

Reed, M.H., 1997, Hydrothermal alteration and its relationship to ore fluid composition, in Barnes, H.L., ed., Geochemistry of hydrothermal ore deposits, 3rd Edition: New York, John Wiley and Sons, p. 303-365.

Reyes, A., 1990, Petrology of Philippine geothermal systems and the application of alteration mineralogy to their assessment: Journal of Volcanology and Geothermal Research, v. 43, p. 279-309.

Richard, K., and Courtright, J.H., 1966, Structure and mineralization at Silver Bell, Arizona, in Titley, S.R., and Hicks, C.L., eds., Geology of the porphyry copper deposits, southwestern North America: Tucson, University of Arizona Press, p. 157-163.

Rose, A.W., and Burt, D.M., 1979, Hydrothermal alteration, in Barnes, H.L., ed., Geochemistry of hydrothermal ore deposits, 2nd Edition: New York, John Wiley and Sons, p. 173-235.

Runyon, S.E., 2017, Deep hydrothermal alteration in porphyry copper systems: Insights from the Laramide arc: Unpublished Ph.D. thesis, Tucson, University of Arizona, 624 p.

Runyon, S.E., Barton, M.D., Dilles, J.H., Ohlin, H.N., Seedorff, E., Carpenter, K., and Johnson, D.A., 2015, Iron oxide-rich mineralization and related alteration in the Yerington district, Lyon County, Nevada, in Pennell, W.M., and Garside, L.J., eds., New concepts and discoveries: Geological Society of Nevada, Symposium, Reno/Sparks, May 2015, Proceedings, v. 1, p. 251-283.

Schmidt, E.A., 1971, A structural investigation of the northern Tortilla Mountains, Pinal County, Arizona: Unpublished Ph.D. thesis, University of Arizona, Tucson, 248 p.

Seedorff, E., 1991, Royston district, Western Nevada - A Mesozoic porphyry copper system that was tilted and dismembered by Tertiary normal faults: in Raines, G.L., Lisle, R.E., Schafer, R.W., and Wilkinson, W.H., eds., Geology and Ore Deposits of the Great Basin: Geological Society of Nevada, Symposium, Reno/Sparks, April 1990, Proceedings, v. 1, p. 359-392.

Seedorff, E., Dilles, J.H., Proffett, J.M., Jr., Einaudi, M.T., Zurcher, L., Stavast, W.J.A., Johnson, D.A., and Barton, M.D., 2005a, Porphyry deposits: Characteristics and origin of hypogene features, in Hedenquist, J.W., Thompson, J.F.H., Goldfarb, R.J., and Richards, J.P., eds., Economic Geology 100th Anniversary Volume, p. 251-298.

Seedorff, E., Barton, M.D., Gehrels, G.E., Johnson, D.A., Maher, D.J., Stavast, W.J.A., and Flesch, E., 2005b, Implications of new U-Pb dates from porphyry copper-related plutons in 

Abstracts with Programs, v. 37, no. 7, p. 164.

Seedorff, E., Barton, M.D., Stavast, W.J.A., and Maher, D.J., 2008, Root zones of porphyry systems: Extending the porphyry model to depth: Economic Geology, v. 103, p. 939-956.

Seki, Y., 1972, Lower-grade stability limit of epidote in the light of natural occurrences: Journal of the Geological Society of Japan, v. 78, p. 405-413.

Sheppard, S.M.F., 1986, Characterization and isotopic variations in natural waters: Reviews in Mineralogy and Geochemistry, v. 16, p. 65-184.

Sheppard, S.M.F., and Gustafson, L.B., 1976, Oxygen and hydrogen isotopes in the porphyry copper deposit at El Salvador, Chile: Economic Geology, v. 71, n. 8, p. 1549-1559.

Sheppard, S.M.F., Nielsen, R.L., and Taylor, H.P., Jr., 1971, Hydrogen and oxygen isotope ratios in minerals from porphyry copper deposits: Economic Geology, v. 66, p. 515-542.

Shride, A.F., 1967, Younger Precambrian geology in southern Arizona: U.S. Geological Survey Professional Paper 566, $89 \mathrm{p}$.

Sillitoe, R.H., 2010, Porphyry copper systems: Economic Geology, v. 105, p. 3-41.

Skotnicki, S.J., 1999, Geologic map of the Ninetysix Hills, Pinal County, Arizona: Arizona Geological Survey Open-File Report 99-20, map scale 1:24,000, 14 p.

Spencer, J.E., Isachsen, C.E., Ferguson, C.A., Richard, S.M., Skotnicki, S.J., Wooden, J.L., and Riggs, N.R., 2003, U-Pb isotope geochronologic data from 23 igneous rock units in central and southeastern Arizona: Arizona Geological Survey Open-File Report 03-08, 40 p.

Stavast, W.J.A., 2006, Three-dimensional evolution of magmatic hydrothermal systems, Schultze granite and Ruby Star granodiorite, Arizona: Unpublished Ph.D. thesis, Tucson, University of Arizona, $414 \mathrm{p}$.

Stavast, W.J.A., Barton, M.D., and Seedorff, E., 2007, Roots of a pluton and porphyry copper system, Pima district, Arizona: Ores and orogenesis: Circum-Pacific tectonics, geologic evolution, and ore deposits: Arizona Geological Society, Symposium, Tucson, September 2007, Field Trip 7 Guidebook, 15 p.

Stavast, W.J.A., Butler, R.F., Seedorff, E., Barton, M.D., and Ferguson, C.A., 2008, MidCenozoic tilting and dismemberment of the Laramide arc and related hydrothermal systems, Sierrita Mountains, Arizona: Economic Geology, v. 103, p. 629-636.

Steele-MacInnis, M., Lecumberri-Sanchez, P., Bodnar, R.J., 2012a, HOKIEFlincS_H $\mathrm{H}_{2} \mathrm{O}-$ NACL: A Microsoft Excel spreadsheet for interpreting microthermometric data from fluid inclusions based on the PVTX properties of $\mathrm{H}_{2} \mathrm{O}-\mathrm{NaCl}$ : Computational Geoscience, v. 49, p. 334-337.

Steele-MacInnis, M., Han, L., Lowell, R. P., Rimstidt, J. D., and Bodnar, R. J., 2012b, The role of fluid phase immiscibility in quartz dissolution and precipitation in sub-seafloor hydrothermal systems: Earth and Planetary Science Letters, v. 321-322, p. 139-151.

Suzuoki, T., and Epstein, S., 1976, Hydrogen isotope fractionation between OH-bearing silicate minerals and water: Geochimica et Cosmochimica Acta, v. 40, p. 1229-1240.

Taylor, H.P., Jr., 1974, The application of oxygen and hydrogen isotope studies to problems of hydrothermal alteration and ore deposition: Economic Geology, v. 69, p. 843-883.

Taylor, H.P., Jr., 1979, Oxygen and hydrogen isotope relationships in hydrothermal mineral deposits, in Barnes, H.L., ed., Geochemistry of hydrothermal ore deposits, 2nd Edition: New York, John Wiley and Sons, p. 236-277.

Thoman, M.W., North, R.M., and Worthington, W.T., 2006, Santa Rita porphyry copper deposit, Grant County, New Mexico: A summary, in Stegen, R.J., ed., Tyrone and Santa Rita porphyry 

4-5 November 2006, p. 30-84.

Titley, S.R., ed., 1982, Advances in geology of the porphyry copper deposits, southwestern North America: Tucson, University of Arizona Press, 560 p.

Titley, S.R., and Anthony, E.Y., 1989, Laramide mineral deposits in Arizona: Arizona Geological Society Digest 17, p. 485-514.

Torresi, I., Xavier, R.P., Bortholoto, D.F.A., and Monteiro, L.V., 2012, Hydrothermal alteration, fluid inclusions and stable isotope systematics of the Alvo 118 iron oxide-copper-gold deposit, Carajás Mineral Province (Brazil): Implications for ore genesis: Mineralium Deposita, v. 47, no. 3, p. 299-323.

West, R.J., and Aiken, D.M., 1982, Geology of the Sierrita-Esperanza deposit: Pima mining district, Pima County, Arizona, in Titley, S.R., ed., Advances in geology of the porphyry copper deposits, southwestern North America: Tucson, University of Arizona Press, p. 433465.

Wilkinson, W.H., Jr., More, S.W., and Rivera, J.S., 2010, The New Cornelia deposit, Ajo, Arizona: New insights from recent investigations, in Shakel, D.W., ed., A field visit to the New Cornelia open-pit copper mine, Ajo, Arizona: Arizona Geological Society Field Trip Guidebook, Fall 2010, 16 October 2010, 17 p.

Williams, P.J., Barton, M.D., Johnson, D.A., Fontboté, L., de Haller, A., Mark, G., Oliver, N.H.S., and Marschik, R., 2005, Iron oxide copper-gold deposits: Geology, space-time distribution, and possible modes of origin: Economic Geology $100^{\text {th }}$ Anniversary Volume, $p$. 371-405.

Wilson, E.D., 1962, A resume of the geology of Arizona: Arizona Bureau of Mines Bulletin 171, $77 \mathrm{p}$.

Wrucke, C.T., 1989, The Middle Proterozoic Apache Group, Troy Quartzite, and associated diabase of Arizona: Arizona Geological Society Digest 17, p. 239-258.

Yardley, B.W.D., 2005. Metal concentrations in crustal fluids and their relationship to ore formation. Economic Geology, v. 100, p. 613-632.

Yeend, W., Keith, W.J., and Blacet, P.M., 1977, Reconnaissance geologic map of the Ninetysix Hills NW, NE, SE, and SW quadrangles, Pinal County, Arizona: U.S. Geological Survey Miscellaneous Field Studies Map MP-909, scale 1:62,500.

Zelinski, W.P., 1973, Geologic evaluation of the Kelvin copper-molybdenum prospect, Pinal County, Arizona: Unpublished M.S. thesis, Socorro, New Mexico Institute of Mining and Technology, $72 \mathrm{p}$.

Zurcher, L., 2002, Regional setting and magmatic evolution of Laramide porphyry copper systems in western Mexico: Unpublished Ph.D. thesis, Tucson, University of Arizona, 427 p. 
61079

71080

81081

91082

101083

111084

1085

1086

131087

141088

151089

161090

171091

181092

191093

201094

211095

221096

231097

1098

241099

251100

261101

271102

281103

291104

301105

311106

321107

331108

341109

341110

351111

361112

371113

381114

391115

401116

411117

421118

431119

441120

441121

451122

461123

471124

481125

491126

501127

511128

521129

531130

541131

541132

551133

561134

571135

581136

591137

601138

61

62

63

64

65

Figure 1. Study localities.

Distribution of study localities across Arizona and southwestern New Mexico. Dashed lines represent general extent of Laramide magmatism. Shaded green represents overprint of Basin and Range extension.

Figure 2. Compilation of Na-Ca alteration styles.

A and B) epidote-albite alteration in Cardigan Peak pluton west of New Cornelia mine. C-F) Na-Ca assemblages from KelvinRiverside. C) K-feldspar stable epidote-chlorite-hematite alteration of Ruin granite, and D) plane polarized light microphotograph of andradite-grossular solid solution vein in Ruin granite from Kelvin-Riverside. E) Epidote-albite-chlorite vein in Ruin granite. F) Oligoclase-actinolite-diopside veins and alteration from Silver Bell, showing titanite-diopside replacement of hornblende in back-scattered electron image (G). H and I) Epidote-albite vein from Ninety-Six Hills pre-stain (H) and post-stain (I): yellow stain correlates to potassium-bearing feldspar. J and K) Oligoclase-actinolite-epidote altered Ruby Star granodiorite from north of the Sierrita mine. Pre-stain (L) and post-stain (M) samples of epidote-albite vein from Sycamore Canyon. N) Epidote-chloriteactinolite-albite vein from Sycamore Canyon. Albite-epidote-chlorite in hand sample (O) and pre-stain (P) and post-stain (Q) billets in the quartz diorite of Brunckow Hill, Charleston system. Mineral abbreviations: $a b=$ albite, chl = chlorite, ep $=$ epidote, act $=$ actinolite, $\mathrm{ksp}=\mathrm{K}$-feldspar, grt $=$ garnet, $\mathrm{hm}=$ hematite, olig $=$ oligoclase, $\mathrm{ox} . \mathrm{py}=$ oxidized pyrite, $\mathrm{di}=$ diopside, $\mathrm{ttn}=$ titanite.

Figure 3. Whole-rock analyses.

A) Spider diagrams of whole-rock analyses. Oxide contents are normalized to unaltered host rocks in each district, such that 0 represents no change from host-rock oxide content. Whole-rock data from Sierrita from Stavast (2006). B) Only two whole-rock results are plotted, garnet-stable alteration from Kelvin-Riverside and oligoclase-actinolite alteration from Sierrita, due to the significantly higher REE enrichment in the garnet-stable assemblage. C) Whole-rock trace elements plotted excluding garnetstable Kelvin-Riverside alteration. Oligoclase-actinolite alteration from Sierrita is plotted on both (B) and (C).

Figure 4. Feldspar compositions from Na-Ca styles of alteration.

Feldspar composition data from electron microprobe analyses depicting (A) broad patterns in anorthite content as related to $\mathrm{Sr}$ content and (B) scatter in trace Fe and Sr content. Garnet refers to andradite-grossular solid solution. A) Highest anorthite content is associated with Ca-pyroxene or andradite-bearing assemblages from the Central mining district, whereas near end-member albite is present in albite-chlorite-epidote assemblages from localities such as Ajo, Sycamore Canyon, and Charleston. In panel (B), albite from albite-chlorite-epidote assemblages generally contains less $\mathrm{Sr}$ and $\mathrm{Fe}$ than Na-plagioclase from actinolite-, andradite-grossular solid solution-, or Ca-pyroxene-bearing assemblages.

Figure 5. Amphibole compositions from Na-Ca styles of alteration.

Amphibole compositions from electron microprobe analyses. Garnet refers to andradite-grossular solid solution. A) Mg\# vs. Si apfu. Amphiboles from albite-chlorite-epidote assemblages show a wide range of composition from tremolite replacing original magnesiohornblende at Charleston through tschermakite replacing magnesiohornblende from Sycamore Canyon. Act = actinolite, $\mathrm{Mg}-\mathrm{Hbl}=$ magnesiohornblende, $\mathrm{Ts}=$ tschermakite, Ferro-Act $=$ ferroactinolite, $\mathrm{Fe}-\mathrm{Hbl}=$ ferrohornblende, and $\mathrm{Fe}-\mathrm{Ts}=$ ferrotschermakite. B) Titanium contents show a range of compositions compared to $\mathrm{Na} /(\mathrm{Na}+\mathrm{Ca}+\mathrm{K})$, and the highest $\mathrm{Na} /(\mathrm{Na}+\mathrm{Ca}+\mathrm{K})$ in amphibole is commonly in albite-chlorite-epidote assemblages. C) Lowest observed $\mathrm{Cl}$ content comes from amphibole in albite-chlorite-epidote assemblages, though these also show the widest range in $\mathrm{Cl}$ content and vanadium contents in all analyzed amphiboles is modest.

Figure 6. Epidote compositions

Epidote compositions from electron microprobe analyses. Garnet refers to andradite-grossular solid solution. A) Scatter in the Mn content vs. $\Sigma \mathrm{Fe} /(\Sigma \mathrm{Fe}+\Sigma \mathrm{Al})$ in the hydrothermal epidote, with epidote from Na-plagioclase \pm garnet \pm pyroxene assemblages commonly containing slightly higher $\Sigma \mathrm{Fe} /(\Sigma \mathrm{Fe}+\Sigma \mathrm{Al})$. B) Some scatter in $\mathrm{V}$ content of epidote, with epidote from albite-chloriteepidote assemblages showing the greatest range in $\mathrm{V}$ content and highest $\mathrm{Sr} / \mathrm{Ca} \mathrm{wt} \%$.

Figure 7. Fluid inclusion assemblages from $\mathrm{Na}-\mathrm{Ca}$ alteration minerals from Arizona. A) and (B) Fluid inclusions in epidote from an epidote-chlorite-albite vein from Sycamore Canyon. Images show scattered, secondary or uncertain origin of fluid inclusions. C) High-density, aqueous + vapor fluid inclusions in epidote from albite-epidote-chlorite alteration from the Tea Cup pluton in the Kelvin-Riverside district. D) Dense scattering of secondary or uncertain origin fluid inclusions in garnet from oligoclaseepidote-garnet alteration of the Ruin Granite from the Kelvin-Riverside district. E) and (F) Elongate fluid inclusions in epidote from epidote-albite-chlorite alteration from Ninetysix Hills of secondary or uncertain origin.

Figure 8. A) Phase diagram showing stability fields for feldspars and muscovite at varying aK+/a $\mathrm{a}_{\mathrm{N}}+$ and temperature: illustrates stability fields for albite-dominated, muscovite-stable, and Na-plagioclase-stable Na-Ca alteration assemblages (Dilles et al., 1995). B) Plot showing silica solubility and alkali feldspar exchange: shows stability of albite-stable, quartz-destructive assemblages along warming path of external fluids as opposed to K-feldspar-quartz stable fluids associated with magmatichydrothermal alteration. 
Figure 9. Schematic models of Na-Ca-(K)-(H) development. Box 1: exposures in the Tea Cup composite pluton at KelvinRiverside, with deep and distal garnet-stable $\mathrm{Na}-\mathrm{Ca}$ alteration and deep proximal $\mathrm{Na}-\mathrm{Ca}$ alteration transitional to shallower $\mathrm{Na}$ alteration and shallow $\mathrm{K}-\mathrm{H}^{+}$or $\mathrm{Na}-\mathrm{K}-\mathrm{H}^{+}$alteration to shallowest Fe-oxide rich mineralization. Box 2: exposures at Sycamore Canyon where $\mathrm{Na}-\mathrm{Ca}$ alteration is situated just beneath $\mathrm{Na}$ alteration, both proximal to the Sycamore Canyon stocks. Box 3: exposures at Sierrita, where deep $\mathrm{Na}-\mathrm{Ca}$ alteration transition to $\mathrm{Na}$ and $\mathrm{Ca}-\mathrm{K}$ alteration beneath but proximal to the potassic core 
TABLES

Table 1. Locality descriptions

\begin{tabular}{|c|c|c|c|c|c|c|c|}
\hline $\begin{array}{l}\text { Location } \\
\text { (Host rock) }\end{array}$ & $\begin{array}{l}\text { Age of } \\
\text { intrusion }\end{array}$ & $\begin{aligned} \text { Add } \\
{[\text { replc }}\end{aligned}$ & $\begin{array}{l}\text { ed and Recrystallized Minerals } \\
\text { cing feldspars] \{replacing mafic } \\
\text { minerals }\}^{1,2}\end{array}$ & $\begin{array}{c}\text { Relict } \\
\text { Minerals }^{3}\end{array}$ & $\begin{array}{l}\text { Estimated } \\
\text { Depth } \\
(\mathrm{km})\end{array}$ & Distribution & $\begin{array}{l}\text { Crosscutting } \\
\text { relationships }\end{array}$ \\
\hline \multirow{3}{*}{$\begin{array}{l}\text { Tea Cup, } \\
\text { Arizona }^{4} \\
\text { (Ruin granite) }^{\text {(R) }}\end{array}$} & \multirow{3}{*}{$\begin{array}{l}\sim 72-70 \\
\mathrm{Ma}^{4}\end{array}$} & $\mathrm{Ca}$ & $\begin{array}{c}{[\text { Albite }(\text { An } 00-04)]+\{\text { chlorite }\}+} \\
{[\{\text { epidote }\}] \pm \text { titanite }}\end{array}$ & $\begin{array}{l} \pm \text { Quartz } \pm \\
\text { magnetite } \pm \\
\text { orthoclase }\end{array}$ & $\sim 7-8$ & $\begin{array}{l}\text { Deep, distal } \\
\text { to proximal }\end{array}$ & \multirow{3}{*}{$\begin{array}{l}\text { Postdate and } \\
\text { overprint } \\
\text { potassic } \\
\text { alteration }\end{array}$} \\
\hline & & $\mathrm{Na}-\mathrm{Ca}$ & $\begin{array}{c}\text { [Albite/oligoclase }\left(\mathrm{An}_{01-19)}\right)+ \\
\text { [epidote }]+\{\text { actinolite }\}+\text { titanite } \\
\pm \text { [andradite }]\end{array}$ & \pm Oligoclase & $\sim 6-8$ & Deep, distal & \\
\hline & & $\begin{array}{l}\mathrm{Fe} \\
\text { Oxide }\end{array}$ & $\begin{array}{c}\{\text { Specular hematite }\}+\{\text { chlorite }\} \\
+ \text { quartz } \pm[\text { muscovite }] \pm \\
\text { magnetite } \pm \text { pyrite }\end{array}$ & $\begin{array}{l}\text { Quartz } \pm \\
\text { orthoclase }\end{array}$ & $\sim 2-3$ & $\begin{array}{l}\text { Shallow, } \\
\text { distal }\end{array}$ & \\
\hline $\begin{array}{l}\text { Ninety-Six } \\
\text { Hills, } \\
\text { Arizona }^{5} \text { (Box } \\
\text { O Ranch } \\
\text { granodiorite) }\end{array}$ & $\sim 76 \mathrm{Ma}^{6}$ & $\mathrm{Ca}$ & $\begin{array}{c}\text { [Albite }(\text { An } 00-02)]+[\text { orthoclase }] \\
+[\text { sericite }]+[\text { epidote }]+ \\
\{\text { chlorite }\}+\text { titanite }\end{array}$ & $\begin{array}{l}\text { Quartz } \pm \\
\text { orthoclase }\end{array}$ & $\sim 4-6$ & $\begin{array}{l}\text { Deep, } \\
\text { proximal }\end{array}$ & $\begin{array}{l}\text { Predate } \\
\text { propylitic } \\
\text { alteration }\end{array}$ \\
\hline \multirow{3}{*}{$\begin{array}{l}\text { Central } \\
\text { Mining } \\
\text { District, New } \\
\text { Mexico } \\
\text { (Hanover } \\
\text { Fierro Stock) } \\
\end{array}$} & \multirow{3}{*}{$\sim 58 \mathrm{Ma}^{7}$} & & [Andesine-oligoclase $\left(\mathrm{An}_{23-35)]}\right.$ & & \multirow[b]{3}{*}{$\sim 1-4$} & \multirow{3}{*}{$\begin{array}{l}\text { Shallow to } \\
\text { moderate, } \\
\text { proximal }\end{array}$} & \multirow{3}{*}{$\begin{array}{l}\text { Postdate and } \\
\text { overprint } \\
\text { potassic } \\
\text { alteration }\end{array}$} \\
\hline & & $\mathrm{Na}-\mathrm{Ca}$ & $+\{$ diopside $\}+\{$ actinolite $\}+$ & \pm Quartz & & & \\
\hline & & $\mathrm{Na}$ & $\begin{array}{c}\text { [Albite }(\text { An } 00-07)]+[\text { epidote }]+ \\
\text { titanite }+\{\text { chlorite }\}\end{array}$ & $\begin{array}{c}\text { Quartz } \pm \\
\text { orthoclase }\end{array}$ & & & \\
\hline \multirow{3}{*}{$\begin{array}{l}\text { Eagle Pass, } \\
\text { Arizona }^{4} \\
\text { (Laurel }^{\text {Canyon }} \\
\text { granodiorite) }\end{array}$} & \multirow{3}{*}{$26.5 \mathrm{Ma}^{4}$} & $\begin{array}{l}\mathrm{Na}(\mathrm{qz} \\
\text { stable) }\end{array}$ & $\begin{array}{c}\text { [Albite }]+\{\text { chlorite }\}+[\text { epidote }] \\
+ \text { titanite }\end{array}$ & Orthoclase & $\sim 2-4$ & $\begin{array}{c}\text { Fault } \\
\text { controlled }\end{array}$ & \multirow{3}{*}{$\begin{array}{l}\text { Postdate and } \\
\text { overprint } \\
\text { potassic } \\
\text { alteration }\end{array}$} \\
\hline & & $\mathrm{Na}-\mathrm{Ca}$ & $\begin{array}{c}{[\text { Albite }]+\{\text { chlorite }\}} \\
+\{\text { actinolite }\}+[\text { epidote }] \pm \\
\text { titanite } \pm \text { hematite }\end{array}$ & $\begin{array}{l}\text { Quartz } \pm \\
\text { magnetite }\end{array}$ & $\sim 4$ & $\begin{array}{l}\text { Deep to } \\
\text { shallow, } \\
\text { distal }\end{array}$ & \\
\hline & & $\begin{array}{l}\mathrm{Na}( \pm \\
\mathrm{qz} \\
\text { destru } \\
\text { ctive })\end{array}$ & $\begin{array}{c}\text { [Albite/oligoclase }(\text { Ano1-23) }]+ \\
{[\text { epidote }] \pm\{\text { clinochlore }\} \pm} \\
\{\text { actinolite }\} \pm \text { specular hematite } \\
\pm[\text { muscovite }]\end{array}$ & $\begin{array}{l} \pm \text { Quartz } \pm \\
\text { orthoclase }\end{array}$ & $\sim 5-8$ & Deep, distal & \\
\hline \multirow{3}{*}{$\begin{array}{l}\text { Silver Bell, } \\
\text { Arizona }^{4,9,10} \\
\text { (quartz } \\
\text { monzonite } \\
\text { porphyry) }\end{array}$} & \multirow{3}{*}{$\sim 65 \mathrm{Ma}^{8}$} & $\mathrm{Ca}$ & $\begin{array}{c}{[\text { Plagioclase }]+[\text { garnet }]+} \\
\{\text { hornblende }\}+\{\text { chlorite }\}+ \\
\text { apatite }\end{array}$ & $\begin{array}{l}\text { Quartz } \pm \\
\text { orthoclase }\end{array}$ & $\sim 2-4$ & $\begin{array}{l}\text { Moderate to } \\
\text { deep, } \\
\text { proximal }\end{array}$ & \multirow{3}{*}{$\begin{array}{l}\text { Postdate and } \\
\text { overprint } \\
\text { potassic } \\
\text { alteration }\end{array}$} \\
\hline & & $\mathrm{Na}-\mathrm{Ca}$ & $\begin{array}{c}\{\text { Actinolite }\}+[\text { andesine }(\text { An } 28- \\
\text { 32) }]+\{\text { diopside }\}+\text { titanite }+ \\
\text { apatite }\end{array}$ & Quartz & $\sim 1-3$ & $\begin{array}{l}\text { Shallow to } \\
\text { moderate, }\end{array}$ & \\
\hline & & $\mathrm{Na}$ & $\begin{array}{c}{[\text { Epidote }]+[\text { albite }]+\{\text { chlorite }\}} \\
+[\{\text { sericite }\}] \\
\end{array}$ & \pm Quartz & & proximal & \\
\hline \multirow{3}{*}{$\begin{array}{l}\text { Ajo, } \\
\text { Arizona }^{5,11} \\
\text { (Cardigan } \\
\text { Peak pluton, } \\
\text { New Cornelia } \\
\text { stock) }\end{array}$} & \multirow{3}{*}{$\begin{array}{l}24 \mathrm{Ma}^{11} \\
68-69 \\
\mathrm{Ma}^{12}\end{array}$} & $\mathrm{Na}$ & $\begin{array}{c}\text { Albite }(\text { Ano0-01) }]+\{\text { chlorite }\}+ \\
\text { [epidote] + rutile }\end{array}$ & \pm Quartz & & \multirow{3}{*}{$\begin{array}{c}\text { Fault } \\
\text { controlled }\end{array}$} & \multirow{3}{*}{$\begin{array}{l}\text { Postdate and } \\
\text { overprint all } \\
\text { alteration } \\
\text { associated with } \\
\text { New Cornelia } \\
\text { mine (potassic, } \\
\text { sericitic) }\end{array}$} \\
\hline & & $\mathrm{Na}-\mathrm{Ca}$ & $\begin{array}{c}{[\text { Oligoclase }(\text { An } 75-87)]+} \\
{[\text { epidote }]+\{\text { actinolite }\}+\text { titanite }}\end{array}$ & \pm Quartz & & & \\
\hline & & $\begin{array}{l}\mathrm{Fe} \\
\text { Oxide }\end{array}$ & $\begin{array}{l}\text { Quartz }+ \text { specular hematite }+\mathrm{Cu} \\
\text { oxides }+ \text { chrysocolla }\end{array}$ & $\begin{array}{l} \pm \text { Quartz } \pm \\
\text { orthoclase } \pm \\
\text { magnetite }\end{array}$ & $\sim 1-3$ & & \\
\hline \multirow{3}{*}{$\begin{array}{l}\text { Sierrita, } \\
\text { Arizona }^{13} \\
\text { (Ruby Star } \\
\text { granodiorite) }\end{array}$} & & $\mathrm{Na}$ & $\begin{array}{c}{\left[\text { Albite }\left(\text { An }_{01-03)}\right)+[\{\text { epidote }\}]\right.} \\
+\{\text { chlorite }\}\end{array}$ & Quartz & $\sim 4-8$ & $\begin{array}{l}\text { Deep, } \\
\text { proximal to } \\
\text { distal }\end{array}$ & \multirow{3}{*}{$\begin{array}{l}\text { Postdate and } \\
\text { overprint } \\
\text { potassic } \\
\text { alteration }\end{array}$} \\
\hline & $\begin{array}{l}64-58 \\
\mathrm{Ma}^{13}\end{array}$ & $\mathrm{Na}-\mathrm{Ca}$ & $\begin{array}{c}{\left[\text { Oligoclase }\left(\text { An}_{25-28}\right)\right]+} \\
\{\text { chlorite }\}+\{\text { actinolite }\}+ \\
{[\text { epidote }]+\text { titanite } \pm\{\text { tremolite }\}}\end{array}$ & Quartz & $\sim 4-8$ & $\begin{array}{l}\text { Deep, } \\
\text { proximal to } \\
\text { distal }\end{array}$ & \\
\hline & & $\mathrm{Ca}$ & $\begin{array}{c}\text { [Orthoclase }]+[\{\text { epidote }\}]+ \\
\text { quartz } \pm \text { chalcopyrite }\end{array}$ & $\begin{array}{l}\text { Quartz } \pm \\
\text { orthoclase }\end{array}$ & $\sim 3-5$ & $\begin{array}{l}\text { Deep, } \\
\text { proximal }\end{array}$ & \\
\hline
\end{tabular}




\begin{tabular}{|c|c|c|c|c|c|c|c|}
\hline $\begin{array}{l}\text { Sycamore } \\
\text { Canyon, } \\
\text { Arizona }^{5} \\
\text { (quartz } \\
\text { diorite) } \\
\end{array}$ & $74 \mathrm{Ma}^{5}$ & $\mathrm{Na}-\mathrm{Ca}$ & $\begin{array}{c}{[\text { Orthoclase }]+\left[\text { albite }\left(\text { An }_{00-01}\right)\right]} \\
+[\{\text { epidote }\}]+\{\text { chlorite }\}+ \\
\{\text { tschermakite }\}\end{array}$ & $\begin{array}{l} \pm \text { Quartz } \pm \\
\text { orthoclase }\end{array}$ & $\sim 3-6$ & $\begin{array}{c}\text { Deep, } \\
\text { proximal }\end{array}$ & $\begin{array}{c}\text { Predate coarse } \\
\text { muscovite } \\
\text { alteration, } \\
\text { propylitic } \\
\text { alteration } \\
\end{array}$ \\
\hline $\begin{array}{l}\text { Charleston, } \\
\text { Arizona }^{5} \\
\text { (quartz } \\
\text { diorite, quartz } \\
\text { monzonite) }\end{array}$ & $\sim 76 \mathrm{Ma}^{5}$ & $\mathrm{Na}$ & $\begin{array}{c}{\left[\text { Albite }\left(\text { An }_{00-08}\right)\right]+\{\text { chlorite }\}+} \\
{[\text { epidote }]+\{\text { actinolite }\} \pm} \\
\{\text { tremolite }\}\end{array}$ & $\begin{array}{c}\text { Quartz } \pm \\
\text { orthoclase }\end{array}$ & $\sim 1-3$ & $\begin{array}{l}\text { Shallow, } \\
\text { proximal }\end{array}$ & $\begin{array}{l}\text { Predate } \\
\text { propylitic } \\
\text { alteration }\end{array}$ \\
\hline
\end{tabular}

${ }^{1} \mathrm{An \#}=$ anorthite component in plagioclase

${ }^{2}$ Minerals listed in order of abundance

${ }^{3}$ Minerals occurring in trace amounts not reported

Sources of data: ${ }^{4}$ Nickerson (2012); ${ }^{5}$ This study; ${ }^{6}$ Spencer et al. (2015); ${ }^{7}$ Mizer et al. (2015); ${ }^{8}$ Mizer (2018); ${ }^{9}$ Agenbroad (1962); 10

Graybeal (1982); ${ }^{11}$ Cox et al. (2006); ${ }^{12}$ Runyon (2017), U-Pb zircon age on New Cornelia stock; ${ }^{13}$ Stavast (2006). 
${ }_{5}^{4} 1150$ Table 2. Whole-rock analyses

\begin{tabular}{|c|c|c|c|c|c|c|}
\hline Location & $\begin{array}{l}\text { Kelvin- } \\
\text { Riverside }\end{array}$ & $\begin{array}{c}\text { Kelvin- } \\
\text { Riverside }\end{array}$ & $\begin{array}{c}\text { Kelvin- } \\
\text { Riverside }\end{array}$ & $\begin{array}{c}\text { Sycamore } \\
\text { Canyon }\end{array}$ & $\begin{array}{l}\text { Sycamore } \\
\text { Canyon }\end{array}$ & $\begin{array}{l}\text { Sycamore } \\
\text { Canyon }\end{array}$ \\
\hline Sample & KR-Ca wr & KR Na wr & KR-fr wr & sc-f fr wr & sc-m fr wr & $\begin{array}{l}\text { SC-naca (m- } \\
\text { hosted) wr }\end{array}$ \\
\hline Description $^{1}$ & Grt-olig-ep & Ep-ab-chl & Unalt Ruin & $\begin{array}{c}\text { Unalt qz } \\
\text { monz }\end{array}$ & Unalt qz dio & Ab-ep-chl \\
\hline UTM & $\begin{array}{c}495039 \mathrm{E} \\
3658904 \mathrm{~N}\end{array}$ & $\begin{array}{c}494337 \mathrm{E} \\
3658757 \mathrm{~N}\end{array}$ & $\begin{array}{c}494430 \mathrm{E} \\
3658332 \mathrm{~N}\end{array}$ & $\begin{array}{c}520273 \mathrm{E} \\
3530897 \mathrm{~N}\end{array}$ & $\begin{array}{c}530340 \mathrm{E} \\
3530651 \mathrm{~N}\end{array}$ & $\begin{array}{c}520329 \mathrm{E} \\
3530621 \mathrm{~N}\end{array}$ \\
\hline Wt. (kg) & 0.05 & 0.04 & 0.05 & 0.04 & 0.05 & 0.09 \\
\hline $\mathrm{SiO}_{2}(\%)$ & 59.00 & 67.00 & 70.80 & 70.30 & 50.80 & 50.20 \\
\hline $\mathrm{Al}_{2} \mathrm{O}_{3}(\%)$ & 19.55 & 14.80 & 14.90 & 14.95 & 17.70 & 18.30 \\
\hline $\mathrm{Fe}_{2} \mathrm{O}_{3}(\%)$ & 4.30 & 4.58 & 2.90 & 3.38 & 10.05 & 9.28 \\
\hline $\mathrm{CaO}(\%)$ & 6.52 & 6.62 & 2.32 & 2.89 & 7.29 & 9.84 \\
\hline $\mathrm{MgO}(\%)$ & 0.37 & 0.76 & 1.35 & 0.87 & 4.39 & 3.03 \\
\hline $\mathrm{Na}_{2} \mathrm{O}(\%)$ & 6.34 & 2.95 & 3.32 & 3.19 & 3.04 & 3.45 \\
\hline $\mathrm{K}_{2} \mathrm{O}(\%)$ & 2.25 & 2.04 & 4.48 & 3.75 & 1.98 & 0.73 \\
\hline $\mathrm{Cr}_{2} \mathrm{O}_{3}(\%)$ & $<0.01$ & $<0.01$ & $<0.01$ & $<0.01$ & $<0.01$ & $<0.01$ \\
\hline $\mathrm{TiO}_{2}(\%)$ & 0.58 & 0.30 & 0.31 & 0.35 & 1.16 & 1.08 \\
\hline $\mathrm{MnO}(\%)$ & 0.26 & 0.25 & 0.08 & 0.08 & 0.15 & 0.17 \\
\hline $\mathrm{P}_{2} \mathrm{O}_{5}(\%)$ & 0.25 & 0.11 & 0.11 & 0.11 & 0.33 & 0.34 \\
\hline $\mathrm{SrO}(\%)$ & 0.07 & 0.08 & 0.05 & 0.04 & 0.09 & 0.12 \\
\hline $\mathrm{BaO}(\%)$ & 0.03 & 0.03 & 0.11 & 0.1 & 0.09 & 0.04 \\
\hline LOI & 1.59 & 1.39 & 1.21 & 0.88 & 1.78 & 3.17 \\
\hline Total & 101.11 & 100.91 & 101.94 & 100.89 & 98.85 & 99.75 \\
\hline $\mathrm{C}(\%)$ & 0.1 & 0.07 & 0.05 & 0.05 & 0.09 & 0.16 \\
\hline $\mathrm{S}(\%)$ & 0.03 & 0.03 & 0.03 & 0.02 & 0.03 & 0.02 \\
\hline
\end{tabular}

Trace elements (ppm)

$\begin{array}{lrrrrrr}\mathrm{Ba} & 235 & 278 & 892 & 924 & 831 & 307 \\ \mathrm{Ce} & 86.1 & 23.4 & 17.3 & 50.5 & 45.7 & 49.4 \\ \mathrm{Cr} & 10 & 20 & 20 & 10 & 20 & 30 \\ \mathrm{Cs} & 3.09 & 0.64 & 1.33 & 6.99 & 3.52 & 1.9 \\ \mathrm{Dy} & 11.85 & 1.15 & 1.25 & 2.51 & 4.8 & 4.79 \\ \mathrm{Er} & 8.75 & 0.73 & 0.81 & 1.27 & 2.75 & 2.37 \\ \mathrm{Eu} & 1.64 & 0.65 & 0.51 & 1.04 & 1.77 & 2 \\ \mathrm{Ga} & 19.6 & 29.6 & 16.2 & 17.2 & 25 & 24.9 \\ \mathrm{Gd} & 9.84 & 1.43 & 1.39 & 3.11 & 5.61 & 5.89 \\ \mathrm{Ge} & 7 & 14 & <5 & <5 & <5 & <5 \\ \mathrm{Hf} & 8.9 & 2.6 & 2.3 & 4 & 4.1 & 4.9 \\ \mathrm{Ho} & 2.71 & 0.24 & 0.28 & 0.44 & 0.97 & 0.91 \\ \mathrm{La} & 41.5 & 12.4 & 7.7 & 26.4 & 19.3 & 20.4 \\ \mathrm{Lu} & 1.66 & 0.15 & 0.15 & 0.18 & 0.35 & 0.33 \\ \mathrm{Nb} & 24.2 & 4.4 & 5.1 & 7.5 & 7.5 & 7.9 \\ \mathrm{Nd} & 42.1 & 10.2 & 9.3 & 20.4 & 27 & 30.1 \\ \mathrm{Pr} & 11.1 & 2.88 & 2.28 & 5.79 & 6.59 & 7.16 \\ \mathrm{Rb} & 70.2 & 63.2 & 121 & 116.5 & 56 & 21.5 \\ \mathrm{Sm} & 9.77 & 1.91 & 1.71 & 3.92 & 6.04 & 6.66\end{array}$




\begin{tabular}{|c|c|c|c|c|c|c|}
\hline $\begin{array}{l}\text { Sn } \\
\text { Location }\end{array}$ & $\begin{array}{l}5 \\
\text { Kelvin- } \\
\text { Riverside }\end{array}$ & $\begin{array}{l}{ }_{\text {Kelvin- }}^{1} \\
\text { Riverside }\end{array}$ & $\begin{array}{l}1 \\
\text { Kelvin- } \\
\text { Riverside }\end{array}$ & $\begin{array}{c}\text { Sycamore } \\
\text { Canyon }\end{array}$ & $\underbrace{2}_{\text {Canyonore }}$ & $\begin{array}{c}2 \\
\text { Sycamore } \\
\text { Canyon } \\
\text { SC-naca (m- }\end{array}$ \\
\hline SAMPLE & & & & & sc-m fr wr & hosted) wr \\
\hline $\mathrm{Sr}$ & 547 & 643 & 459 & 386 & 802 & 1075 \\
\hline $\mathrm{Ta}$ & 2.4 & 0.5 & 0.5 & 0.6 & 0.4 & 0.5 \\
\hline $\mathrm{Tb}$ & 1.82 & 0.21 & 0.22 & 0.42 & 0.8 & 0.81 \\
\hline Th & 20.1 & 5.35 & 7.72 & 8.72 & 2.48 & 3.18 \\
\hline $\mathrm{Tm}$ & 1.47 & 0.11 & 0.13 & 0.19 & 0.37 & 0.33 \\
\hline $\mathrm{U}$ & 6.63 & 6.7 & 1.97 & 1.56 & 1.18 & 1.6 \\
\hline V & 33 & 111 & 45 & 41 & 266 & 224 \\
\hline W & 3 & 1 & 1 & 1 & $<1$ & 2 \\
\hline Y & 75.4 & 7.6 & 8 & 13.3 & 25.2 & 24.3 \\
\hline $\mathrm{Yb}$ & 10.6 & 0.81 & 0.92 & 1.29 & 2.55 & 2.19 \\
\hline $\mathrm{Zr}$ & 305 & 84 & 81 & 138 & 169 & 199 \\
\hline As & 1.2 & 0.8 & 0.5 & 1.1 & 0.6 & 1.3 \\
\hline $\mathrm{Bi}$ & 0.61 & 0.15 & 0.02 & 0.28 & 0.05 & 0.14 \\
\hline $\mathrm{Hg}$ & 0.013 & $<0.005$ & $<0.005$ & $<0.005$ & $<0.005$ & $<0.005$ \\
\hline In & 0.218 & 0.079 & 0.008 & 0.014 & 0.027 & 0.012 \\
\hline $\operatorname{Re}$ & $<0.001$ & $<0.001$ & $<0.001$ & $<0.001$ & $<0.001$ & $<0.001$ \\
\hline $\mathrm{Sb}$ & 0.21 & 0.21 & 0.11 & 0.15 & 0.06 & 0.13 \\
\hline $\mathrm{Se}$ & $<0.2$ & $<0.2$ & $<0.2$ & $<0.2$ & $<0.2$ & $<0.2$ \\
\hline $\mathrm{Te}$ & 0.11 & $<0.01$ & 0.01 & 0.04 & 0.01 & 0.24 \\
\hline $\mathrm{Tl}$ & 0.04 & 0.04 & 0.07 & 0.25 & 0.13 & 0.04 \\
\hline $\mathrm{Ag}$ & $<0.5$ & $<0.5$ & $<0.5$ & $<0.5$ & $<0.5$ & $<0.5$ \\
\hline $\mathrm{Cd}$ & 0.8 & 0.7 & $<0.5$ & $<0.5$ & 1.6 & 1.4 \\
\hline Co & 3 & 5 & 7 & 4 & 32 & 27 \\
\hline $\mathrm{Cu}$ & 7 & 4 & 6 & 13 & 80 & 46 \\
\hline $\mathrm{Li}$ & 10 & 10 & 10 & 20 & 30 & 20 \\
\hline Mo & $<1$ & $<1$ & $<1$ & $<1$ & $<1$ & $<1$ \\
\hline $\mathrm{Ni}$ & 3 & 9 & 9 & 2 & 39 & 31 \\
\hline $\mathrm{Pb}$ & 10 & 12 & 10 & 20 & 9 & 16 \\
\hline $\mathrm{Sc}$ & 7 & 4 & 5 & 4 & 15 & 15 \\
\hline $\mathrm{Zn}$ & 29 & 38 & 44 & 50 & 110 & 90 \\
\hline
\end{tabular}

${ }^{1}$ Description. Grt-olig-ep: garnet-bearing oligoclase-epidote dominated alteration. Ep-ab-chl: epidote, albite, and chlorite alteration of host rock. Unalt Ruin: ostensibly unaltered Ruin granite. Unalt qtz monz: ostensibly unaltered quartz monzonite. Unalt qtz dio: ostensibly unaltered quartz diorite. Unalt grano: ostensibly unaltered granodiorite. 
${ }_{5}^{4} 1154$ Table 2. Whole-rock analyses, continued

\begin{tabular}{|c|c|c|c|c|c|c|}
\hline Location & $\begin{array}{l}\text { Ninety-Six } \\
\text { Hills }\end{array}$ & $\begin{array}{l}\text { Ninety-Six } \\
\text { Hills }\end{array}$ & Charleston & Charleston & Charleston & Charleston \\
\hline Sample & $\begin{array}{l}\text { CHE naca } \\
\text { wr }\end{array}$ & CHE fr wr & T16 Nak wr & $\begin{array}{c}\text { T16 wr qtz } \\
\text { monz }\end{array}$ & $\begin{array}{c}\text { T16 qtz dio } \\
\text { wr }\end{array}$ & T16-naca wr \\
\hline Description $^{1}$ & Ab-ep-chl & $\begin{array}{l}\text { Unalt } \\
\text { grano }\end{array}$ & Ab-ep-chl & Unalt qz monz & Unalt qz dio & Ab-ep-chl \\
\hline UTM & $\begin{array}{c}490081 \mathrm{E} \\
3645219 \mathrm{~N}\end{array}$ & $\begin{array}{c}490058 \mathrm{E} \\
3645160 \mathrm{~N}\end{array}$ & $\begin{array}{c}579076 \mathrm{E} \\
3498592 \mathrm{~N}\end{array}$ & $\begin{array}{c}579016 \mathrm{E} \\
3498668 \mathrm{~N}\end{array}$ & $\begin{array}{c}578942 \mathrm{E} \\
3498747 \mathrm{~N}\end{array}$ & $\begin{array}{c}579368 \mathrm{E} \\
3498023 \mathrm{~N}\end{array}$ \\
\hline Wt. $(\mathrm{kg})$ & 0.05 & 0.06 & 0.03 & 0.03 & 0.05 & 0.03 \\
\hline $\mathrm{SiO}_{2}(\%)$ & 66.70 & 69.10 & 65.50 & 61.90 & 60.70 & 61.90 \\
\hline $\mathrm{Al}_{2} \mathrm{O}_{3}(\%)$ & 14.90 & 15.00 & 15.85 & 16.10 & 16.40 & 16.25 \\
\hline $\mathrm{Fe}_{2} \mathrm{O}_{3}(\%)$ & 4.27 & 3.45 & 4.08 & 6.10 & 6.83 & 6.13 \\
\hline $\mathrm{CaO}(\%)$ & 5.38 & 3.26 & 2.52 & 4.50 & 5.07 & 3.99 \\
\hline $\mathrm{MgO}(\%)$ & 0.75 & 1.14 & 1.71 & 2.14 & 2.3 & 2.35 \\
\hline $\mathrm{Na}_{2} \mathrm{O}(\%)$ & 3.65 & 3.35 & 5.16 & 3.35 & 3.5 & 3.64 \\
\hline $\mathrm{K}_{2} \mathrm{O}(\%)$ & 2.58 & 3.69 & 2.46 & 3.12 & 2.93 & 3.34 \\
\hline $\mathrm{Cr}_{2} \mathrm{O}_{3}(\%)$ & $<0.01$ & $<0.01$ & $<0.01$ & $<0.01$ & $<0.01$ & $<0.01$ \\
\hline $\mathrm{TiO}_{2}(\%)$ & 0.42 & 0.38 & 0.60 & 0.74 & 0.86 & 0.77 \\
\hline $\mathrm{MnO}(\%)$ & 0.13 & 0.08 & 0.06 & 0.10 & 0.13 & 0.10 \\
\hline $\mathrm{P}_{2} \mathrm{O}_{5}(\%)$ & 0.15 & 0.13 & 0.17 & 0.21 & 0.25 & 0.23 \\
\hline $\mathrm{SrO}(\%)$ & 0.07 & 0.05 & 0.06 & 0.06 & 0.06 & 0.06 \\
\hline $\mathrm{BaO}(\%)$ & 0.06 & 0.10 & 0.07 & 0.09 & 0.09 & 0.10 \\
\hline LOI & 1.11 & 0.85 & 2.44 & 1.92 & 1.5 & 2.5 \\
\hline Total & 100.17 & 100.58 & 100.68 & 100.33 & 100.62 & 101.36 \\
\hline $\mathrm{C}(\%)$ & 0.04 & 0.06 & 0.06 & 0.06 & 0.04 & 0.08 \\
\hline $\mathrm{S}(\%)$ & 0.02 & 0.03 & 0.02 & 0.02 & 0.02 & 0.02 \\
\hline \multicolumn{7}{|c|}{ Trace elements (ppm) } \\
\hline $\mathrm{Ba}$ & 508 & 869 & 585 & 810 & 780 & 886 \\
\hline $\mathrm{Ce}$ & 50.4 & 55.2 & 69.4 & 66.8 & 59.1 & 70.6 \\
\hline $\mathrm{Cr}$ & 10 & 10 & 10 & 10 & 10 & 20 \\
\hline Cs & 2.25 & 5.71 & 2.08 & 3.79 & 7.54 & 3.38 \\
\hline Dy & 3.33 & 3.35 & 4.53 & 4.31 & 4.37 & 4.71 \\
\hline $\mathrm{Er}$ & 1.91 & 2.09 & 2.73 & 2.42 & 2.42 & 2.75 \\
\hline $\mathrm{Eu}$ & 1.12 & 0.95 & 1.25 & 1.25 & 1.34 & 1.41 \\
\hline $\mathrm{Ga}$ & 23.7 & 19.3 & 16.9 & 19.7 & 19.2 & 20.6 \\
\hline Gd & 3.39 & 3.37 & 4.89 & 4.83 & 4.79 & 5.73 \\
\hline $\mathrm{Ge}$ & $<5$ & $<5$ & $<5$ & $<5$ & $<5$ & $<5$ \\
\hline $\mathrm{Hf}$ & 4.6 & 3.9 & 5 & 5.9 & 5.6 & 6 \\
\hline Ho & 0.66 & 0.7 & 0.91 & 0.82 & 0.84 & 0.94 \\
\hline $\mathrm{La}$ & 27.6 & 29.4 & 35.7 & 33.7 & 29.4 & 34.8 \\
\hline $\mathrm{Lu}$ & 0.3 & 0.36 & 0.41 & 0.38 & 0.34 & 0.4 \\
\hline $\mathrm{Nb}$ & 8 & 10 & 9.7 & 8.9 & 8.6 & 8.9 \\
\hline $\mathrm{Nd}$ & 21.2 & 21.4 & 30.3 & 29 & 27.3 & 31.2 \\
\hline $\operatorname{Pr}$ & 5.99 & 6.22 & 8.32 & 8.03 & 7.38 & 8.63 \\
\hline $\mathrm{Rb}$ & 111.5 & 129 & 117 & 117 & 115.5 & 147 \\
\hline $\mathrm{Sm}$ & 3.99 & 4.18 & 5.82 & 5.82 & 5.6 & 6.45 \\
\hline
\end{tabular}




\begin{tabular}{|c|c|c|c|c|c|c|}
\hline $\mathrm{Sn}$ & & & 2 & 2 & 2 & 2 \\
\hline Location & $\begin{array}{l}\text { Ninety-Six } \\
\text { Hills }\end{array}$ & $\begin{array}{l}\text { Ninety-Six } \\
\text { Hills }\end{array}$ & Charleston & Charleston & Charleston & Charleston \\
\hline SAMPLE & $\begin{array}{c}\text { CHE naca } \\
\text { wr }\end{array}$ & CHE fr wr & T16 Nak wr & $\begin{array}{c}\text { T16 wr qtz } \\
\text { monz }\end{array}$ & $\begin{array}{c}\text { T16 qtz dio } \\
\text { wr }\end{array}$ & T16-naca wr \\
\hline $\mathrm{Sr}$ & 651 & 476 & 534 & 557 & 512 & 571 \\
\hline $\mathrm{Ta}$ & 0.6 & 1.2 & 0.8 & 0.7 & 0.6 & 0.7 \\
\hline $\mathrm{Tb}$ & 0.54 & 0.53 & 0.74 & 0.73 & 0.73 & 0.79 \\
\hline Th & 11.25 & 17.1 & 11.15 & 12.35 & 9.36 & 12.15 \\
\hline $\mathrm{Tm}$ & 0.28 & 0.33 & 0.39 & 0.36 & 0.36 & 0.39 \\
\hline $\mathrm{U}$ & 4.3 & 3.84 & 2.53 & 2.87 & 2.3 & 2.79 \\
\hline V & 74 & 63 & 81 & 104 & 125 & 122 \\
\hline $\mathrm{W}$ & 2 & 4 & 2 & 1 & 2 & 2 \\
\hline Y & 18.7 & 19.9 & 25.2 & 24.1 & 23.5 & 26 \\
\hline $\mathrm{Yb}$ & 1.86 & 2.49 & 2.65 & 2.5 & 2.27 & 2.66 \\
\hline $\mathrm{Zr}$ & 154 & 127 & 194 & 229 & 217 & 226 \\
\hline As & 1.1 & 0.6 & 0.4 & 0.5 & 0.5 & 0.7 \\
\hline $\mathrm{Bi}$ & 1.05 & 0.59 & 0.49 & 0.21 & 0.41 & 0.22 \\
\hline $\mathrm{Hg}$ & $<0.005$ & $<0.005$ & $<0.005$ & $<0.005$ & $<0.005$ & $<0.005$ \\
\hline In & 0.017 & 0.019 & 0.018 & 0.007 & 0.03 & 0.017 \\
\hline $\operatorname{Re}$ & $<0.001$ & $<0.001$ & $<0.001$ & $<0.001$ & $<0.001$ & $<0.001$ \\
\hline $\mathrm{Sb}$ & 0.21 & 0.07 & 0.22 & 0.17 & 0.08 & 0.14 \\
\hline $\mathrm{Se}$ & $<0.2$ & $<0.2$ & $<0.2$ & 0.2 & $<0.2$ & $<0.2$ \\
\hline $\mathrm{Te}$ & 0.09 & 0.01 & 0.03 & 0.01 & 0.01 & 0.01 \\
\hline $\mathrm{Tl}$ & 0.05 & 0.28 & 0.07 & 0.05 & 0.24 & 0.06 \\
\hline $\mathrm{Ag}$ & $<0.5$ & $<0.5$ & $<0.5$ & $<0.5$ & $<0.5$ & $<0.5$ \\
\hline $\mathrm{Cd}$ & $<0.5$ & $<0.5$ & $<0.5$ & $<0.5$ & $<0.5$ & $<0.5$ \\
\hline Co & 4 & 7 & 11 & 14 & 17 & 15 \\
\hline $\mathrm{Cu}$ & 27 & 17 & 29 & 26 & 87 & 29 \\
\hline $\mathrm{Li}$ & 20 & 20 & 10 & 10 & 10 & 10 \\
\hline Mo & 2 & 23 & 2 & 4 & $<1$ & 1 \\
\hline $\mathrm{Ni}$ & 3 & 5 & 6 & 9 & 10 & 10 \\
\hline $\mathrm{Pb}$ & 16 & 17 & 7 & 11 & 14 & 13 \\
\hline $\mathrm{Sc}$ & 6 & 6 & 8 & 9 & 10 & 10 \\
\hline $\mathrm{Zn}$ & 53 & 52 & 65 & 63 & 90 & 75 \\
\hline
\end{tabular}

1 Description. Grt-olig-ep: garnet-bearing oligoclase-epidote dominated alteration. Ep-ab-chl: epidote, albite, and chlorite alteration of host rock. Unalt Ruin: ostensibly unaltered Ruin granite. Unalt qtz monz: ostensibly unaltered quartz monzonite. Unalt qtz dio: ostensibly unaltered quartz diorite. Unalt grano: ostensibly unaltered granodiorite. 
Table 3. Representative hydrothermal feldspar compositions normalized to $4 \sum \mathrm{T}^{1}$

\begin{tabular}{|c|c|c|c|c|c|c|c|c|c|c|}
\hline Locality $^{2}$ & Ajo & Ajo & Sierrita & Sierrita & $\mathrm{SC}$ & CMD & $\begin{array}{c}\text { Eagle } \\
\text { Pass }\end{array}$ & Charleston & KR & $\mathrm{KR}$ \\
\hline Mineral & Olig & $\mathrm{Ab}$ & $\mathrm{Ab}$ & Olig & $\mathrm{Ab}$ & And & $\mathrm{Ab}$ & $\mathrm{Ab}$ & $\mathrm{Ab}$ & Olig \\
\hline Sample & Ajo16-4 & Ajo 16-1 & NS-2c & NS-2e & $\begin{array}{c}\text { SC16- } \\
7\end{array}$ & C38 & SP048 & T16-1a & TC009 & KR-6a \\
\hline UTM & $\begin{array}{c}322984 \\
\mathrm{E} \\
358326 \\
3 \mathrm{~N}\end{array}$ & $\begin{array}{c}322716 \mathrm{E} \\
3582335 \\
\mathrm{~N}\end{array}$ & $\begin{array}{c}491053 \\
\mathrm{E} \\
352951 \\
7 \mathrm{~N}\end{array}$ & $\begin{array}{c}491116 \\
\mathrm{E} \\
352951 \\
8 \mathrm{~N}\end{array}$ & $\begin{array}{c}52032 \\
9 \mathrm{E} \\
35306 \\
21 \mathrm{~N}\end{array}$ & & & $\begin{array}{c}579368 \mathrm{E} \\
3498023 \mathrm{~N}\end{array}$ & $\begin{array}{c}49433 \\
7 \mathrm{E} \\
36587 \\
57 \mathrm{~N}\end{array}$ & $\begin{array}{c}49503 \\
9 \mathrm{E} \\
36589 \\
04 \mathrm{~N}\end{array}$ \\
\hline H.A. ${ }^{3}$ & $\begin{array}{c}\text { Act-Ep- } \\
\text { Ap-Ttn }\end{array}$ & $\begin{array}{c}\text { Ep-Rt- } \\
\text { Chl }\end{array}$ & Ep-Chl & Ep-Act & Ep-Chl & $\begin{array}{c}\text { Px-Ep- } \\
\text { Act }\end{array}$ & Ep-Chl & Ep-Chl & Ep-Chl & Grt-Ep \\
\hline $\begin{array}{l}\mathrm{SiO}_{2} \\
\text { (wt\%) }\end{array}$ & 61.53 & 69.04 & 68.27 & 68.10 & 68.16 & 57.17 & 68.63 & 67.50 & 67.55 & 65.31 \\
\hline $\mathrm{Al}_{2} \mathrm{O}_{3}$ & 24.02 & 20.79 & 19.51 & 20.24 & 20.53 & 26.74 & 19.59 & 21.54 & 20.54 & 22.43 \\
\hline $\mathrm{Fe}_{2} \mathrm{O}_{3}{ }^{4}$ & 0.35 & 0.09 & 0.06 & 0.05 & 0.05 & 0.26 & 0.01 & 0.00 & 0.41 & 0.21 \\
\hline $\mathrm{CaO}$ & 4.95 & 0.41 & 0.11 & 0.47 & 0.16 & 7.94 & 0.02 & 1.26 & 1.15 & 2.59 \\
\hline $\mathrm{SrO}$ & 0.18 & 0.08 & 0.08 & 0.09 & 0.04 & 0.29 & 0.00 & 0.07 & 0.00 & 0.09 \\
\hline $\mathrm{Na}_{2} \mathrm{O}$ & 8.54 & 10.23 & 11.73 & 11.51 & 11.53 & 6.77 & 11.80 & 10.66 & 11.32 & 9.27 \\
\hline $\mathrm{K}_{2} \mathrm{O}$ & 0.23 & 0.05 & 0.09 & 0.08 & 0.26 & 0.50 & 0.03 & 0.09 & 0.03 & 0.14 \\
\hline Total & 99.85 & 100.69 & 99.90 & 100.59 & 100.81 & 99.76 & 100.27 & 101.16 & 101.00 & 100.08 \\
\hline $\begin{array}{l}{ }^{\text {IV }} \mathrm{Si} \\
\text { (apfu) }\end{array}$ & 2.73 & 2.95 & 2.99 & 2.96 & 2.95 & 2.57 & 2.99 & 2.91 & 2.94 & 2.84 \\
\hline${ }^{\mathrm{IV}} \mathrm{Al}$ & 1.26 & 1.05 & 1.01 & 1.04 & 1.05 & 1.42 & 1.01 & 1.09 & 1.05 & 1.15 \\
\hline${ }^{\mathrm{IV}} \mathrm{Fe}^{3+}$ & 0.01 & 0.00 & 0.00 & 0.00 & 0.00 & 0.01 & 0.00 & 0.00 & 0.01 & 0.01 \\
\hline$\sum(\mathrm{IV})$ & 4.00 & 4.00 & 4.00 & 4.00 & 4.00 & 4.00 & 4.00 & 4.00 & 4.00 & 4.00 \\
\hline${ }^{\mathrm{A}} \mathrm{Ca}$ & 0.24 & 0.03 & 0.00 & 0.02 & 0.01 & 0.38 & 0.00 & 0.06 & 0.05 & 0.12 \\
\hline${ }^{\mathrm{A}} \mathrm{Na}$ & 0.74 & 0.94 & 1.00 & 0.97 & 0.97 & 0.59 & 1.00 & 0.89 & 0.95 & 0.78 \\
\hline${ }^{\mathrm{A}} \mathrm{K}$ & 0.01 & 0.00 & 0.00 & 0.00 & 0.01 & 0.02 & 0.00 & 0.01 & 0.00 & 0.01 \\
\hline${ }^{\mathrm{A}} \mathrm{Sr}$ & 0.00 & 0.00 & 0.00 & 0.00 & 0.00 & 0.01 & 0.00 & 0.00 & 0.00 & 0.00 \\
\hline$\sum(\mathrm{A})$ & 0.99 & 0.97 & 1.00 & 1.00 & 0.99 & 1.00 & 1.00 & 0.96 & 1.01 & 0.91 \\
\hline
\end{tabular}

1Elements summed for tetrahedral site for normalization routine: $\mathrm{Ga}, \mathrm{Fe}, \mathrm{Al}, \mathrm{Si}, \mathrm{P}$, and $\mathrm{S}$.

2Locality: Ajo $=$ New Cornelia quartz diorite along the Gibson Arroyo fault. SC $=$ Sycamore Canyon. CMD = Central mining district. $\mathrm{EP}=$ Eagle Pass. $\mathrm{KR}=$ Kelvin-Riverside

3H.A. $=$ hydrothermal assemblage. Act $=$ actinolite; $\mathrm{Ep}=$ epidote; $\mathrm{Ap}=$ apatite; $\mathrm{Ttn}=$ titanite; Rut = rutile; $\mathrm{Chl}=$ chlorite; Ksp = $\mathrm{K}$-feldspar; $\mathrm{Px}=$ pyroxene; $\mathrm{Grt}=$ garnet; $\mathrm{Ab}=$ albite; Olig $=$ oligoclase; And $=$ andesine.

4all $\mathrm{Fe}$ originally measured as $\mathrm{Fe}^{2+} \cdot \mathrm{Fe}_{2} \mathrm{O}_{3}$ and $\mathrm{FeO}$ (and $\mathrm{Fe}^{3+}$ and $\mathrm{Fe}^{2+}$ apfu) calculated by charge balance. 
Table 4. Representative hydrothermal amphibole compositions normalized to 13 Cations

\begin{tabular}{|c|c|c|c|c|c|c|c|c|c|}
\hline Locality $^{1}$ & $\mathrm{SC}$ & SC & Ajo & Charleston & Charleston & KR & $\begin{array}{c}\text { Eagle } \\
\text { Pass }\end{array}$ & CMD & Sierrita \\
\hline Mineral $^{2}$ & Tsch & $\mathrm{Mg}-\mathrm{Hbl}$ & Act & Act & $\operatorname{Tr}$ & Mg-hbl & Act & Act & Act \\
\hline Sample & SC16-7 & SC16-7 & Ajo16-1 & T16-1a & T16-1a & TC 006 & $\begin{array}{l}\text { MW } \\
\text { Alt5, }\end{array}$ & CMD43 & NS-2c \\
\hline UTM & $\begin{array}{c}520329 \mathrm{E} \\
3530621 \mathrm{~N}\end{array}$ & $\begin{array}{c}520329 \mathrm{E} \\
3530621 \mathrm{~N}\end{array}$ & $\begin{array}{c}322716 \mathrm{E} \\
3582335 \mathrm{~N}\end{array}$ & $\begin{array}{c}579368 \mathrm{E} \\
3498023 \mathrm{~N}\end{array}$ & $\begin{array}{c}579368 \mathrm{E} \\
3498023 \mathrm{~N}\end{array}$ & & & & $\begin{array}{c}491053 \mathrm{E} \\
3529517 \mathrm{~N}\end{array}$ \\
\hline H.A. ${ }^{3}$ & Ab-Ep & Ab-Ep & Ab-Ep & Ab-Ep & Ab-Ep & Ab-Ep & Olig-Ep & Olig-Ep & Olig-Ep \\
\hline $\begin{array}{l}\mathrm{SiO}_{2} \\
\text { (wt\%) }\end{array}$ & 41.90 & 45.36 & 54.89 & 54.78 & 53.53 & 51.46 & 55.80 & 51.35 & 55.70 \\
\hline $\mathrm{TiO}_{2}$ & 1.60 & 1.10 & 0.05 & 0.16 & 0.61 & 0.35 & 0.04 & 0.05 & 0.07 \\
\hline $\mathrm{Al}_{2} \mathrm{O}_{3}$ & 11.04 & 8.41 & 2.56 & 1.53 & 2.79 & 4.18 & 1.75 & 2.92 & 1.18 \\
\hline $\mathrm{V}_{2} \mathrm{O}_{3}$ & 0.03 & 0.03 & 0.02 & 0.01 & 0.02 & 0.00 & 0.00 & 0.05 & 0.03 \\
\hline $\mathrm{Mn} 2 \mathrm{O} 3$ & 0.00 & 0.00 & 0.07 & 0.48 & 0.56 & 0.82 & 0.29 & 0.51 & 0.00 \\
\hline $\mathrm{Fe}_{2} \mathrm{O}_{3}{ }^{4}$ & 6.12 & 5.50 & 1.05 & 2.72 & 4.87 & 4.56 & 0.03 & 3.71 & 1.18 \\
\hline $\mathrm{FeO}$ & 13.03 & 11.71 & 5.31 & 6.59 & 3.57 & 7.90 & 9.02 & 10.31 & 5.56 \\
\hline $\mathrm{MnO}$ & 0.43 & 0.48 & 0.06 & 0.43 & 0.51 & 0.73 & 0.26 & 0.45 & 0.18 \\
\hline $\mathrm{MgO}$ & 9.56 & 11.36 & 19.89 & 18.30 & 18.76 & 15.46 & 17.81 & 14.91 & 19.88 \\
\hline $\mathrm{CaO}$ & 11.77 & 11.77 & 13.26 & 12.61 & 11.72 & 12.04 & 12.79 & 12.40 & 13.10 \\
\hline $\mathrm{BaO}$ & 0.02 & 0.02 & 0.00 & 0.32 & 0.82 & 0.53 & 0.00 & 0.00 & 0.00 \\
\hline $\mathrm{Na}_{2} \mathrm{O}$ & 1.19 & 1.03 & 0.38 & 0.11 & 0.32 & 0.29 & 0.31 & 0.49 & 0.14 \\
\hline $\mathrm{K}_{2} \mathrm{O}$ & 1.00 & 0.60 & 0.08 & 0.01 & 0.00 & 0.04 & 0.11 & 0.14 & 0.13 \\
\hline $\mathrm{Cr}_{2} \mathrm{O}_{3}$ & 0.01 & 0.00 & 0.01 & 0.04 & 0.02 & 0.00 & 0.00 & 0.01 & 0.01 \\
\hline $\mathrm{Sc}_{2} \mathrm{O}_{3}$ & 0.02 & 0.02 & 0.01 & 0.00 & 0.00 & 0.00 & 0.00 & 0.01 & 0.01 \\
\hline $\mathrm{NiO}$ & 0.00 & 0.00 & 0.02 & 0.02 & 0.02 & 0.00 & 0.00 & 0.01 & 0.03 \\
\hline $\mathrm{ZnO}$ & 0.02 & 0.02 & 0.00 & 0.01 & 0.01 & 0.00 & 0.00 & 0.02 & 0.01 \\
\hline $\mathrm{SrO}$ & 0.03 & 0.02 & 0.00 & 0.00 & 0.01 & 0.00 & 0.00 & 0.02 & 0.02 \\
\hline $\mathrm{F}$ & 0.04 & 0.05 & 0.39 & 0.22 & 0.47 & 0.35 & 0.00 & 0.23 & 0.30 \\
\hline $\mathrm{Cl}$ & 0.05 & 0.04 & 0.00 & 0.01 & 0.08 & 0.00 & 0.00 & 0.03 & 0.00 \\
\hline $\mathrm{H}_{2} \mathrm{O}^{5}$ & 1.96 & 1.98 & 1.96 & 2.01 & 1.89 & 1.92 & 2.13 & 1.93 & 1.99 \\
\hline subtotal & 100.33 & 100.07 & 100.03 & 100.39 & 100.59 & 100.62 & 100.35 & 99.58 & 99.72 \\
\hline$-\mathrm{O}=\mathrm{F}+\mathrm{Cl}$ & -0.03 & -0.03 & 0.00 & -0.01 & -0.05 & 0.00 & 0.00 & -0.02 & 0.00 \\
\hline total & 100.30 & 100.04 & 100.03 & 100.38 & 100.54 & 100.62 & 100.35 & 99.56 & 99.72 \\
\hline $\begin{array}{l}\text { IV } \mathrm{Si} \\
\text { (apfu) }\end{array}$ & 6.31 & 6.74 & 7.68 & 7.74 & 7.53 & 7.40 & 7.86 & 7.51 & 7.82 \\
\hline${ }^{\mathrm{IV}} \mathrm{Al}$ & 1.69 & 1.26 & 0.32 & 0.25 & 0.46 & 0.60 & 0.14 & 0.49 & 0.17 \\
\hline$\sum(\mathrm{IV})$ & 8.00 & 8.00 & 8.00 & 8.00 & 8.00 & 8.00 & 8.00 & 8.00 & 8.00 \\
\hline${ }^{\mathrm{V}} \mathrm{Al}$ & 0.27 & 0.22 & 0.10 & 0.00 & 0.00 & 0.11 & 0.16 & 0.01 & 0.02 \\
\hline${ }^{\mathrm{VI}} \mathrm{Fe}^{3+}$ & 0.69 & 0.61 & 0.11 & 0.29 & 0.51 & 0.49 & 0.00 & 0.41 & 0.12 \\
\hline${ }^{\mathrm{VI}} \mathrm{Fe}^{2+}$ & 1.64 & 1.46 & 0.62 & 0.78 & 0.42 & 0.95 & 1.06 & 1.26 & 0.65 \\
\hline${ }^{\mathrm{VI}} \mathrm{Mn}^{2+}$ & 0.05 & 0.06 & 0.01 & 0.05 & 0.06 & 0.09 & 0.03 & 0.06 & 0.02 \\
\hline${ }^{{ }^{\mathrm{V}} \mathrm{Mg}}$ & 2.15 & 2.52 & 4.15 & 3.85 & 3.93 & 3.31 & 3.74 & 3.25 & 4.16 \\
\hline${ }^{\mathrm{VI}} \mathrm{V}$ & 0.00 & 0.00 & 0.00 & 0.00 & 0.00 & 0.00 & 0.00 & 0.01 & 0.00 \\
\hline${ }^{{ }^{\mathrm{V}} \mathrm{Ti}}$ & 0.18 & 0.12 & 0.01 & 0.02 & 0.06 & 0.04 & 0.00 & 0.01 & 0.01 \\
\hline$\sum(\mathrm{VI})$ & 5.00 & 5.00 & 5.00 & 5.00 & 5.00 & 5.00 & 5.00 & 5.00 & 5.00 \\
\hline
\end{tabular}




\begin{tabular}{|c|c|c|c|c|c|c|c|c|c|}
\hline${ }^{\mathrm{VIII}} \mathrm{Ca}$ & 1.90 & 1.88 & 1.99 & 1.91 & 1.77 & 1.86 & 1.93 & 1.94 & 1.97 \\
\hline 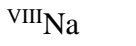 & 0.10 & 0.12 & 0.01 & 0.09 & 0.22 & 0.14 & 0.07 & 0.06 & 0.03 \\
\hline$\sum(\mathrm{VIII})$ & 2.00 & 2.00 & 2.00 & 2.00 & 1.99 & 2.00 & 2.00 & 2.00 & 2.00 \\
\hline${ }^{\mathrm{A}} \mathrm{Na}$ & 0.25 & 0.17 & 0.09 & 0.00 & 0.00 & 0.00 & 0.02 & 0.08 & 0.01 \\
\hline${ }^{\mathrm{A}} \mathrm{Ca}$ & 0.00 & 0.00 & 0.00 & 0.00 & 0.00 & 0.00 & 0.00 & 0.00 & 0.00 \\
\hline${ }^{\mathrm{A}} \mathrm{K}$ & 0.19 & 0.11 & 0.01 & 0.02 & 0.06 & 0.05 & 0.02 & 0.03 & 0.02 \\
\hline${ }^{\mathrm{A}} \mathrm{Sr}$ & 0.00 & 0.00 & 0.00 & 0.00 & 0.00 & 0.00 & 0.00 & 0.00 & 0.00 \\
\hline $\mathrm{A}_{\mathrm{vac}}$ & 0.56 & 0.71 & 0.90 & 0.98 & 0.94 & 0.94 & 0.96 & 0.89 & 0.97 \\
\hline$\sum(\mathrm{A})$ & 1.00 & 1.00 & 1.00 & 1.00 & 1.00 & 1.00 & 1.00 & 1.00 & 1.00 \\
\hline $\mathrm{OH}^{5}$ & 1.97 & 1.97 & 1.83 & 1.90 & 1.77 & 1.84 & 2.00 & 1.88 & 1.87 \\
\hline F & 0.02 & 0.02 & 0.17 & 0.10 & 0.21 & 0.16 & 0.00 & 0.11 & 0.13 \\
\hline $\mathrm{Cl}$ & 0.01 & 0.01 & 0.00 & 0.00 & 0.02 & 0.00 & 0.00 & 0.01 & 0.00 \\
\hline $\mathrm{O}$ & 0.00 & 0.00 & 0.00 & 0.00 & 0.00 & 0.00 & 0.00 & 0.00 & 0.00 \\
\hline$\sum(" \mathrm{OH} ")$ & 2.00 & 2.00 & 2.00 & 2.00 & 2.00 & 2.00 & 2.00 & 2.00 & 2.00 \\
\hline
\end{tabular}

1Locality: Ajo = New Cornelia quartz diorite along the Gibson Arroyo fault. SC = Sycamore Canyon. CMD = Central mining district. $\mathrm{EP}=$ Eagle Pass. $\mathrm{KR}=$ Kelvin-Riverside

2Mineral: Tsch $=$ tschermakite, F-tsch $=$ Ferro-tschermakite, $\mathrm{Mg}$-Hbl = magnesiohornblende, Act $=$ Actinolite, $\mathrm{Tr}=\mathrm{Tremolite}$

3H.A. = hydrothermal assemblage. Act = actinolite; $\mathrm{Ep}=$ epidote; $\mathrm{Ap}=$ apatite; $\mathrm{Ttn}=$ titanite; Rut $=$ rutile; $\mathrm{Chl}=\mathrm{chlorite} ; \mathrm{Px}=$ pyroxene; $\mathrm{Grt}=$ garnet; $\mathrm{Ab}=$ albite; Olig = oligoclase; And = andesine.

4 all Fe originally measured as $\mathrm{Fe}^{2+} . \mathrm{Fe}_{2} \mathrm{O}_{3}$ and $\mathrm{FeO}$ (and $\mathrm{Fe}^{3+}$ and $\mathrm{Fe}^{2+}$ apfu) calculated by charge balance.

$5 \mathrm{H}_{2} \mathrm{O}$ wt\% and $\mathrm{OH}$ apfu calculated by stoichiometry. 
Table 5. Representative analyses of hydrothermal pyroxene (normalized to 4 cations) and garnet (normalized to 8 cations)

$\begin{array}{cccccccc}\text { Locality } & \begin{array}{c}\text { Central } \\ \text { mining } \\ \text { district }\end{array} & \begin{array}{c}\text { Central } \\ \text { mining } \\ \text { district }\end{array} & \text { Silver Bell } & \text { Silver Bell } & \begin{array}{c}\text { Kelvin- } \\ \text { Riverside }\end{array} & \begin{array}{c}\text { Kelvin- } \\ \text { Riverside }\end{array} & \begin{array}{c}\text { Kelvin- } \\ \text { Riverside }\end{array} \\ \text { Mineral } & \text { Diopside } & \text { Diopside } & \text { Diopside } & \text { Diopside } & \text { Andradite } & \text { Andradite } & \text { Andradite }\end{array}$

Sample $\quad \begin{aligned} & \text { CMD- } \\ & \text { C43a }\end{aligned}$

UTM

H.A

And-OligSVB12a SVB12a

$448694 \mathrm{E}$ $3588106 \mathrm{~N}$

448694E

\section{KR-6a}

KR-6a

KR-6a

$\mathrm{SiO}_{2}$ Act

And-Olig-

And-Olig-

$3588106 \mathrm{~N}$

$494337 \mathrm{E}$

494337E $3658757 \mathrm{~N} \quad 3658757 \mathrm{~N}$

494337E

And-OligAct Act

Olig-Ep

Olig-Ep

\begin{tabular}{|c|c|c|c|c|c|c|c|}
\hline (wt\%) & 53.45 & 52.21 & 52.57 & 52.87 & 35.04 & 35.18 & 36.34 \\
\hline $\mathrm{TiO}_{2}$ & 0.09 & 0.19 & 0.08 & 0.02 & 1.21 & 1.00 & 0.88 \\
\hline $\mathrm{Al}_{2} \mathrm{O}_{3}$ & 0.63 & 1.21 & 0.73 & 0.87 & 6.18 & 6.35 & 5.63 \\
\hline $\mathrm{V}_{2} \mathrm{O}_{3}$ & 0.03 & 0.04 & 0.07 & 0.07 & 0.04 & 0.04 & 0.04 \\
\hline $\mathrm{Fe}_{2} \mathrm{O}_{3}{ }^{2}$ & 0.70 & 2.05 & 1.45 & 1.11 & 21.67 & 21.05 & 18.98 \\
\hline $\mathrm{FeO}^{*}$ & 5.46 & 7.89 & 7.74 & 6.88 & 1.43 & 4.53 & 3.73 \\
\hline $\mathrm{MnO}$ & 0.37 & 0.51 & 0.67 & 0.90 & 2.19 & 2.48 & 2.55 \\
\hline $\mathrm{MgO}$ & 14.52 & 12.55 & 12.42 & 12.82 & 0.09 & 0.09 & 0.10 \\
\hline $\mathrm{CaO}$ & 24.36 & 22.73 & 23.48 & 23.90 & 30.76 & 30.45 & 29.55 \\
\hline $\mathrm{Na}_{2} \mathrm{O}$ & 0.23 & 0.59 & 0.50 & 0.43 & 0.00 & 0.00 & 0.01 \\
\hline $\mathrm{K}_{2} \mathrm{O}$ & 0.01 & 0.00 & 0.00 & 0.00 & 0.00 & 0.00 & 0.01 \\
\hline $\mathrm{Sc}_{2} \mathrm{O}_{3}$ & 0.03 & 0.02 & 0.02 & 0.02 & 0.03 & 0.03 & 0.03 \\
\hline $\mathrm{SrO}$ & 0.02 & 0.02 & 0.01 & 0.02 & 0.01 & 0.01 & 0.01 \\
\hline $\mathrm{P}_{2} \mathrm{O}_{5}$ & 0.03 & 0.02 & 0.02 & 0.02 & 0.03 & 0.03 & 0.03 \\
\hline Total & 99.95 & 100.05 & 99.76 & 99.94 & 98.79 & 98.38 & 97.96 \\
\hline${ }^{\text {IV }} \mathrm{Si} \mathrm{(apfu)}$ & 1.98 & 1.96 & 1.98 & 1.98 & 2.93 & 2.95 & 3.00 \\
\hline${ }^{\mathrm{IV}} \mathrm{Al}$ & 0.02 & 0.04 & 0.02 & 0.02 & 0.07 & 0.05 & 0.00 \\
\hline$\sum(\mathrm{IV})$ & 2.00 & 2.00 & 2.00 & 2.00 & 3.00 & 3.00 & 3.00 \\
\hline${ }^{\mathrm{v}} \mathrm{Al}$ & 0.01 & 0.01 & 0.01 & 0.02 & 0.54 & 0.58 & 0.56 \\
\hline${ }^{\mathrm{VI}} \mathrm{Fe}^{3+}$ & 0.02 & 0.06 & 0.04 & 0.03 & 1.36 & 1.33 & 1.20 \\
\hline${ }^{\mathrm{VI}} \mathrm{Fe}^{2+}$ & 0.17 & 0.22 & 0.24 & 0.22 & 0.00 & 0.00 & 0.00 \\
\hline${ }^{\mathrm{VI}} \mathrm{Mg}$ & 0.80 & 0.70 & 0.70 & 0.71 & 0.00 & 0.00 & 0.00 \\
\hline${ }^{\mathrm{VI}} \mathrm{Ti}$ & 0.00 & 0.01 & 0.00 & 0.00 & 0.08 & 0.06 & 0.06 \\
\hline$\sum(\mathrm{VI})$ & 1.00 & 1.00 & 1.00 & 1.00 & 1.98 & 1.97 & 1.82 \\
\hline${ }^{\mathrm{VIIII}} \mathrm{Ca}$ & 0.97 & 0.91 & 0.95 & 0.96 & 2.75 & 2.73 & 2.66 \\
\hline${ }^{\mathrm{VIII}} \mathrm{Na}$ & 0.02 & 0.04 & 0.04 & 0.03 & 0.00 & 0.00 & 0.00 \\
\hline${ }_{\mathrm{VIII}}^{\mathrm{Fe}} \mathrm{Fe}^{2}$ & 0.00 & 0.03 & 0.00 & 0.00 & 0.10 & 0.11 & 0.26 \\
\hline VIII $\mathrm{Mn}^{2+}$ & 0.01 & 0.02 & 0.02 & 0.01 & 0.16 & 0.18 & 0.08 \\
\hline$\sum(\mathrm{VIII})$ & 1.00 & 1.00 & 1.00 & 1.00 & 3.01 & 3.02 & 3.00 \\
\hline
\end{tabular}

${ }^{1}$ H.A. $=$ hydrothermal assemblage. Act $=$ actinolite; $\mathrm{Ep}=$ epidote; $\mathrm{Ap}=$ apatite; $\mathrm{Ttn}=$ titanite; Rut $=$ rutile; $\mathrm{Chl}=$ chlorite $\mathrm{Ksp}=$ K-feldspar; Px = pyroxene; Grt = garnet; $\mathrm{Ab}=$ albite; Olig = oligoclase; And = andesine

${ }^{2}$ all $\mathrm{Fe}$ originally measured as $\mathrm{Fe}^{2+} . \mathrm{Fe}_{2} \mathrm{O}_{3}$ and $\mathrm{FeO}\left(\right.$ and $\mathrm{Fe}^{3+}$ and $\mathrm{Fe}^{2+}$ apfu) calculated by charge balance. 
1181 Table 6. Representative analyses of hydrothermal epidote normalized to 8 cations

\begin{tabular}{|c|c|c|c|c|c|c|c|}
\hline Locality & Eagle Pass & $\begin{array}{l}\text { Kelvin- } \\
\text { Riverside }\end{array}$ & $\begin{array}{l}\text { Sycamore } \\
\text { Canyon }\end{array}$ & Ajo & Sierrita & $\begin{array}{c}\text { Central mining } \\
\text { district }\end{array}$ & $\begin{array}{c}\text { Kelvin- } \\
\text { Riverside }\end{array}$ \\
\hline Sample & SP029 & $\mathrm{NaCa}$ & SC16-7 & Ajo16-1 & NS-2f & CMD-43b & KR-6a \\
\hline UTM & & & $\begin{array}{c}520329 \mathrm{E} \\
3530621 \mathrm{~N}\end{array}$ & $\begin{array}{c}322716 \mathrm{E} \\
3582335 \mathrm{~N}\end{array}$ & $\begin{array}{c}491116 \mathrm{E} \\
3529518 \mathrm{~N}\end{array}$ & & $\begin{array}{c}494337 \mathrm{E} \\
3658757 \\
\mathrm{~N}\end{array}$ \\
\hline H.A. ${ }^{1}$ & $\begin{array}{l}\text { Ab-Chl } \\
\text { vein }\end{array}$ & Olig-Act vein & $\begin{array}{l}\text { Ab-Chl } \\
\text { vein }\end{array}$ & $\mathrm{Ab}-\mathrm{Chl}$ vein & $\begin{array}{l}\text { Olig-Chl } \\
\text { repl. }\end{array}$ & $\begin{array}{l}\text { Ab-Chl } \\
\text { vein }\end{array}$ & $\begin{array}{l}\text { Grt-Ap- } \\
\text { Ttn repl. }\end{array}$ \\
\hline $\mathrm{SiO}_{2}$ & 37.37 & 37.73 & 36.63 & 37.85 & 37.04 & 37.68 & 37 \\
\hline $\mathrm{TiO}_{2}$ & 0.03 & 0.19 & 0.08 & 0.05 & 0.00 & 0.04 & 0.2 \\
\hline $\mathrm{Al}_{2} \mathrm{O}_{3}$ & 23.53 & 22.96 & 21.17 & 25.68 & 20.03 & 22.35 & 25.56 \\
\hline $\mathrm{V}_{2} \mathrm{O}_{3}$ & 0.00 & 0.00 & 0.19 & 0.05 & 0.02 & 0.03 & 0.01 \\
\hline $\mathrm{La}_{2} \mathrm{O}_{3}$ & 0.00 & 0.00 & 0.00 & 0.03 & 0.00 & 0.00 & 0.00 \\
\hline $\mathrm{Ce}_{2} \mathrm{O}_{3}$ & 0.00 & 0.00 & 0.00 & 0.08 & 0.02 & 0.00 & 0.00 \\
\hline $\mathrm{Pr}_{2} \mathrm{O}_{3}$ & 0.00 & 0.00 & 0.00 & 0.01 & 0.00 & 0.01 & 0.00 \\
\hline $\mathrm{Nd}_{2} \mathrm{O}_{3}$ & 0.00 & 0.00 & 0.00 & 0.03 & 0.00 & 0.01 & 0.00 \\
\hline $\mathrm{Gd}_{2} \mathrm{O}_{3}$ & 0.00 & 0.00 & 0.02 & 0.00 & 0.01 & 0.00 & 0.00 \\
\hline $\mathrm{Fe}_{2} \mathrm{O}_{3} *$ & 13.49 & 13.46 & 16.51 & 11.28 & 18.03 & 14.54 & 11.18 \\
\hline $\mathrm{FeO}^{*}$ & 0.00 & 0.19 & 0.00 & 0.00 & 0.14 & 0.34 & 0.00 \\
\hline $\mathrm{Mn}_{2} \mathrm{O}_{3} *$ & 0.25 & 0.00 & 0.28 & 0.00 & 0.00 & 0.00 & 0.72 \\
\hline $\mathrm{MnO}^{*}$ & 0.3 & 0.22 & 0.00 & 0.00 & 0.52 & 0.33 & 0.00 \\
\hline $\mathrm{MgO}$ & 0.03 & 0.00 & 0.02 & 0.08 & 0.00 & 0.03 & 0.01 \\
\hline $\mathrm{CaO}$ & 23.01 & 23.25 & 22.3 & 23.47 & 22.37 & 22.83 & 22.92 \\
\hline $\mathrm{SrO}$ & 0.00 & 0.00 & 0.88 & 0.36 & 0.26 & 0.17 & 0.27 \\
\hline $\mathrm{ThO}_{2}$ & 0.00 & 0.00 & 0.00 & 0.02 & 0.01 & 0.00 & 0.00 \\
\hline $\mathrm{Sc}_{2} \mathrm{O}_{3}$ & 0.00 & 0.00 & 0.02 & 0.01 & 0.02 & 0.00 & 0.02 \\
\hline $\mathrm{Cr}_{2} \mathrm{O}_{3}$ & 0.00 & 0.00 & 0.02 & 0.02 & 0.01 & 0.01 & 0.01 \\
\hline HREE $^{3}$ & 0.00 & 0.00 & 0.00 & 0.00 & 0.01 & 0.00 & 0.00 \\
\hline $\mathrm{Na}_{2} \mathrm{O}$ & 0.00 & 0.00 & 0.00 & 0.00 & 0.00 & 0.01 & 0.00 \\
\hline $\mathrm{F}$ & 0.15 & 0.00 & 0.00 & 0.00 & 0.00 & 0.00 & 0.01 \\
\hline $\mathrm{Cl}$ & 0.00 & 0.01 & 0.01 & 0.00 & 0.00 & 0.00 & 0.00 \\
\hline $\mathrm{H}_{2} \mathrm{O}^{4}$ & 1.88 & 1.88 & 1.85 & 1.92 & 1.85 & 1.88 & 1.89 \\
\hline subtotal & 100.04 & 99.92 & 99.99 & 100.95 & 100.34 & 100.25 & 99.82 \\
\hline$-\mathrm{O}=\mathrm{F}+\mathrm{Cl}$ & -0.04 & 0.00 & -0.01 & 0.00 & 0.00 & 0.00 & 0.00 \\
\hline total & 100.01 & 99.92 & 99.99 & 100.95 & 100.34 & 100.24 & 99.82 \\
\hline${ }^{\mathrm{IV}} \mathrm{Si}$ (apfu) & 2.98 & 3.01 & 2.96 & 2.96 & 3.00 & 3.01 & 2.93 \\
\hline${ }^{\mathrm{IV}} \mathrm{Al}$ & 0.02 & 0.00 & 0.04 & 0.04 & 0.00 & 0.00 & 0.07 \\
\hline$\sum(\mathrm{IV})$ & 3.00 & 3.01 & 3.00 & 3.00 & 3.00 & 3.01 & 3.00 \\
\hline${ }^{\mathrm{VI}} \mathrm{Al}$ & 2.18 & 2.17 & 2.00 & 2.33 & 1.90 & 2.11 & 2.31 \\
\hline${ }^{\mathrm{V}} \mathrm{Fe}^{3+}$ & 0.81 & 0.81 & 0.98 & 0.66 & 0.99 & 0.87 & 0.67 \\
\hline${ }^{\mathrm{VI}} \mathrm{Mn}^{3+}$ & 0.01 & 0.00 & 0.02 & 0.00 & 0.00 & 0.00 & 0.04 \\
\hline${ }^{\mathrm{VI}} \mathrm{Fe}^{2+}$ & 0.00 & 0.01 & 0.00 & 0.00 & 0.00 & 0.00 & 0.00 \\
\hline${ }^{\mathrm{VI}} \mathrm{Mg}$ & 0.00 & 0.00 & 0.00 & 0.01 & 0.00 & 0.00 & 0.00 \\
\hline
\end{tabular}




\begin{tabular}{|c|c|c|c|c|c|c|c|}
\hline${ }^{{ }^{\mathrm{I}} \mathrm{Ti}}$ & 0.00 & 0.01 & 0.00 & 0.00 & 0.00 & 0.00 & 0.01 \\
\hline$\sum(\mathrm{VI})$ & 3.00 & 3.00 & 3.00 & 3.00 & 3.00 & 3.00 & 3.00 \\
\hline${ }^{\mathrm{A}} \mathrm{Ca}$ & 2.00 & 1.99 & 1.96 & 1.97 & 1.93 & 1.96 & 1.95 \\
\hline${ }^{\mathrm{A}} \mathrm{Sr}$ & 0.00 & 0.00 & 0.04 & 0.02 & 0.01 & 0.01 & 0.01 \\
\hline${ }^{\mathrm{A}} \mathrm{Mn}^{2+}$ & 0.00 & 0.00 & 0.00 & 0.00 & 0.04 & 0.02 & 0.00 \\
\hline${ }^{\mathrm{A}} \mathrm{Fe}^{2+}$ & 0.00 & 0.01 & 0.00 & 0.00 & 0.01 & 0.02 & 0.00 \\
\hline${ }^{\mathrm{A}} \mathrm{Mg}$ & 0.00 & 0.00 & 0.00 & 0.01 & 0.00 & 0.00 & 0.00 \\
\hline$\sum(\mathrm{A})$ & 2.00 & 2.00 & 2.00 & 2.00 & 2.00 & 2.00 & 2.00 \\
\hline${ }^{\mathrm{O} 10} \mathrm{OH}^{4}$ & 1.00 & 1.00 & 1.00 & 1.00 & 1.00 & 1.00 & 1.00 \\
\hline${ }^{\mathrm{O}} \mathrm{F}$ & 0.04 & 0.00 & 0.00 & 0.00 & 0.00 & 0.00 & 0.00 \\
\hline${ }^{04} \mathrm{O}$ & 0.96 & 1.00 & 1.00 & 1.00 & 1.00 & 1.00 & 1.00 \\
\hline$\sum(\mathrm{O} 4)$ & 1.00 & 1.00 & 1.00 & 1.00 & 1.00 & 1.00 & 1.00 \\
\hline
\end{tabular}

Trace elements $(\mu \mathrm{g} / \mathrm{g})^{5}$

No.

\begin{tabular}{|c|c|c|c|}
\hline Analyses $^{6}$ & 11 & 11 & 11 \\
\hline Li7 & $<4$ & $<5$ & $<4$ \\
\hline Be9 & $<3$ & $<6$ & $<3$ \\
\hline B11 & 8 & $<7$ & $<5$ \\
\hline $\mathrm{Mg} 24$ & 902 & 785 & 1310 \\
\hline Sc45 & 8 & 11 & 34 \\
\hline Ti48 & 737 & 1022 & 725 \\
\hline V51 & 310 & 349 & 158 \\
\hline Cr53 & 10 & 6 & 8 \\
\hline Mn55 & 1136 & 1050 & 2523 \\
\hline $\mathrm{Fe} 57$ & 87416 & 96077 & 90855 \\
\hline Ni60 & $<19$ & $<25$ & $<20$ \\
\hline $\mathrm{Cu} 65$ & 2 & 2 & 4 \\
\hline Zn66 & 4 & 10 & 12 \\
\hline Ga69 & 60 & 77 & 46 \\
\hline Ga71 & 58 & 74 & 52 \\
\hline Ge72 & 8 & 36 & 28 \\
\hline Sr88 & 3770 & 1179 & 860 \\
\hline Y89 & 7 & 16 & 185 \\
\hline Sn118 & 5 & 65 & 17 \\
\hline La139 & 4 & 28 & 192 \\
\hline $\mathrm{Ce} 140$ & 12 & 45 & 460 \\
\hline Pr141 & 2 & 5 & 53 \\
\hline Nd144 & 8 & 17 & 181 \\
\hline Sm147 & 2 & 4 & 42 \\
\hline Eu151 & 1 & 5 & 8 \\
\hline Gd157 & 2 & 4 & 35 \\
\hline Tb159 & 0 & 1 & 5 \\
\hline Dy163 & 1 & 3 & 34 \\
\hline
\end{tabular}


Er167

\section{1}

Yb173

Pb204

Pb206

26

Pb207

$\mathrm{Pb} 208$

Th232

1H.A. $=$ hydrothermal assemblage. Act $=$ actinolite; $\mathrm{Ep}=$ epidote; $\mathrm{ap}=$ apatite; $\mathrm{ttn}=$ titanite; rut $=$ rutile; chl $=$ chlorite; $\mathrm{ksp}=\mathrm{K}-$ feldspar; $\mathrm{Px}=$ pyroxene; grt = garnet; $\mathrm{Ab}=$ albite; olig = oligoclase; and = andesine. Repl. = wall rock replacement. measured as $\mathrm{Mn}^{+2} \cdot \mathrm{Mn}_{2} \mathrm{O}_{3}$ and $\mathrm{MnO}$ (and $\mathrm{Mn}^{3+}$ and $\mathrm{Mn}^{2+}$ apfu) calculated by charge balance 3 HREE content here estimated from EPMA light rare earth element patterns.

$4 \mathrm{H}_{2} \mathrm{O}$ wt $\%$ and $\mathrm{OH}$ apfu calculated by stoichiometry.

Elements analyzed for that did not comprise $>0.00 \mathrm{wt} \%$ oxide include $\mathrm{Sm}, \mathrm{U}$, and $\mathrm{Y}$.

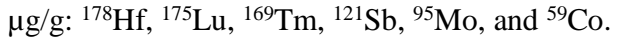


Table 7. Representative analyses of hydrothermal apatite normalized to 8 cations

\begin{tabular}{|c|c|c|c|c|c|c|c|}
\hline Locality & Ajo & Charleston & $\begin{array}{c}\text { Sycamore } \\
\text { Canyon }\end{array}$ & $\begin{array}{l}\text { Silver } \\
\text { Bell }\end{array}$ & $\begin{array}{l}\text { Ninetysix } \\
\text { Hills }\end{array}$ & $\begin{array}{l}\text { Central mining } \\
\text { district }\end{array}$ & Sierrita \\
\hline Sample & Ajo16-1 & T16-1 & SC16-7 & SVB-12a & Che-c1 & CMD-43b & $\mathrm{NS}-2 \mathrm{c}$ \\
\hline \multirow{2}{*}{ UTM } & $322716 \mathrm{E}$ & $579368 \mathrm{E}$ & $520329 \mathrm{E}$ & 448694E & $490081 \mathrm{E}$ & & 491053E \\
\hline & $3582335 \mathrm{~N}$ & $3498023 \mathrm{~N}$ & $3530621 \mathrm{~N}$ & $3588106 \mathrm{~N}$ & $3645219 \mathrm{~N}$ & & $3529517 \mathrm{~N}$ \\
\hline H.A. ${ }^{1}$ & $\begin{array}{c}\text { Ab-Ep- } \\
\text { Chl }\end{array}$ & Ab-Ep-Chl & $\begin{array}{l}\text { Ab-Ep- } \\
\text { Chl }\end{array}$ & $\begin{array}{l}\text { Di-Olig- } \\
\text { Act }\end{array}$ & Ab-Ep-Chl & Ab-Ep-Chl & Olig-Chl \\
\hline $\begin{array}{l}\mathrm{P}_{2} \mathrm{O}_{5} \\
(\mathrm{wt} \%)\end{array}$ & 41.36 & 41.54 & 41.63 & 41.81 & 40.70 & 41.40 & 41.80 \\
\hline $\mathrm{SiO}_{2}$ & 0.26 & 0.38 & 0.25 & 0.30 & 0.47 & 0.34 & 0.44 \\
\hline $\mathrm{La}_{2} \mathrm{O}_{3}$ & 0.09 & 0.12 & 0.10 & 0.05 & 0.12 & 0.15 & 0.26 \\
\hline $\mathrm{Ce}_{2} \mathrm{O}_{3}$ & 0.36 & 0.36 & 0.11 & 0.08 & 0.31 & 0.15 & 0.07 \\
\hline $\mathrm{Pr}_{2} \mathrm{O}_{3}$ & 0.04 & 0.06 & 0.02 & 0.02 & 0.09 & 0.00 & 0.02 \\
\hline $\mathrm{Nd}_{2} \mathrm{O}_{3}$ & 0.10 & 0.22 & 0.06 & 0.00 & 0.02 & 0.04 & 0.04 \\
\hline $\mathrm{Sm}_{2} \mathrm{O}_{3}$ & 0.05 & 0.04 & 0.02 & 0.00 & 0.01 & 0.00 & 0.00 \\
\hline $\mathrm{Gd}_{2} \mathrm{O}_{3}$ & 0.02 & 0.05 & 0.04 & 0.00 & 0.01 & 0.00 & 0.00 \\
\hline $\mathrm{Y}_{2} \mathrm{O}_{3}$ & 0.11 & 0.28 & 0.07 & 0.03 & 0.11 & 0.07 & 0.10 \\
\hline $\mathrm{ThO}_{2}$ & 0.00 & 0.00 & 0.01 & 0.02 & 0.02 & 0.00 & 0.00 \\
\hline $\mathrm{UO}_{2}$ & 0.00 & 0.00 & 0.00 & 0.00 & 0.00 & 0.00 & 0.00 \\
\hline $\mathrm{MnO}$ & 0.01 & 0.10 & 0.11 & 0.06 & 0.15 & 0.06 & 0.07 \\
\hline $\mathrm{CaO}$ & 54.80 & 53.33 & 54.81 & 54.86 & 55.02 & 55.01 & 54.63 \\
\hline $\mathrm{SrO}$ & 0.03 & 0.02 & 0.06 & 0.04 & 0.01 & 0.06 & 0.07 \\
\hline $\mathrm{Na}_{2} \mathrm{O}$ & 0.17 & 0.22 & 0.03 & 0.04 & 0.06 & 0.05 & 0.07 \\
\hline $\mathrm{F}$ & 2.71 & 2.44 & 2.62 & 3.59 & 3.33 & 3.31 & 2.73 \\
\hline $\mathrm{Cl}$ & 0.25 & 1.05 & 0.02 & 0.15 & 0.02 & 0.14 & 0.02 \\
\hline $\mathrm{H}_{2} \mathrm{O}^{2}$ & 0.42 & 0.34 & 0.53 & 0.04 & 0.18 & 0.17 & 0.48 \\
\hline subtotal & 100.84 & 100.64 & 100.56 & 101.64 & 101.76 & 100.94 & 101.64 \\
\hline$-\mathrm{O}=\mathrm{F}+\mathrm{Cl}$ & -0.72 & -0.99 & -0.60 & -0.87 & -0.76 & -0.81 & -0.62 \\
\hline total & 100.12 & 99.64 & 99.96 & 100.87 & 100.88 & 100.13 & 100.87 \\
\hline${ }^{I V} \mathrm{P}$ & & & & & & & \\
\hline (apfu) & 2.96 & 2.99 & 2.97 & 2.98 & 2.93 & 2.96 & 2.98 \\
\hline${ }^{\mathrm{IV}} \mathrm{Si}$ & 0.02 & 0.03 & 0.02 & 0.02 & 0.04 & 0.04 & 0.03 \\
\hline${ }^{\mathrm{IV}} \mathrm{S}$ & 0.01 & 0.00 & 0.01 & 0.00 & 0.01 & 0.00 & 0.01 \\
\hline$\sum(\mathrm{IV})$ & 2.99 & 3.03 & 3.01 & 3.00 & 2.98 & 3.00 & 3.01 \\
\hline${ }^{\mathrm{A}} \mathrm{Ca}$ & 4.97 & 4.86 & 4.95 & 4.95 & 4.99 & 4.99 & 4.93 \\
\hline${ }^{A} \mathrm{Sr}$ & 0.00 & 0.00 & 0.00 & 0.00 & 0.00 & 0.00 & 0.00 \\
\hline${ }^{\mathrm{A}} \mathrm{La}$ & 0.00 & 0.00 & 0.00 & 0.00 & 0.00 & 0.00 & 0.01 \\
\hline${ }^{\mathrm{A}} \mathrm{Ce}$ & 0.01 & 0.02 & 0.00 & 0.00 & 0.00 & 0.00 & 0.01 \\
\hline${ }^{4} \mathrm{Pr}$ & 0.00 & 0.00 & 0.00 & 0.00 & 0.00 & 0.00 & 0.00 \\
\hline${ }^{\mathrm{A}} \mathrm{Nd}$ & 0.00 & 0.02 & 0.00 & 0.00 & 0.00 & 0.00 & 0.00 \\
\hline${ }^{\mathrm{A}} \mathrm{Sm}$ & 0.00 & 0.00 & 0.00 & 0.00 & 0.00 & 0.00 & 0.00 \\
\hline${ }^{\mathrm{A}} \mathrm{Gd}$ & 0.00 & 0.00 & 0.00 & 0.00 & 0.00 & 0.00 & 0.00 \\
\hline${ }^{\mathrm{A}} Y$ & 0.01 & 0.02 & 0.00 & 0.00 & 0.00 & 0.00 & 0.00 \\
\hline${ }^{\mathrm{A}} \mathrm{Th}$ & 0.00 & 0.00 & 0.00 & 0.00 & 0.00 & 0.00 & 0.00 \\
\hline${ }^{\mathrm{A}} \mathrm{U}$ & 0.00 & 0.00 & 0.00 & 0.00 & 0.00 & 0.00 & 0.00 \\
\hline${ }^{4} \mathrm{Mn}^{2+}$ & 0.00 & 0.02 & 0.02 & 0.00 & 0.01 & 0.00 & 0.01 \\
\hline${ }^{\mathrm{A}} \mathrm{Na}$ & 0.01 & 0.05 & 0.02 & 0.03 & 0.01 & 0.01 & 0.01 \\
\hline$\sum(\mathrm{A})$ & 5.00 & 4.99 & 4.99 & 4.98 & 5.01 & 5.00 & 4.97 \\
\hline $\bar{x}_{F}$ & 0.73 & 0.66 & 0.70 & 0.96 & 0.90 & 0.88 & 0.66 \\
\hline${ }^{x} \mathrm{Cl}$ & 0.04 & 0.15 & 0.00 & 0.02 & 0.00 & 0.02 & 0.02 \\
\hline${ }^{x} \mathrm{OH}^{2}$ & 0.24 & 0.19 & 0.30 & 0.02 & 0.10 & 0.10 & 0.33 \\
\hline$\sum(\mathrm{X})$ & 1.00 & 1.00 & 1.00 & 1.00 & 1.00 & 1.00 & 1.00 \\
\hline
\end{tabular}

${ }_{1}^{1}$ H.A. = hydrothermal assemblage. Act = actinolite; $\mathrm{Ep}=$ epidote; ap = apatite; $\mathrm{ttn}=$ titanite; rut $=$ rutile; chl = chlorite; $\mathrm{ksp}=$ $\mathrm{K}$-feldspar; $\mathrm{Px}=$ pyroxene; grt = garnet; $\mathrm{Ab}=$ albite; olig = oligoclase; and = andesine. $\# \mathrm{OH}$ and $\mathrm{H} 2 \mathrm{O}$ calculated by stoichiometry.

$2 \mathrm{H}_{2} \mathrm{O}$ wt $\%$ and $\mathrm{OH}$ apfu calculated by stoichiometry. 
${ }_{5}^{4} 201$ Table 8. Fluid inclusion data of secondary or uncertain origin

5 6
Locality:

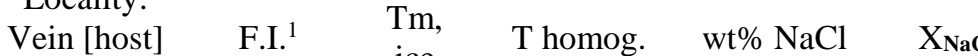
- UTM

\begin{tabular}{|c|c|c|c|c|c|c|c|c|}
\hline \multirow{30}{*}{$\begin{array}{c}\text { Sycamore } \\
\text { Canyon } \\
\text { [epidote] } \\
- \\
520329 \mathrm{E} \\
3530621 \mathrm{~N}\end{array}$} & N.C. & & 324.7 & & & & & \\
\hline & N.C. & & 321.9 & & & & & \\
\hline & N.C. & & 311 & & & & & \\
\hline & N.C. & & 323.5 & & & & & \\
\hline & N.C. & & 323.5 & & & & & \\
\hline & N.C. & -13.9 & $>336$ & 17.7 & 0.06 & 0.94 & $<0.85$ & $>469$ \\
\hline & N.C. & & $>336$ & & & & & \\
\hline & N.C. & & $>336$ & & & & & \\
\hline & N.C. & & $>336$ & & & & & \\
\hline & N.C. & -10.3 & 320.4 & 14.3 & 0.05 & 0.95 & 0.84 & 454 \\
\hline & N.C. & -9.1 & 322.6 & 13.0 & 0.04 & 0.96 & 0.82 & 460 \\
\hline & N.C. & -8 & 322.6 & 11.7 & 0.04 & 0.96 & 0.81 & 463 \\
\hline & N.C. & -4.6 & 324.5 & 7.3 & 0.02 & 0.98 & 0.75 & 478 \\
\hline & N.C. & -4.6 & 321.9 & 7.3 & 0.02 & 0.98 & 0.76 & 474 \\
\hline & N.C. & -9.5 & 327.8 & 13.4 & 0.05 & 0.95 & 0.82 & 467 \\
\hline & Irr. & -3.4 & 311.5 & 5.6 & 0.02 & 0.98 & 0.75 & 462 \\
\hline & Irr. & -2.2 & 319.4 & 3.7 & 0.01 & 0.99 & 0.71 & 483 \\
\hline & Irr. & & $326 \pm 2.5$ & & & & & \\
\hline & Irr. & & $>336$ & & & & & \\
\hline & Irr. & -3.4 & 251.1 & 5.6 & 0.02 & 0.98 & 0.84 & 369 \\
\hline & Irr. & -3.5 & 248.3 & 5.7 & 0.02 & 0.98 & 0.85 & 365 \\
\hline & Irr. & & $>336$ & & & & & \\
\hline & Irr. & & $>336$ & & & & & \\
\hline & Irr. & & $>336$ & & & & & \\
\hline & Irr. & & 191.4 & & & & & \\
\hline & Irr. & & $191 \pm 2.5$ & & & & & \\
\hline & Irr. & & 220.1 & & & & & \\
\hline & Irr. & & 190.5 & & & & & \\
\hline & Irr. & & $209.3 \pm 2.5$ & & & & & \\
\hline & Irr. & & 215.5 & & & & & \\
\hline \multirow{5}{*}{$\begin{array}{c}\text { Sycamore } \\
\text { Canyon } \\
\text { [quartz] } \\
- \\
520329 \mathrm{E} \\
3530621 \mathrm{~N}\end{array}$} & Irr. & & $>336$ & & & & & \\
\hline & Irr. & & 238.7 & & & & & \\
\hline & Irr. & & $182.1 \pm 2.5$ & & & & & \\
\hline & Irr. & & $182.1 \pm 2.5$ & & & & & \\
\hline & Irr. & & 192.3 & & & & & \\
\hline $\begin{array}{c}\text { Locality: } \\
\text { Vein [host] } \\
\text { - UTM }\end{array}$ & F.I. ${ }^{1}$ & $\begin{array}{l}\mathrm{Tm} \\
\text { ice }\end{array}$ & T homog. & $\mathrm{wt} \% \mathrm{NaCl}$ & $\mathrm{X}_{\mathrm{NaCl}}$ & $\mathrm{X}_{\mathrm{H} 2 \mathrm{O}}$ & $\mathrm{r}_{\text {fluid }}$ & $\begin{array}{l}\mathrm{T}\left({ }^{\circ} \mathrm{C}\right) \text { at } \\
\sim 1600 \text { bar }\end{array}$ \\
\hline \multirow{2}{*}{$\begin{array}{l}\text { Sierrita } \\
\text { [quartz] }\end{array}$} & Irr. & -5.7 & $>330$ & 8.8 & 0.03 & 0.97 & $<0.76$ & $>482$ \\
\hline & Irr. & -4.8 & $>330$ & 7.6 & 0.02 & 0.98 & $<0.75$ & $>486$ \\
\hline
\end{tabular}




\begin{tabular}{rlrlrllll}
- & N.C. & -2.5 & $>330$ & 4.2 & 0.01 & 0.99 & $<0.70$ & $>501$ \\
$351053 \mathrm{E} 29517 \mathrm{~N}$ & N.C. & -1 & $>330$ & 1.7 & 0.01 & 0.99 & $<0.67$ & $>518$ \\
& Irr. & -0.4 & $>330$ & 0.7 & 0.00 & 1.00 & $<0.65$ & $>528$ \\
& N.C. & -3.2 & $>330$ & 5.3 & 0.02 & 0.98 & $<0.72$ & $>496$ \\
& Irr. & -0.6 & $>330$ & 1.1 & 0.00 & 1.00 & $<0.66$ & $>524$ \\
& Irr. & -3.1 & $>330$ & 5.1 & 0.02 & 0.98 & $<0.72$ & $>497$ \\
& Irr. & -3.7 & $>330$ & 6 & 0.02 & 0.98 & $<0.73$ & $>493$ \\
& Irr. & -1.1 & $>330$ & 1.9 & 0.01 & 0.99 & $<0.67$ & $>517$ \\
& Irr. & -3.4 & $>330$ & 5.6 & 0.02 & 0.98 & $<0.72$ & $>494$ \\
& Irr. & -2.2 & $>330$ & 3.7 & 0.01 & 0.99 & $<0.70$ & $>504$ \\
& Irr. & -2.2 & $>330$ & 3.7 & 0.01 & 0.99 & $<0.70$ & $>504$ \\
& Irr. & -1.8 & $>330$ & 3.1 & 0.01 & 0.99 & $<0.69$ & $>508$ \\
\hline Locality: & & $\mathrm{Tm}$ & & & & & & $\mathrm{T}\left({ }^{\circ} \mathrm{C}\right)$ at
\end{tabular}

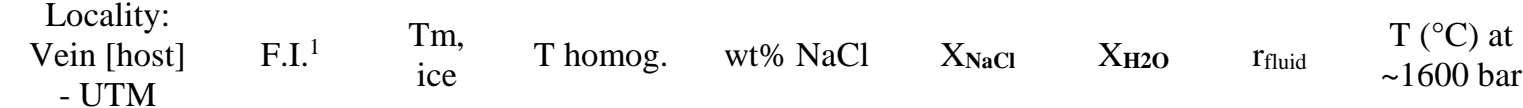


${ }_{5}^{4} 1204$ Table 9. $\delta \mathrm{D}$ Compositions of igneous and alteration minerals

\begin{tabular}{|c|c|c|c|c|c|c|c|c|}
\hline District & Sample & UTM & Occurrence & Mineral & $\mathbf{T}^{\circ} \mathbf{C}^{\mathbf{1}}$ & $\mathrm{XMg}^{2}$ & $\begin{array}{l}\delta D \% \\
\text { Min }\end{array}$ & $\begin{array}{l}\delta D^{2} \% \\
\mathrm{H}_{2} \mathrm{O}^{3}\end{array}$ \\
\hline \multirow{5}{*}{$\begin{array}{l}\text { Ajo, } \\
\text { Arizona }\end{array}$} & Ajo-Act & 324192E & $\begin{array}{l}\text { Chlorite from albite- } \\
\text { chlorite-epidote vein in pit }\end{array}$ & chlorite & 200 & 0.69 & -82 & 12 \\
\hline & Ajo-ep & $3582005 \mathrm{~N}$ & $\begin{array}{l}\text { Epidote from albite- } \\
\text { chlorite-epidote vein in pit }\end{array}$ & epidote & 300 & & -85 & -27 \\
\hline & Ajo-igb & $\begin{array}{c}324267 \mathrm{E} \\
3582075 \mathrm{~N}\end{array}$ & $\begin{array}{l}\text { Chlorite-altered biotite } \\
\text { from New Cornelia quartz } \\
\text { monzonite }\end{array}$ & chlorite & 200 & 0.45 & -101 & -6 \\
\hline & $\begin{array}{l}\text { Ajo- } \\
\text { coCh1 }\end{array}$ & $\begin{array}{c}324295 \mathrm{E} \\
3582096 \mathrm{~N}\end{array}$ & $\begin{array}{l}\text { Chlorite replacing coarse } \\
\text { biotite in pegmatite dike }\end{array}$ & chlorite & 200 & 0.45 & -106 & -11 \\
\hline & GA-ep & $\begin{array}{l}322716 \mathrm{E} \\
3582335 \mathrm{~N}\end{array}$ & $\begin{array}{l}\text { Epidote vein from } \mathrm{Na}-\mathrm{Ca} \\
\text { along Gibson Arroyo }\end{array}$ & epidote & 300 & & -82 & -24 \\
\hline \multirow{5}{*}{$\begin{array}{l}\text { Sierrita, } \\
\text { Arizona }\end{array}$} & NS-pegb & $\begin{array}{c}481748 \mathrm{E} \\
3534871 \mathrm{~N}\end{array}$ & $\begin{array}{c}\text { Biotite from pegmatite } \\
\text { dike }\end{array}$ & biotite & 700 & 0.57 & -59 & -34 \\
\hline & NS-igb & $\begin{array}{c}481348 \mathrm{E} \\
3536829 \mathrm{~N}\end{array}$ & $\begin{array}{l}\text { Igneous biotite from } \\
\text { granodiorite }\end{array}$ & biotite & 700 & 0.57 & -75 & -50 \\
\hline & NS-ep & $491053 \mathrm{E}$ & $\begin{array}{l}\text { Epidote from actinolite- } \\
\text { epidote-plagioclase vein }\end{array}$ & epidote & 300 & & -93 & -30 \\
\hline & NS-Act & $3529517 \mathrm{~N}$ & $\begin{array}{c}\text { Actinolite from vein } \\
\text { envelope }\end{array}$ & actinolite & 300 & 0.45 & -88 & -23 \\
\hline & NS-peg-m & $\begin{array}{c}481748 \mathrm{E} \\
3534871 \mathrm{~N}\end{array}$ & $\begin{array}{l}\text { Muscovite from pegmatite } \\
\text { dike }\end{array}$ & muscovite & 700 & 0.14 & -67 & -63 \\
\hline \multirow{3}{*}{$\begin{array}{l}\text { Silver Bell, } \\
\text { Arizona }\end{array}$} & SVB-igbt & $\begin{array}{c}448590 \mathrm{E} \\
3588141 \mathrm{~N}\end{array}$ & $\begin{array}{l}\text { Igneous biotite from } \\
\text { quartz monzonite }\end{array}$ & biotite & 700 & 0.57 & -87 & -57 \\
\hline & SVB-act & 448694E & $\begin{array}{l}\text { Actinolite from } \\
\text { plagioclase-actinolite vein }\end{array}$ & actinolite & 300 & 0.65 & -82 & -37 \\
\hline & SVB-chl & $3588106 \mathrm{~N}$ & $\begin{array}{l}\text { Chlorite from plagioclase- } \\
\text { actinolite-chlorite vein }\end{array}$ & chlorite & 300 & 0.65 & -82 & -39 \\
\hline \multirow{2}{*}{$\begin{array}{l}\text { Sycamore } \\
\text { Canyon, } \\
\text { Arizona }\end{array}$} & SC-epv & $\begin{array}{c}520329 \mathrm{E} \\
3530621 \mathrm{~N}\end{array}$ & $\begin{array}{c}\text { Epidote from albite- } \\
\text { epidote-chlorite alteration }\end{array}$ & epidote & 200 & & -74 & -1 \\
\hline & scf-igb & $\begin{array}{c}520273 \mathrm{E} \\
3530897 \mathrm{~N}\end{array}$ & $\begin{array}{l}\text { Chlorite after igneous } \\
\text { biotite }\end{array}$ & chlorite & 200 & 0.45 & -95 & 0 \\
\hline \multirow{2}{*}{$\begin{array}{l}\text { Charleston, } \\
\text { Arizona }\end{array}$} & T16-5be & $\begin{array}{c}579368 \mathrm{E} \\
3498023 \mathrm{~N}\end{array}$ & $\begin{array}{l}\text { Epidote from albite- } \\
\text { epidote-chlorite vein }\end{array}$ & epidote & 200 & & -82 & -12 \\
\hline & T16-1ac & $\begin{array}{c}579076 \mathrm{E} \\
3498592 \mathrm{~N} \\
\end{array}$ & $\begin{array}{l}\text { Chlorite from albite- } \\
\text { epidote-chlorite vein }\end{array}$ & chlorite & 200 & 0.98 & -96 & -19 \\
\hline \multirow{2}{*}{$\begin{array}{l}\text { Kelvin } \\
\text { Riverside, } \\
\text { Arizona }\end{array}$} & KR-igb & $\begin{array}{c}494430 \mathrm{E} \\
3658332 \mathrm{~N}\end{array}$ & Igneous biotite & biotite & 700 & 0.57 & -87 & -62 \\
\hline & KR-rep & $\begin{array}{l}495039 \mathrm{E} \\
3658904 \mathrm{~N}\end{array}$ & $\begin{array}{l}\text { Epidote (pervasive Na- } \\
\text { Ca) in Ruin Granite }\end{array}$ & epidote & 450 & & -90 & -46 \\
\hline \multirow{4}{*}{$\begin{array}{l}\text { Luhr Hill, } \\
\text { Yerington, } \\
\text { Nevada }\end{array}$} & LH2-igb & $\begin{array}{c}316089 \mathrm{E} \\
4314437 \mathrm{~N}\end{array}$ & $\begin{array}{l}\text { Chlorite after igneous } \\
\text { biotite }\end{array}$ & chlorite & 200 & 0.45 & -96 & -2 \\
\hline & LH-vep & $\begin{array}{l}315951 \mathrm{E} \\
4314576 \mathrm{~N}\end{array}$ & $\begin{array}{l}\text { Epidote envelope on } \\
\text { oligoclase vein }\end{array}$ & epidote & 400 & & -101 & -58 \\
\hline & LH-mep & $\begin{array}{l}315758 \mathrm{E} \\
4314900 \mathrm{~N}\end{array}$ & Epidote-actinolite vein & epidote & 400 & & -99 & -56 \\
\hline & LH-mact & $\begin{array}{l}315254 \mathrm{E} \\
4314431 \mathrm{~N}\end{array}$ & $\begin{array}{l}\text { Massive actinolite- } \\
\text { feldspar }\end{array}$ & actinolite & 400 & 0.63 & -91 & -45 \\
\hline
\end{tabular}




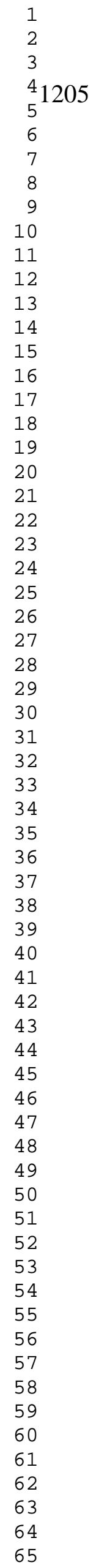


Figure 1

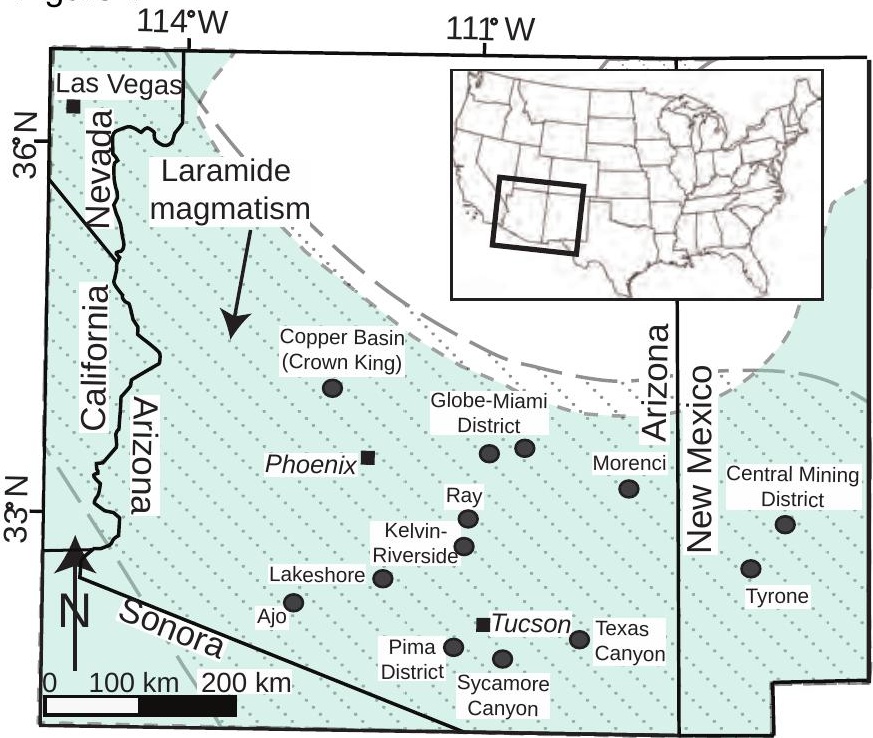




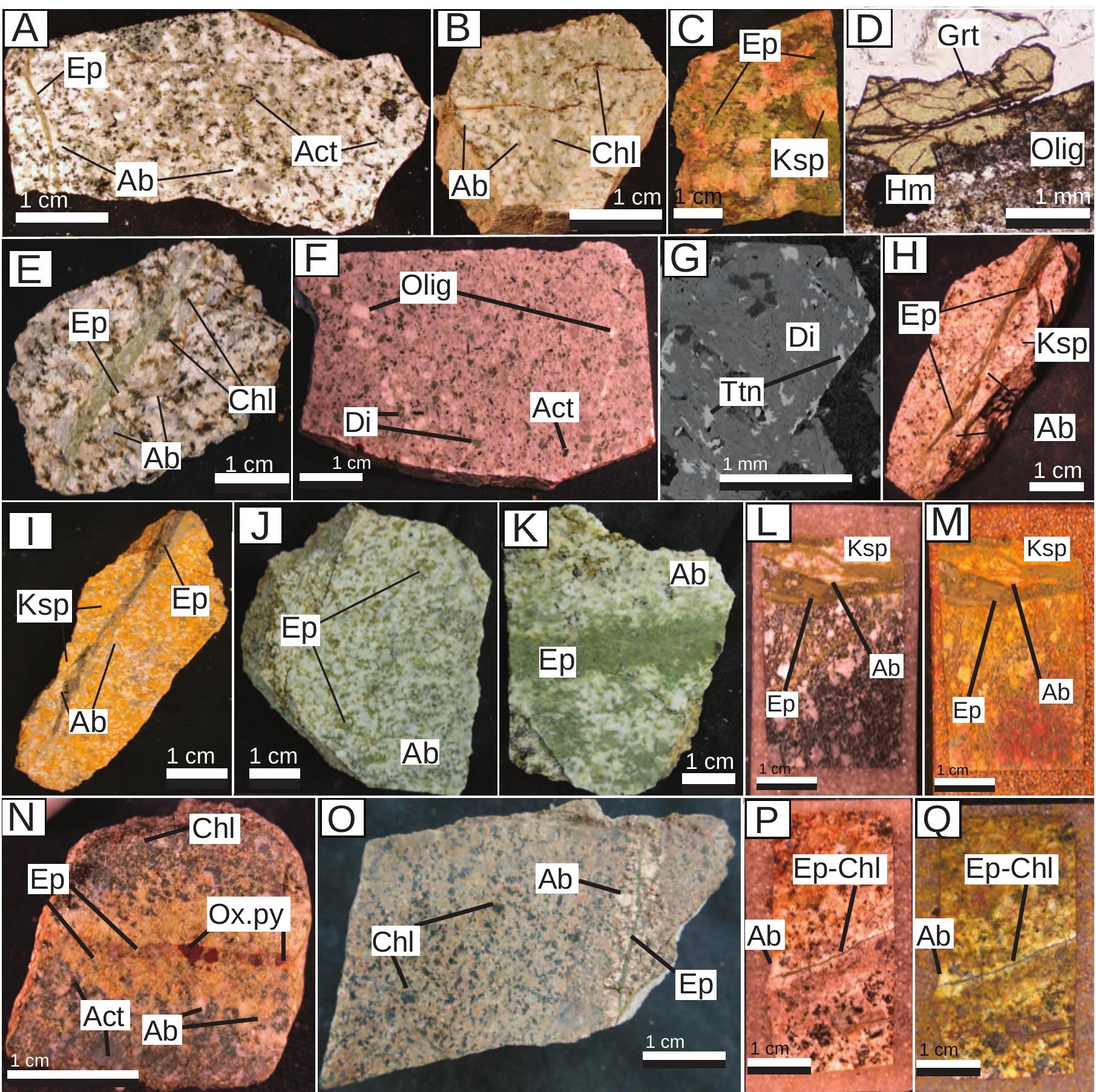



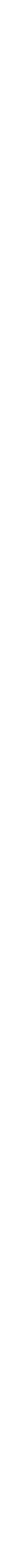
Figure 4
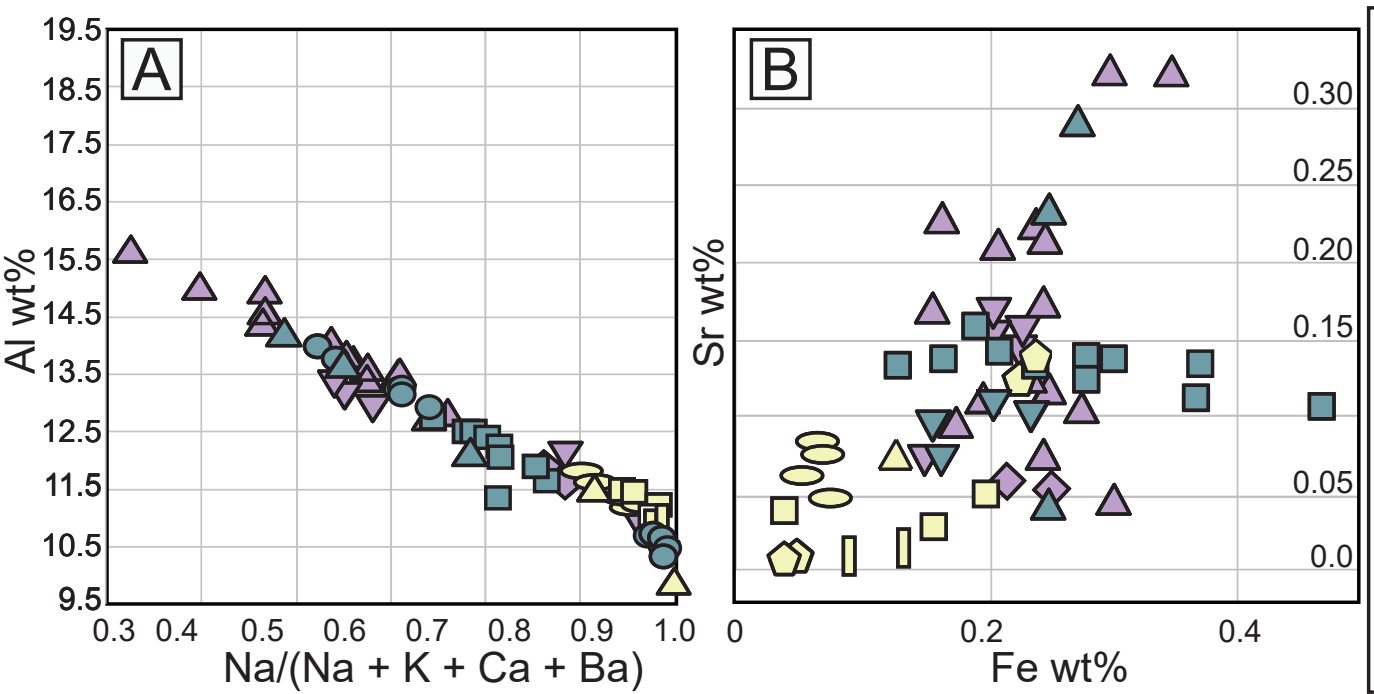

$\nabla$ Silver Bell

Sierrita $\diamond$ Tea Cup

Charleston

$\checkmark$ Ninetysix Hills

[ Sycamore Canyon

Central Mining

$\triangle$ district

$\square$ Eagle Pass $\square$ Ajo

Assemblage albite - chlorite - epidote

Na-plagioclase

- actinolite

Na-plagioclase

\pm garnet \pm pyroxene 
Figure 5
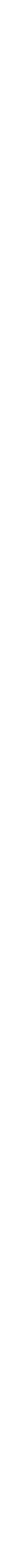

\section{$C$}

Charleston Sycamore Canyon $<$

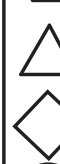
Ninetysix Hills Central mining district Tea Cup

Sierrita $\nabla$ Silver Bell Eagle Pass $\square$ Ajo

Assemblage $\square$ albite - chlorite - epidote Na-plagioclase - actinolite Na-plagioclase \pm garnet \pm pyroxene 

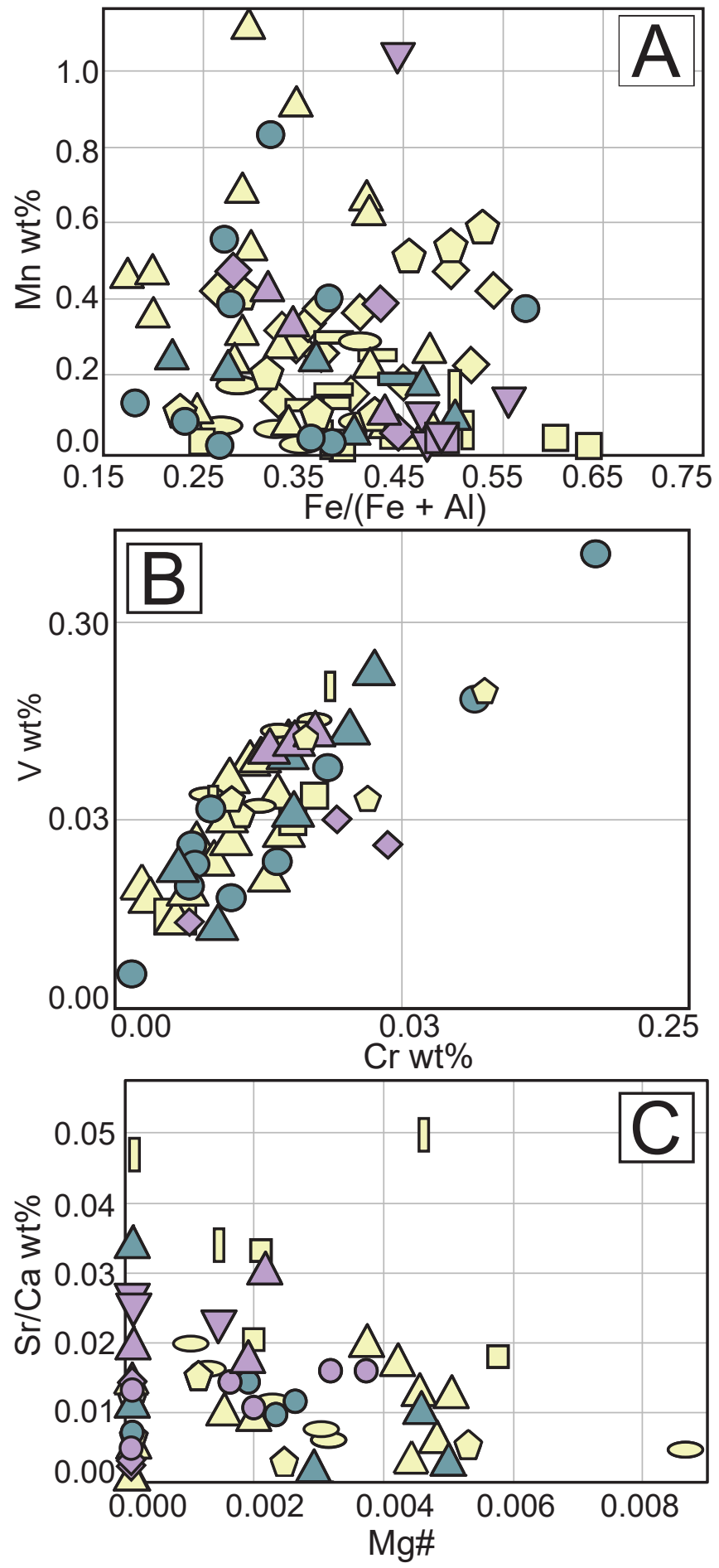

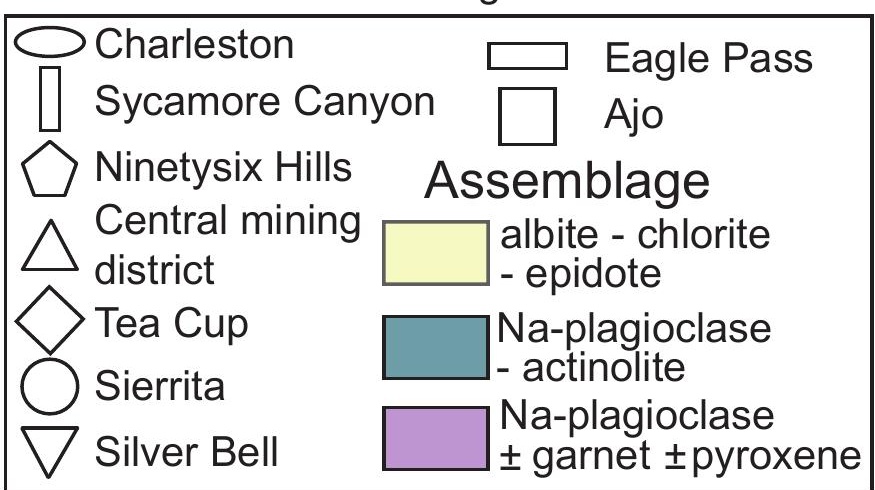




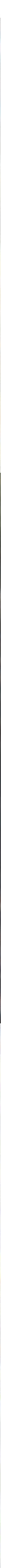

A

30
$\mathrm{C}$

\section{um}


Figure 8
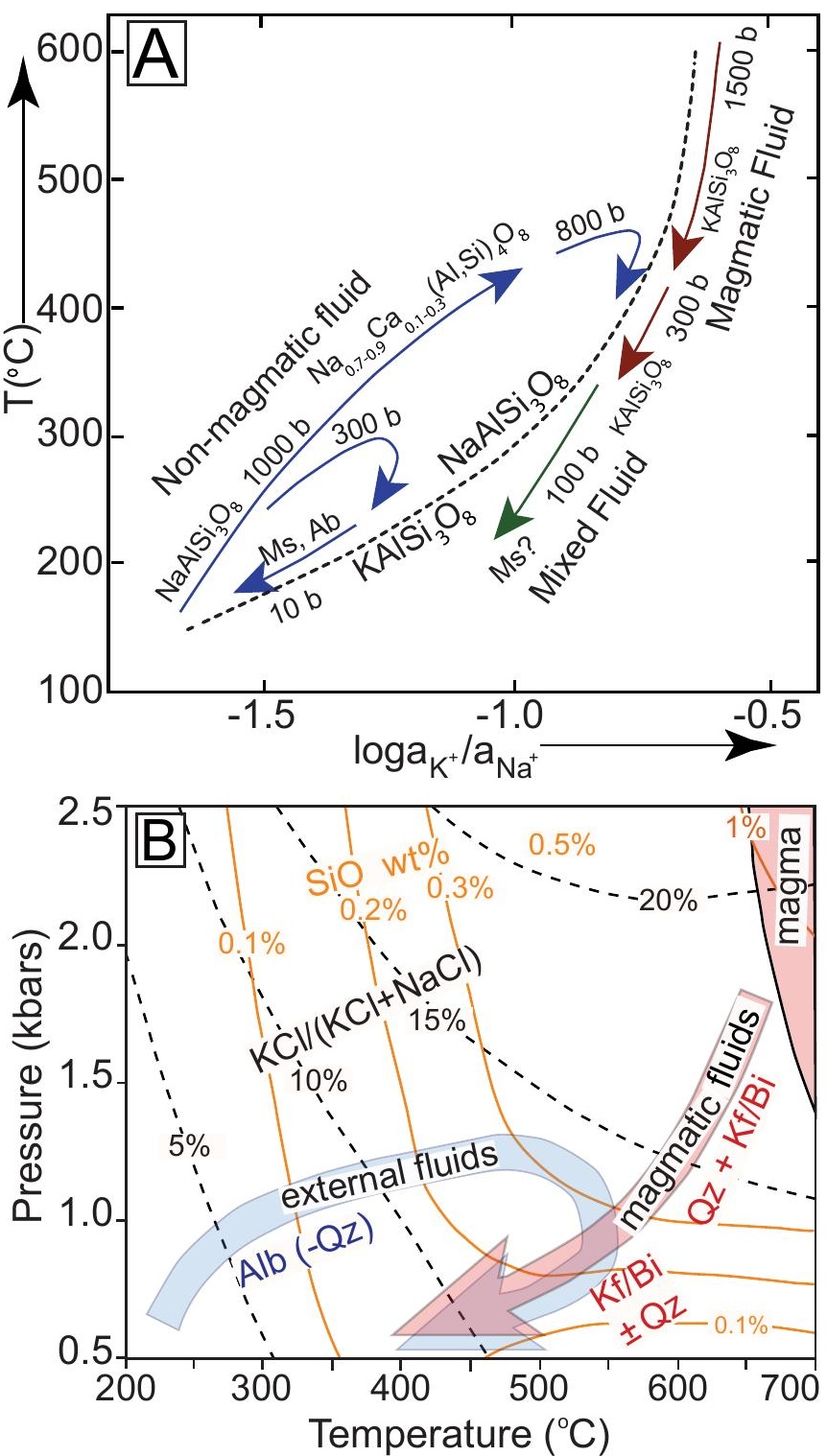
Figure 9

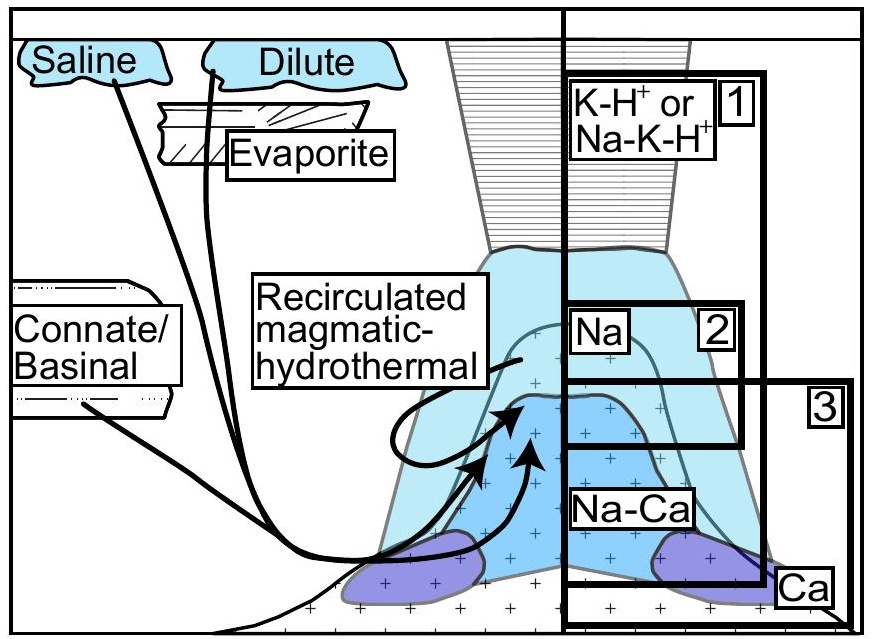

